\title{
تصميهم إستراتيجية قائمة علي الخرائط الذهنية وأثرها علي تنمية التحيل الدراسي وبعض المهارات الحياتية لدي طالبات الإقتصاد المنزلي بكليات التربية النوعية
}

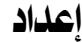

هـ مساح عبد الفتاح عبد الجواد أهمد مدرس إدارة المنزل والمؤسسات

كلية التربية النوعية - جامعة الزقازيق

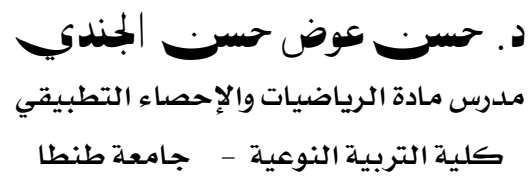

مجلة بحوث التربية النوعية ـ جامعة المنصورة

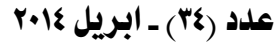




\title{
تصميم إستراتيمية قائمة علي الخرائط الذهنية وأثرها علي تنمية التصيل الدراسي وبهض المهارات الهياتية لدي طالبات الإقتصاد المنزلي بكات التربية النوفية
}

\author{
| (إعداد

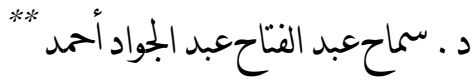

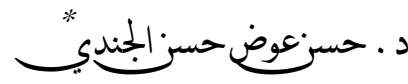

|ม่|l|

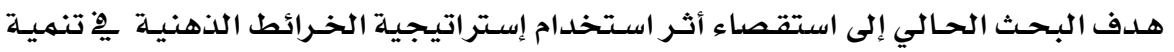

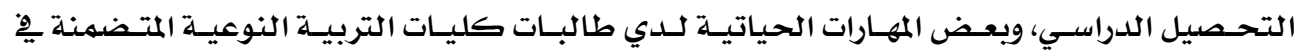
موضوعات مقرر التربية الأسريـة.

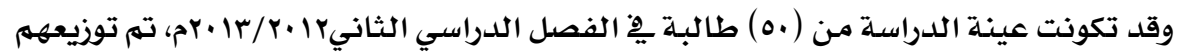

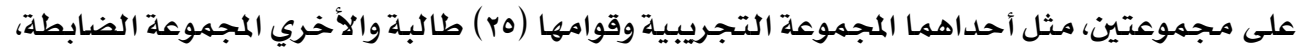

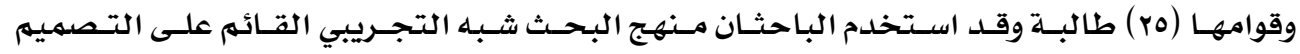

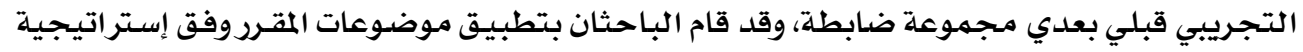

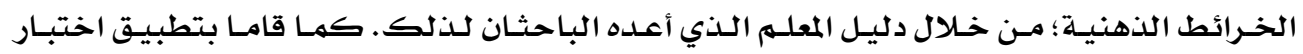

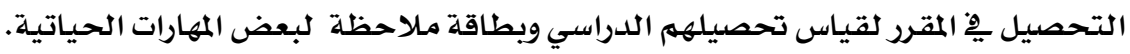

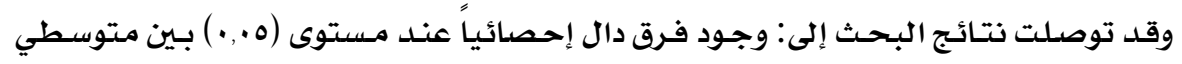

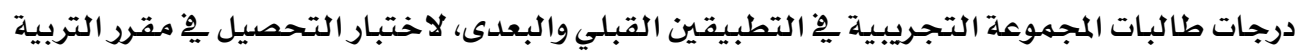

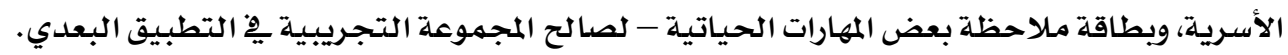

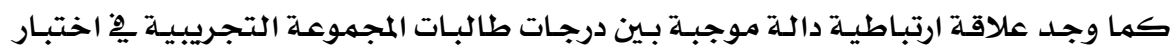
التحصيل ودرجاتهن علي بطاقة ملاحظة المهارات الحياتية.

وأوصي البحث القائمـين بعمليتي التعليهم والتعلم الاهتهـام بإستر اتيجية الخـرائط الذهنيـة، وعقد ورش عمل للتدريب علي استخدامها يِّ التدريس.

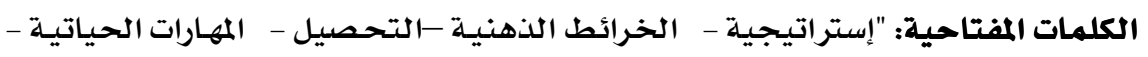

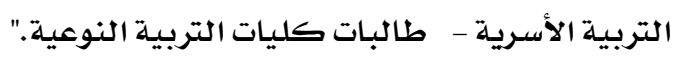

مدرس مادة الرياضيات والإحصاء التطبيقي كلية التربية النوعية - جامعة طنطا مدرس إدارة المنزل والمؤسسات كلية التربية النوعية - جامعة الزقازيق 
يشهد القرن الحادي والعشرون ثورة معلوماتية وتكنولوجية هائلة ِِّ جميـع مجـالات الحيـاة،

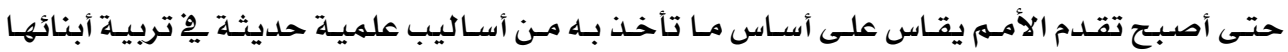

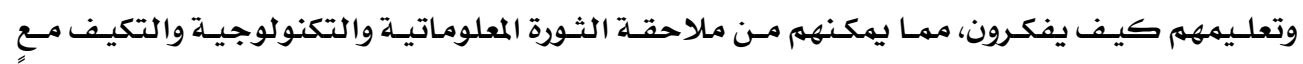

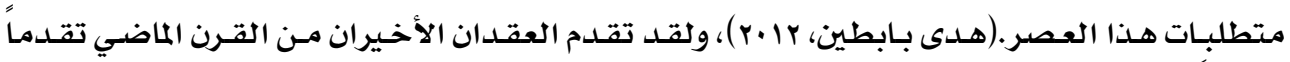

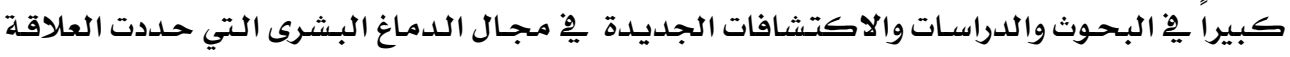

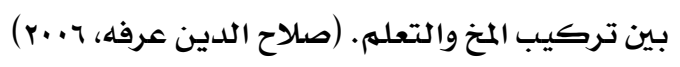

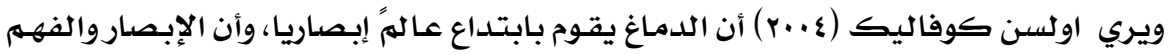

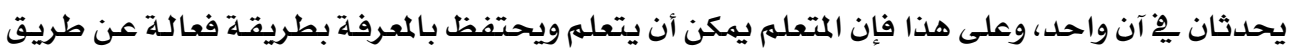

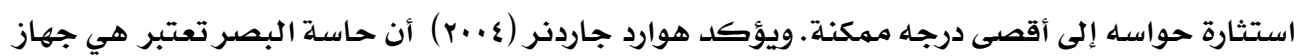

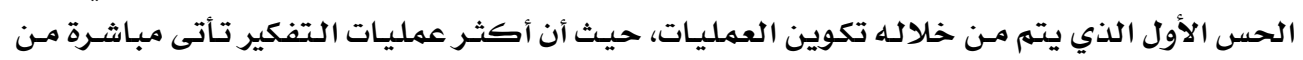

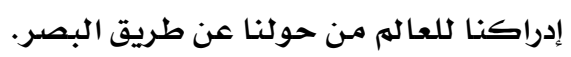

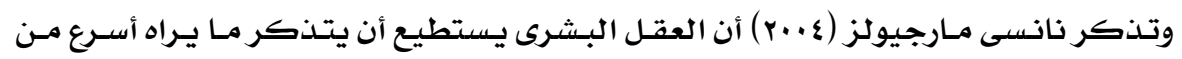

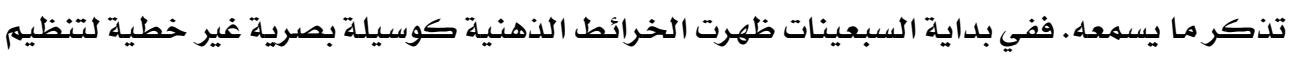

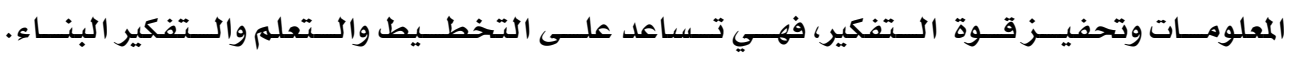
(Buzan,1977)

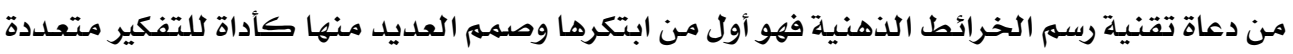
الأساليب لتقوية الذاكرة.

ففي الوقت الحاضـروفى الدـول المتقدمـة تستخلدم الخـرائط الذهنيـة مـن قبـل الملايـين مـن

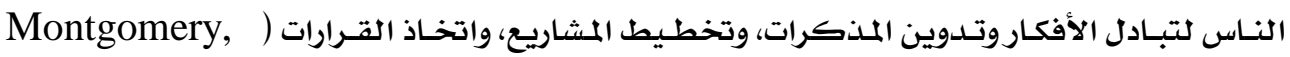

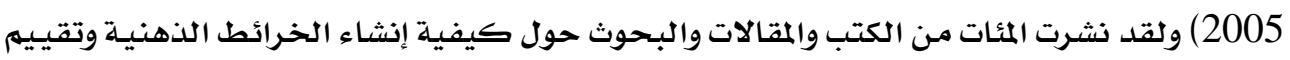

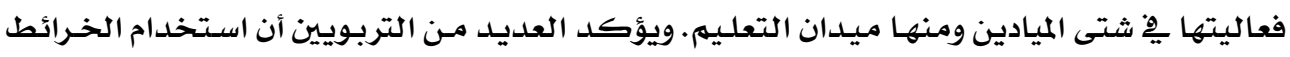

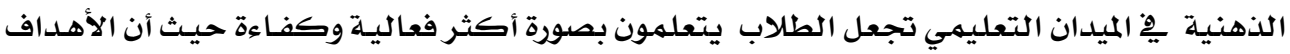

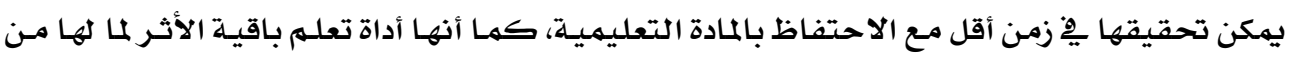

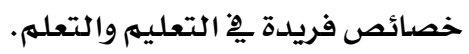

فضلا عن اسـتخدام المعلمـين للخـرائط والمخططـات والأشـكال للتمثثيل الخـارجي للمعرفة؛

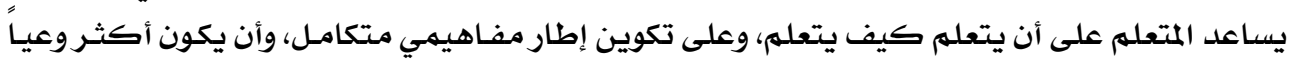

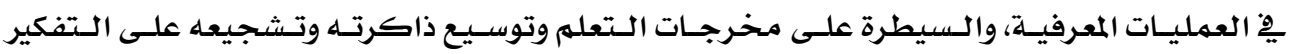

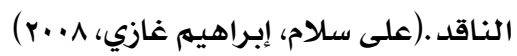

وهناك العديد من الجهود والتجارب التربوية العالمية والتي تعد مؤشرات بحثية من نجاحسات

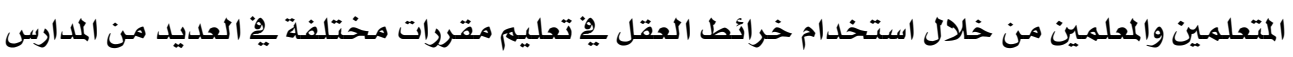

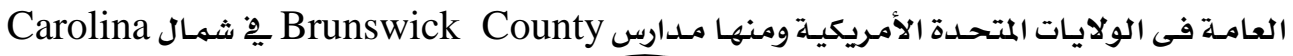




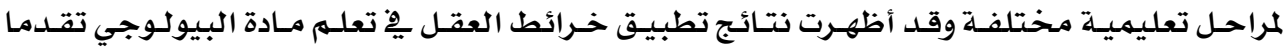

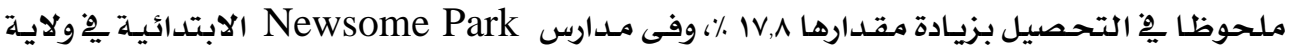
؛ Virginia

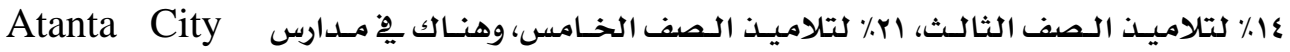

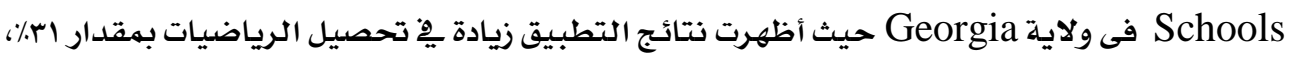

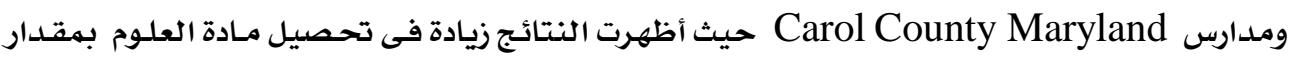
(Hyerle,D.,2004)). \%ı, r

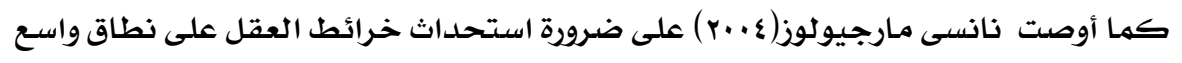

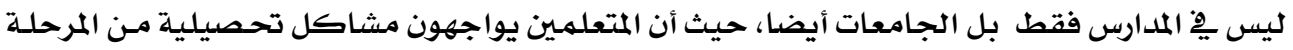
الابتدائية حتى المرحلة الجمامعية.

Farrand, P, Hussain, F, Hennessy, ) وهدفت دراسـة فاندراند وحسـين وهينسى المرحلهـ

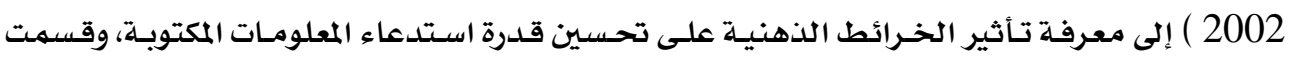

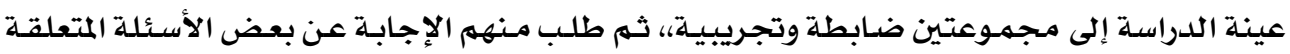

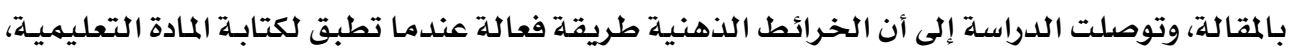

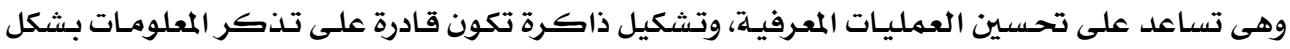
أفضل.

كما أكـدت العديد من الدراسات علي أهميـة الخـرائط الذهنيـة يِّ تنميـة المهارات الحياتيـة

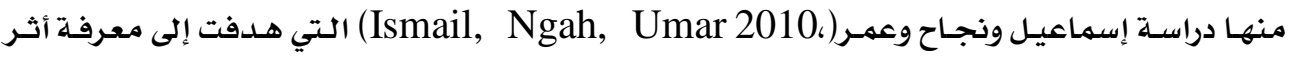

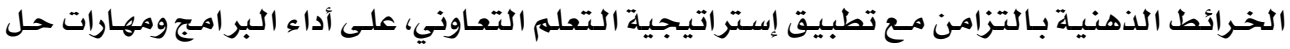

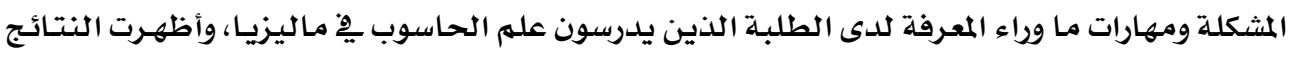

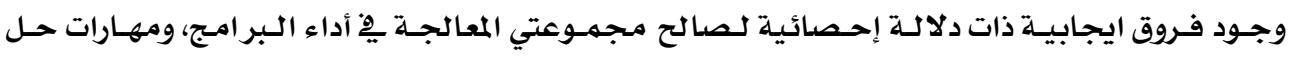

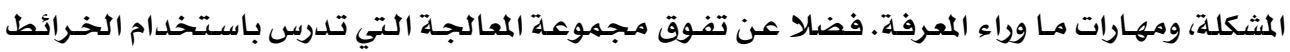

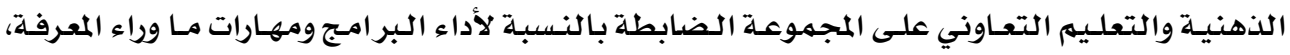

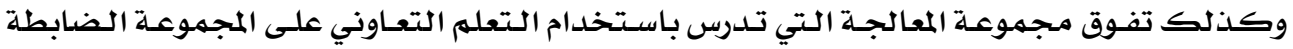

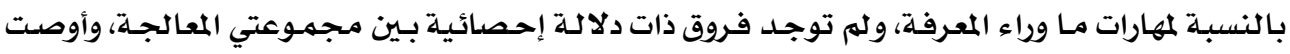

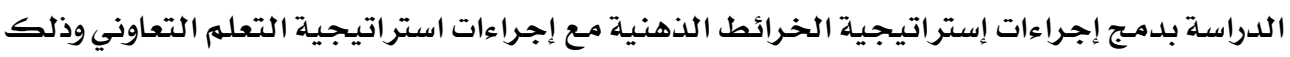

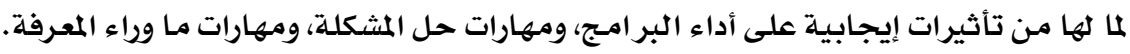

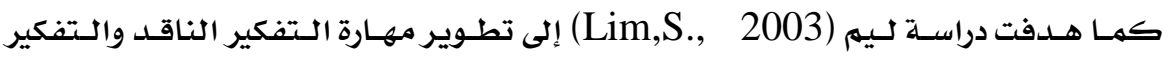

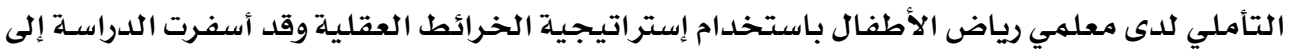

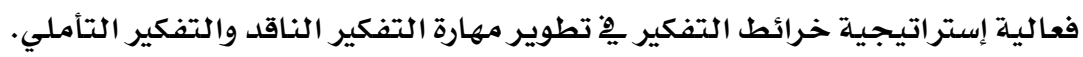


سب تصميه إستراتيجية قائمة علي الخرائط النهنية وأثرها علي تنهية التحصيل اللراسي ويعض المهارات الحياتية لـ

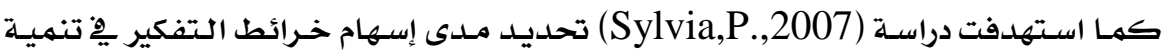

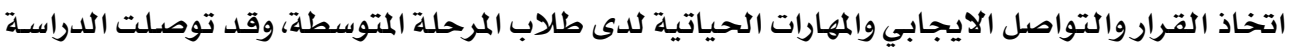

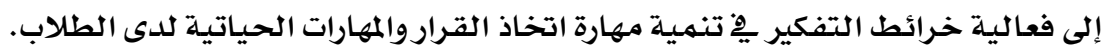

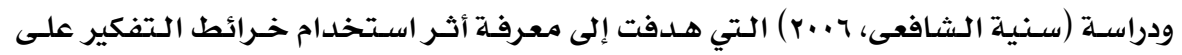

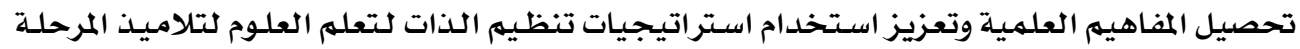

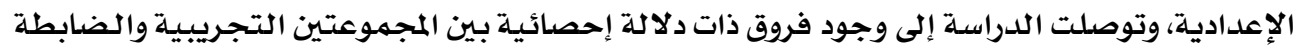

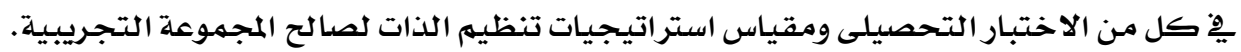

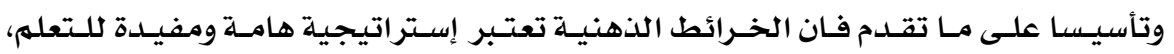

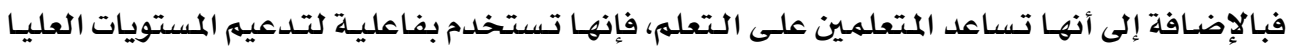

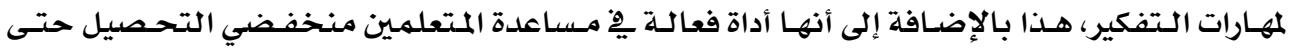

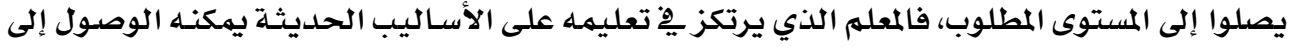

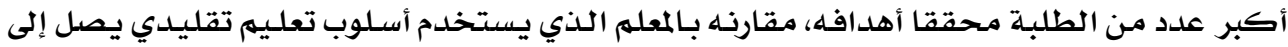

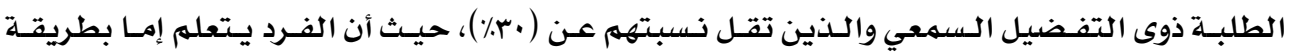

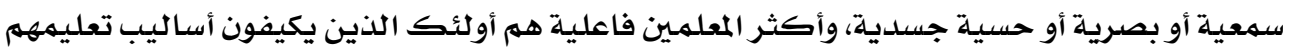

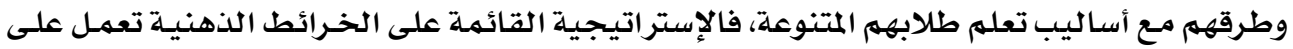

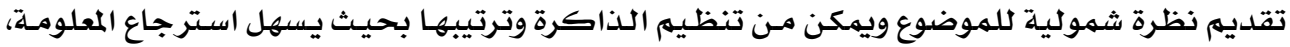

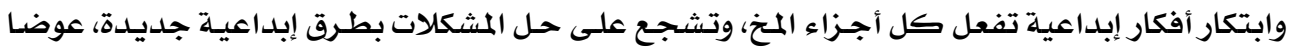
من الطريقة التقليدية يف التعليهم والتفكير.

\section{الإحساس بالإنكانة:}

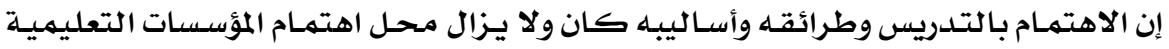

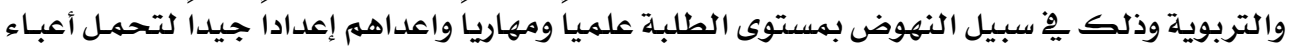

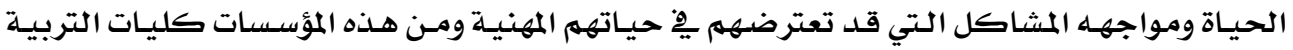

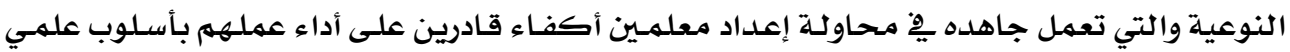
وتريوي للرقى بالعملية التعليمية. ومن أولى اهتماماتها بعد الناحية العلمية المعرفية توفير الأجهواء الملائمسة لتعلم أبنائها مـن

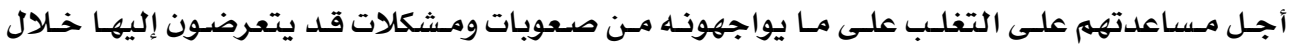

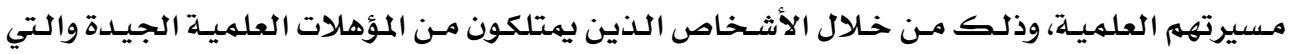

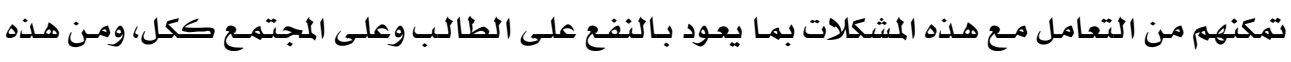
المشكلات ظاهرة ضعف التحصيل الدراسي وافتقار المهارات الحياتية لديهم.

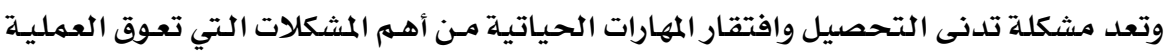

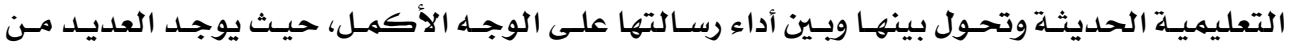

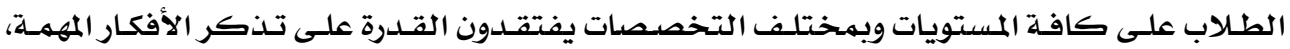


وتنظيمها ومعالجتها وتنظيم تعلمها ذاتيا عند دراستهم لموضوع ما، فضلا عن افتقارهم معظم المهارات

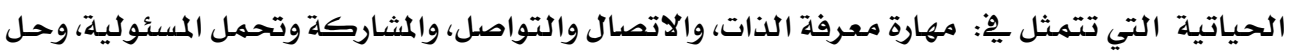

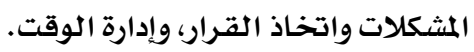

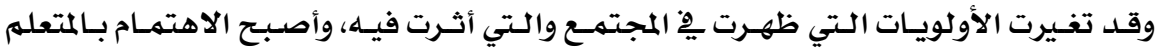

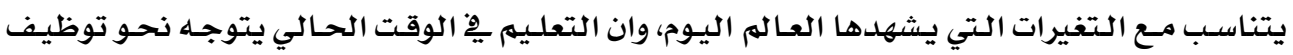

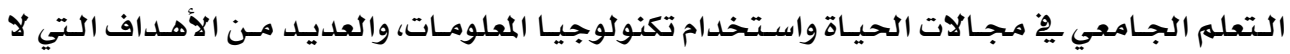

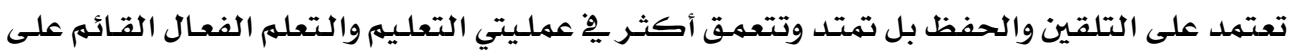

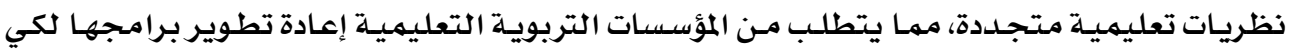

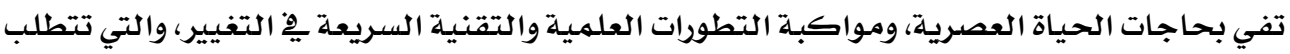
تعليما من نوع جديد يِّ كل مـراحل وأنواع التعليهم. ولطبيعة مقررات كليات التربية النوعية التي تتميز بوجـود بعض المواد المشتركة والمكثفـة

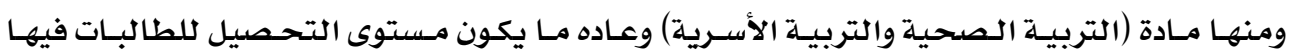

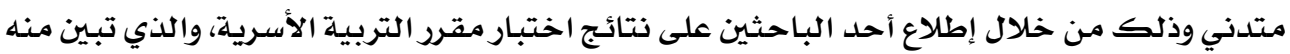
انخفاض ملحوظ يِّ مستوى تحصيل الطالبات ِِّ الأعوام الثلاث الأخيرة.

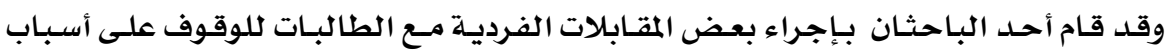

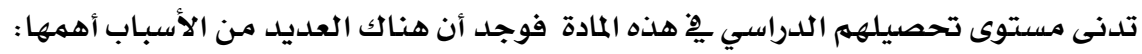

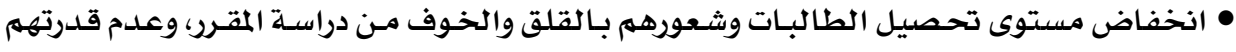

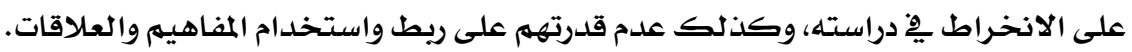

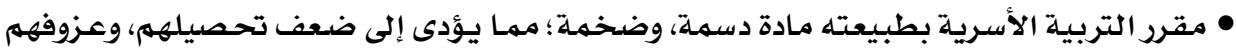

$$
\text { عن دراستها. }
$$

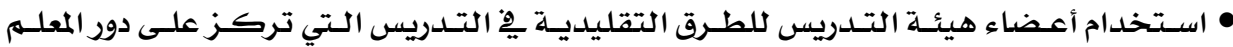

$$
\text { وتقليص دور المتعله. }
$$

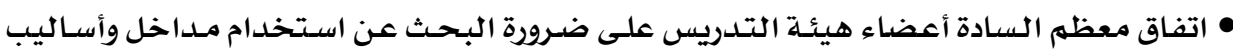

$$
\text { تدريس حديثة لتدريس التربية الأسرية. }
$$

ولما ككان تكـوين المهارات الحياتيـة عنــ الطالبـات لـيس أقل أهميـة مـن اسـتيعابهم للهـادة

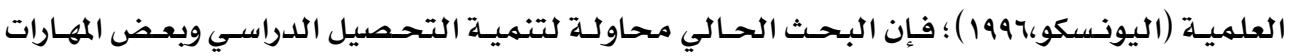
الحياتية.

وانطلاقاً مما سبق، وِيْ ضوء الاتجاهات الحديثة لتعليم وتعلم التربية الأسرية والتي تؤكد

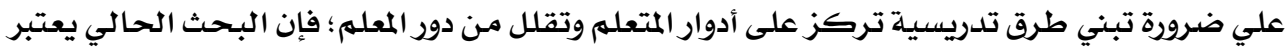

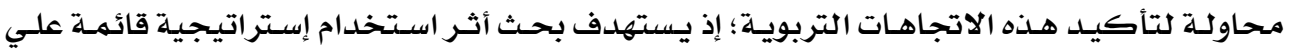

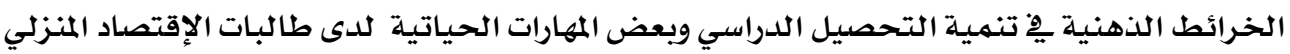
بكلية التربية النوعية وبقاء أثر تعلمهيهم. 


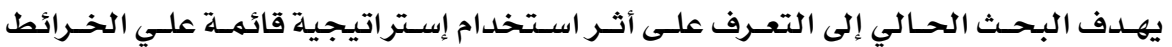

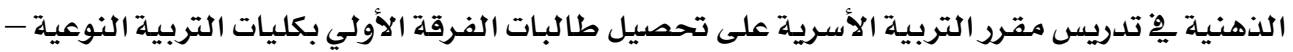

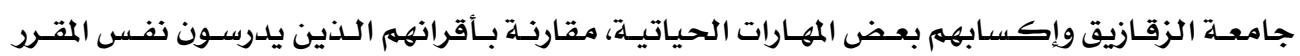
بالطريقة المعتادة وذلك من خلال الأهداف الفرعية التالية:

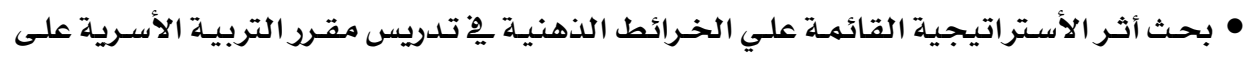

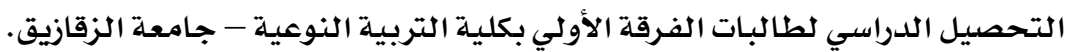

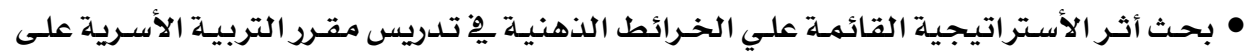

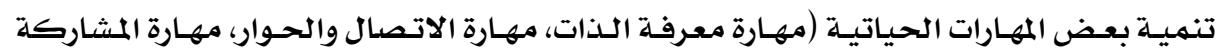

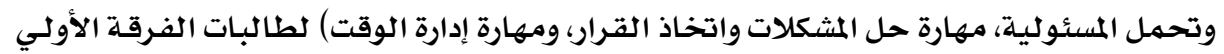
بكليات التربية النوعية - جامعة الزملة الزقازيق.

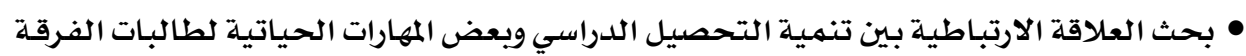

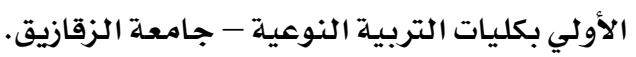
مشكلة البحث وأسئلتهه:

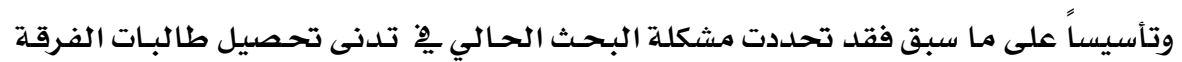

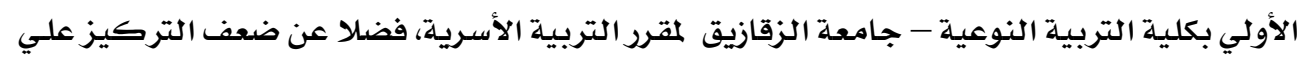

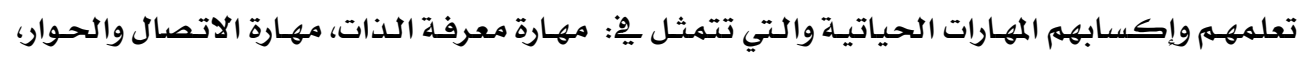

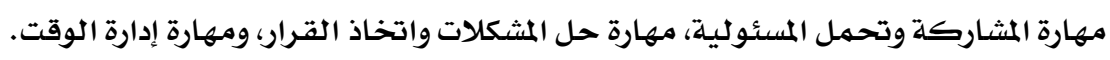

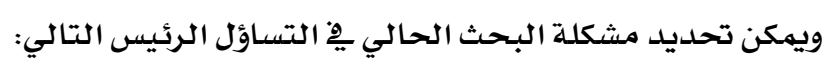

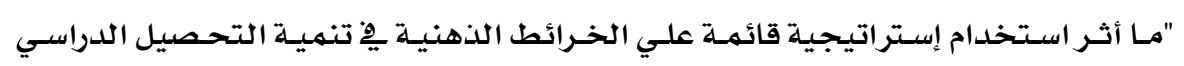

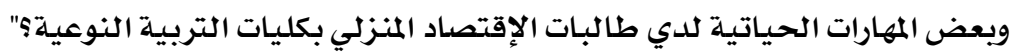
وينبثق من هذا التساؤل الرئيس الأسئلة الفرعية التالية:

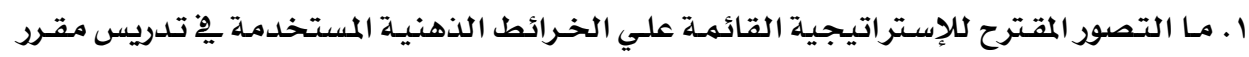

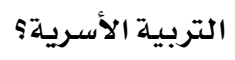

r . ما أثر استخدام إستراتيجية قائمة علي الخرائط الذهنية يِّ تدريس مقرد التربية الأسرية علي

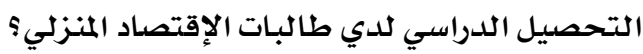

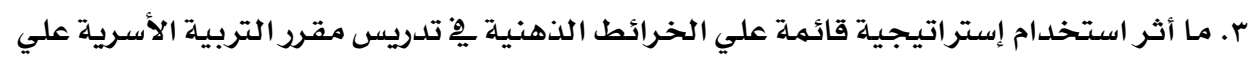

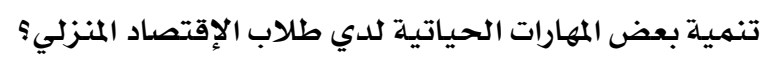

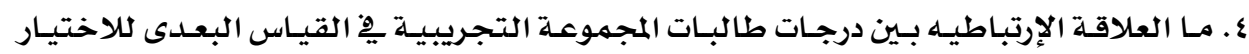
التحصيلى وبطاقة ملاحظة لبعض المهارات الحياتية. 


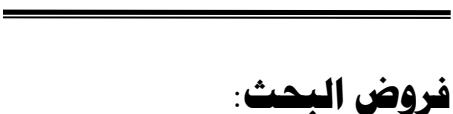

يسعى البحث الحالي للإجابة عن التساؤلات و التحقق من الفروض التالية:

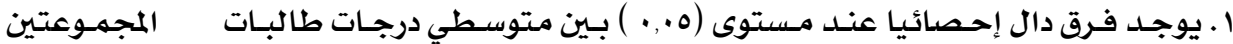

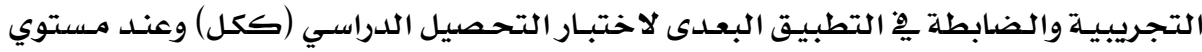

(التذكر، الفهم، التطبيق، التحليل).

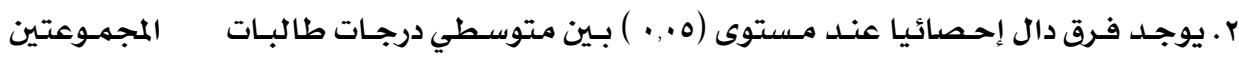

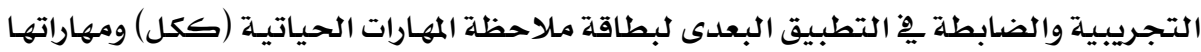

$$
\text { الفرعية. }
$$

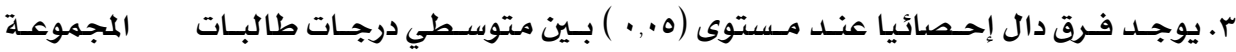

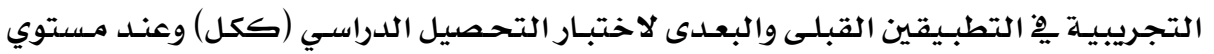

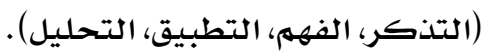

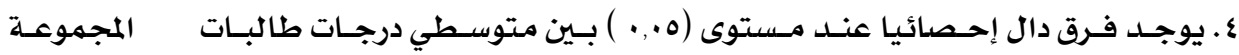

التجريبية يِّ التطبيقين القبلي والبعدى لبطاقة ملاحظة المهارات الحياتيـة (ككل) ومهاراتها

$$
\text { الفرعية. }
$$

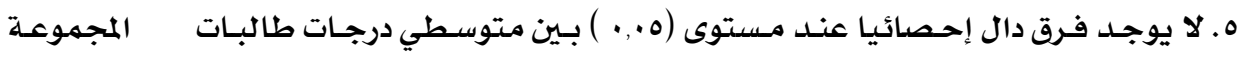

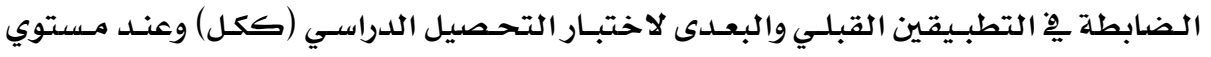

$$
\text { (التذكر، الفهم، التطبيق، التحليل). }
$$

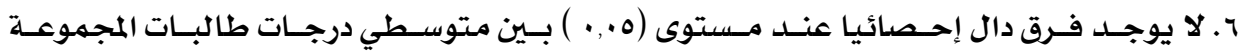

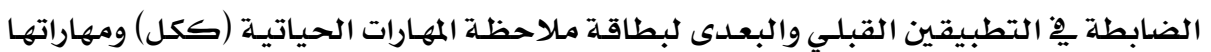

$$
\text { الفرعية. }
$$

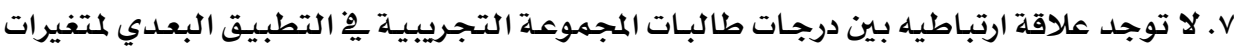

$$
\text { البحث (التحصيل الدراسي، المهارات الحياتية). }
$$

$$
\text { تتلخص أهمية البحث الحالي: }
$$

• مسايرة الإتجاهات العالمية الحديثة يِّ تدريس مقررات الإقتصاد المنزلي بوجها عام ومقرر التربية

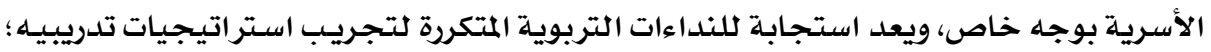

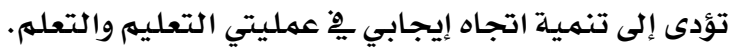

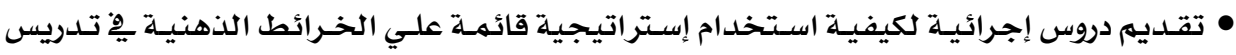

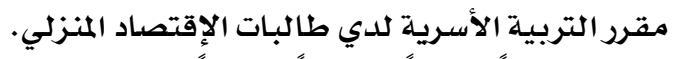

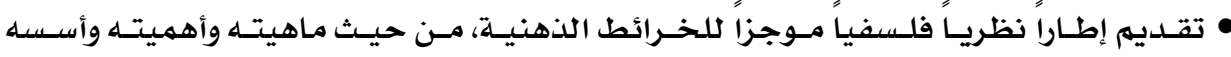
ومراحله وإجراءاته، وأدوار ومهام كل من المعله، والطالبات فيله. 


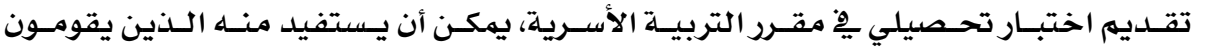

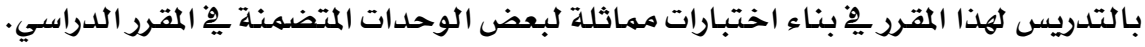

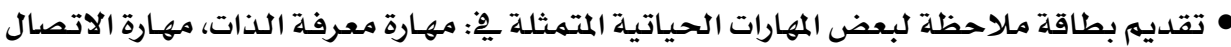

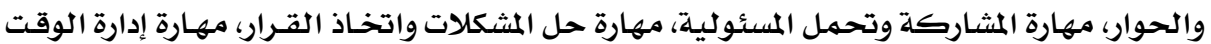

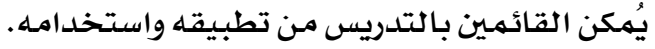

\section{هصطات البحث العلمية والمفاهيم الإجرائية:}

• الخرائط الذهنية

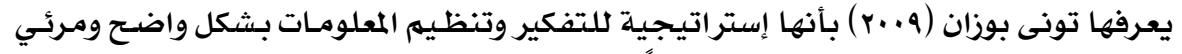

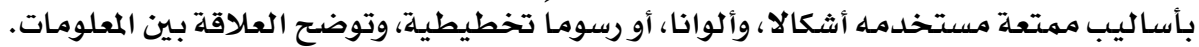

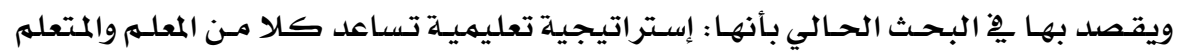

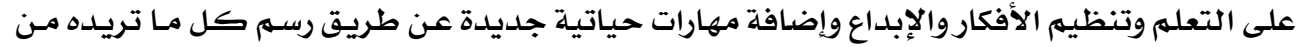

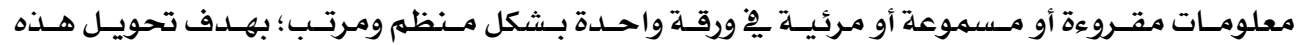

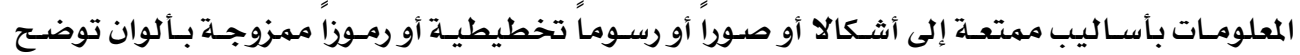

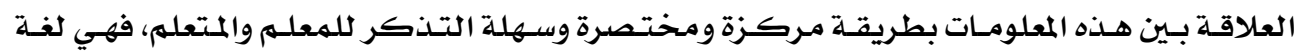

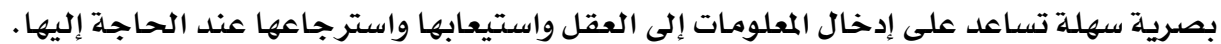

\section{• إستراتيجية الخرائط الذهنية}

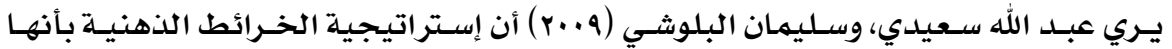

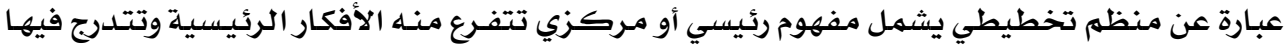

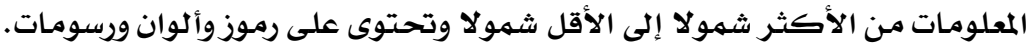
ويقصد بها يُ البحـث الحسالي بأنها: مجموعـة الخطـوات والآداءات التدريسية التي يتبعها المعلهم أثناء تدريس مقرر التربية الأسرية وذلك لتحقيق الأهداف التربوية المنشودة. • التحصيل الدراسي:

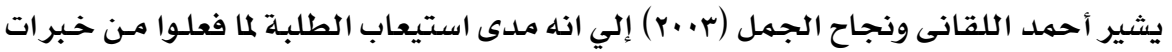

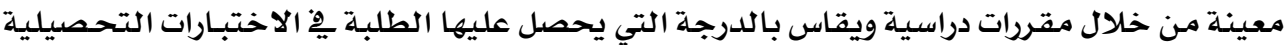

ويقصد بها يِّ البـحث الحـالي بأنها : مـدى استيعاب طالبـات الفرقـة الأولي شعبـة الإقتصاد

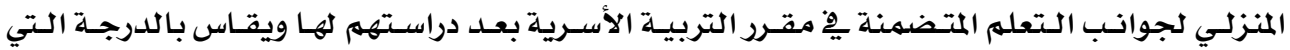
تحصل عليها الطالبة يِ الاختبار التحصيلى المعد لهذا الغرض ويتميز بالصدق والموضوعية.

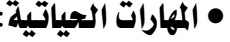

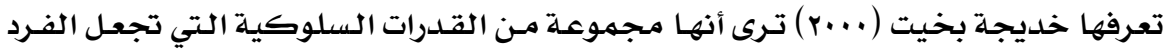

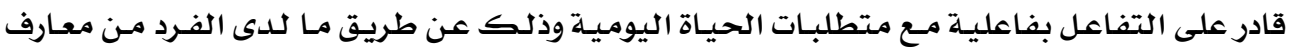


$\underline{\underline{ }}$

ومعلومات ومهارات واتجاهات وقيهم يقوم بتوظيفها لكي يتعامل بإيجابية مـع الحياة اليوميـة ومـتغيرات

العصر.

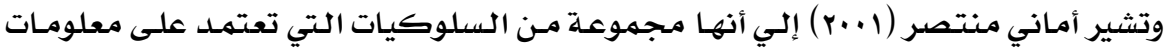

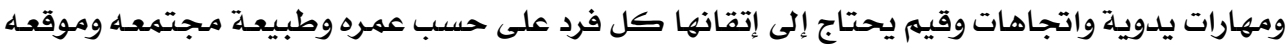

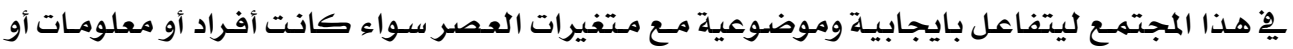
مواقف أو مشكلات.

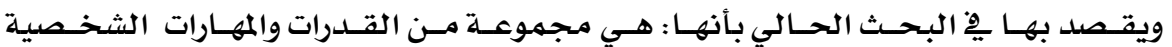

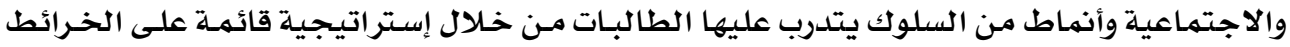

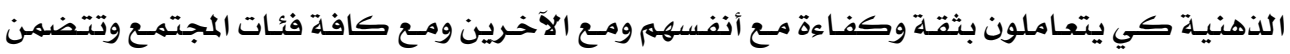

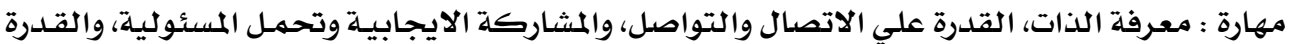

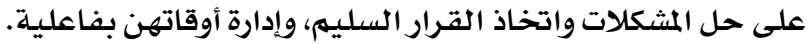

هدود البمث:

$$
\text { اقتصر البحث الحالي علي الحدود التالية: }
$$

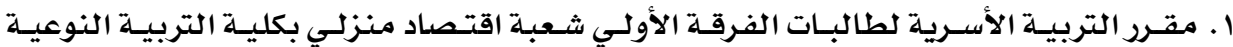

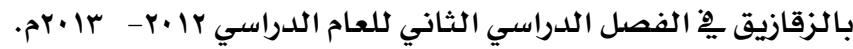

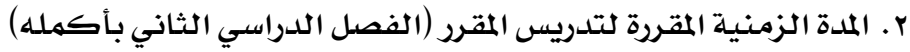

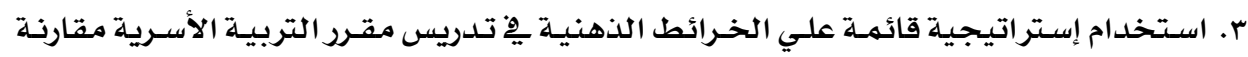

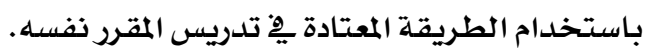

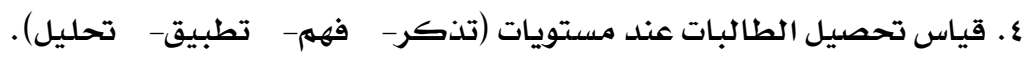

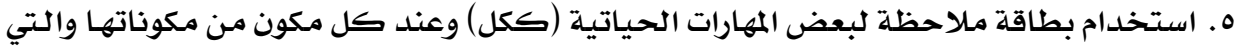

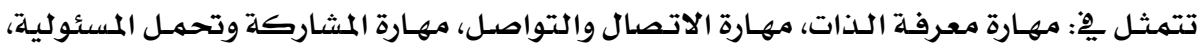

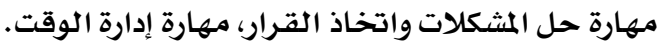

تم اختيار عينـة مـن كليـة التربيـة النوعيـة بجامعـة الزقازيق خـلال الفصل الدراسي الثاني

\begin{tabular}{|c|c|c|}
\hline 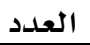 & نوع التعلهم & المجموعة \\
\hline ro & إستر اتيـجية الخرائط الذهنية & التجريبيية \\
\hline ro & الطريقة المعتادة & الضابطة \\
\hline
\end{tabular}

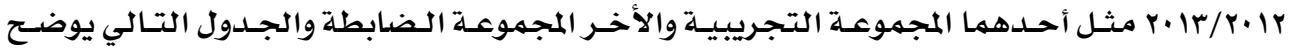
توزيع أفراد عينـة الدراسـة: مئل احساه

جدول (1) توزيـ أفراد عينة البحث 
• اختبار تحصيلي يِّ مقرر التربية الأسريـة (من إعداد الباحثان).

• بطاقة ملاحظة لبعض المهارات الحياتية.(من إعداد الباحثان).

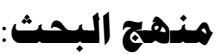

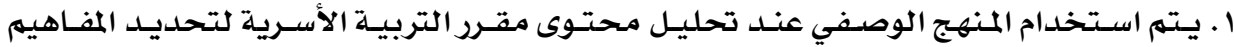

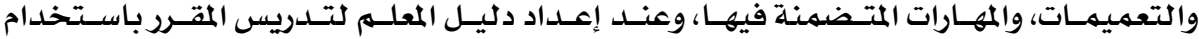

إستراتيجية الخرائط الذهنية وعند تحليل نتائج البحث وتفسيرها.

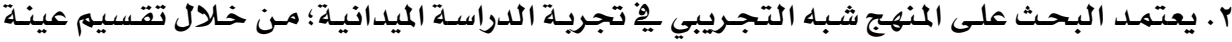

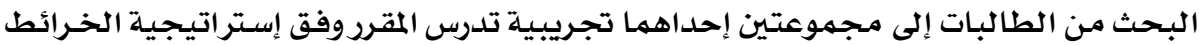

الذهنية، والأخرى ضابطة تلدرس نفس المقرر بالطريقة المعتادة.

ويشتمل التصميه التجريبي للبحث على المتغيرات التالية:

• المتغير المستقل: إستراتيجية قائمة علي الخرائط الذهنية.

• المتغير التابع: التحصيل وبطاقة ملاحظة لبعض المهارات الحياتية.

وقد استخدم الباحثان التصميهم التجريبي قبلي بعدى مجموعة ضابطة التالي:

Pre test - Post test - control group design

- G1 Pr1 .... x1 ..... Pt1

- G2 Pr2 .........Pt2

\section{الإطار النظري والدراسات السابقة:}

تؤكـد معظـم الاتجاهـات التربويـة المعاصـرة على أن اسـتراتيجيات التـدريس وأسـاليبه تؤثر

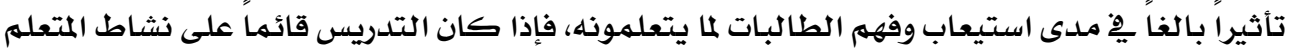

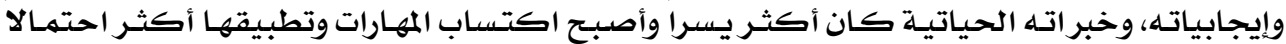
وكان هذا دافعا قويا لتقدمهم ِِّ بقية العلوم والمراحل الأخرى.

Mind Mapping أولاً: الخرائط الذهنية

ماهية الخرائط الذهنية والنظريات المستندة عليها:

ظهر مصطلح " الخريطة الذهنية" أو Mind Mapping لأول مرة عن طريق "تونى بوزان"

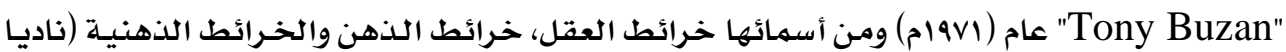

$$
\text { (r..v، السلطى) }
$$

وعرفها محمد هلال (r.VV) بأنها إستراتيجية تعليمية فعالة، تقوم بريط المعلومـات المقروءة

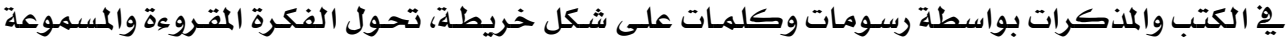

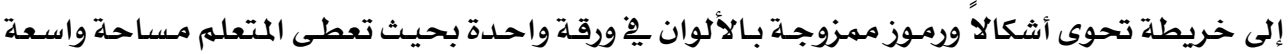


من التفكير والإبداع. كمها عُرفت بأنها نوع من أنـواع العمليـات المعرفيـة التي ظهرت مـن خـلال سلسلـة

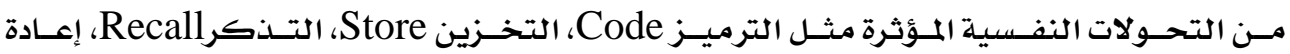

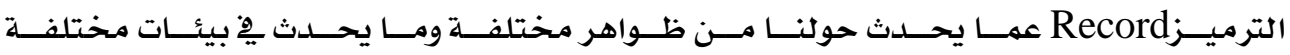

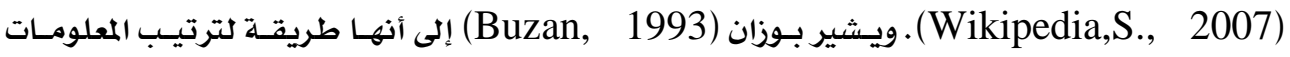
وتمثليها على شكل أقرب للذهن. الخرائط الذهنية ونصفا الدماغ الأيمن والأيسر:

أثـارت العديد من الدراسات إلى كيفية عمل العقل البشرى وإمكانات الإستفادة واستغلالال

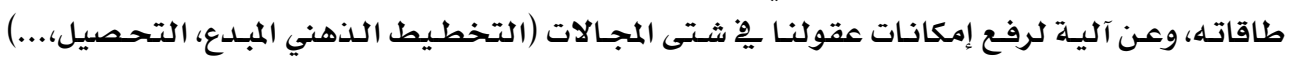

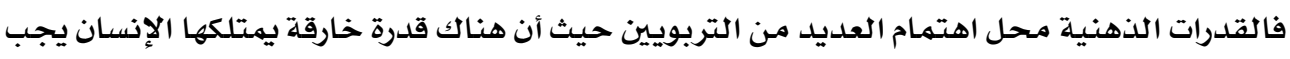

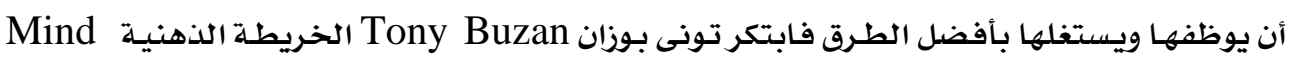

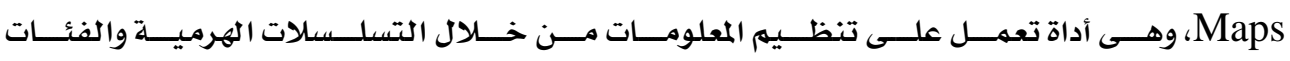

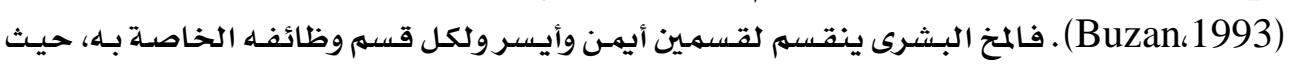

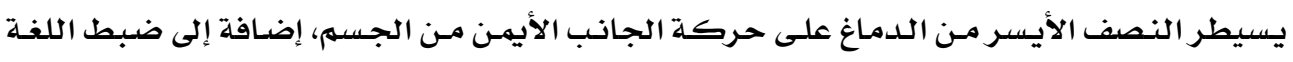

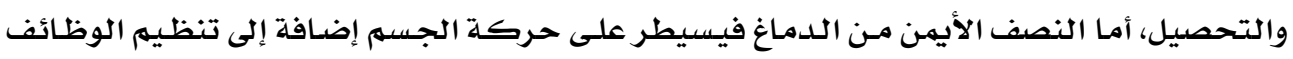

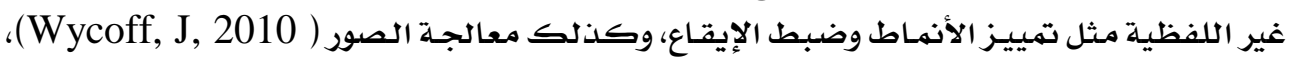

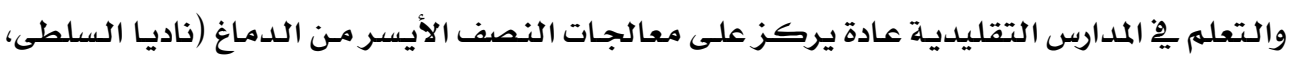

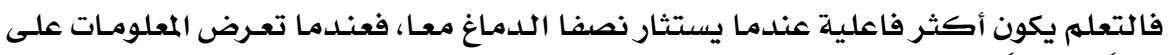

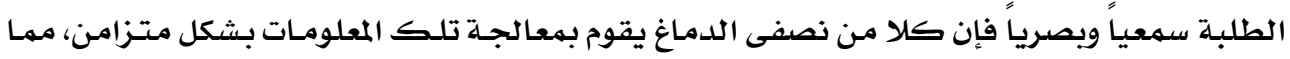

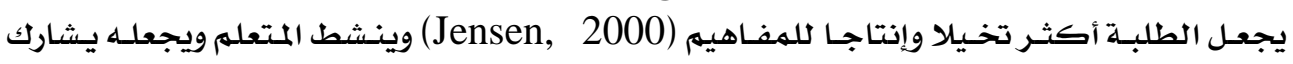

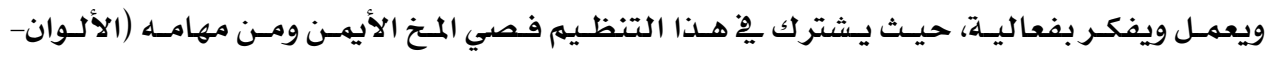

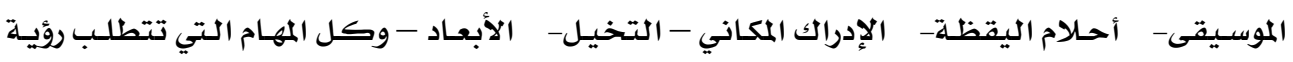

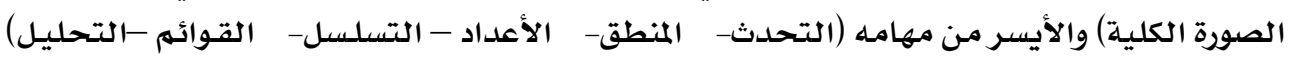

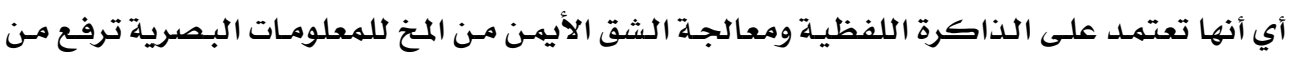

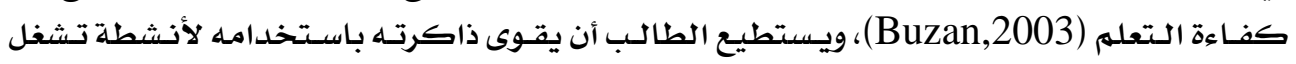

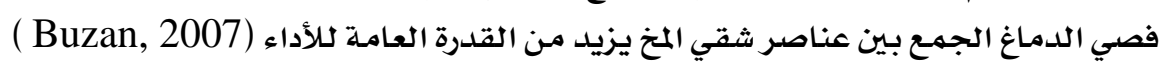

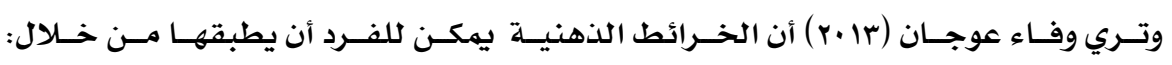

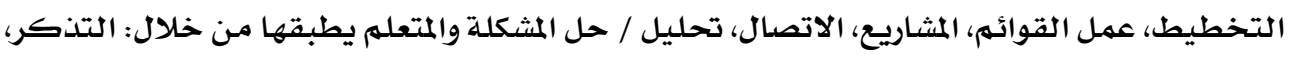

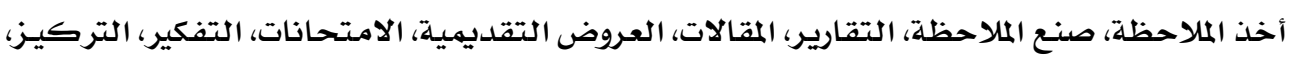

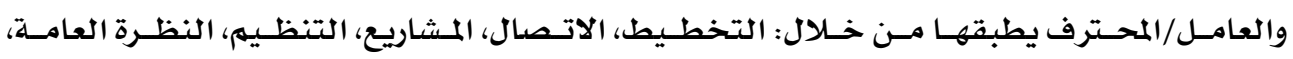

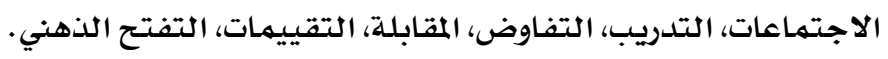




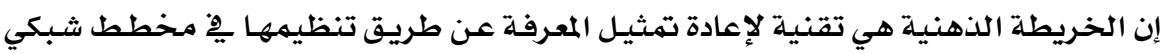

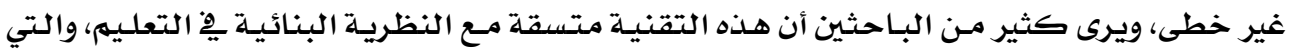

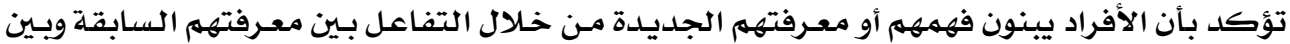

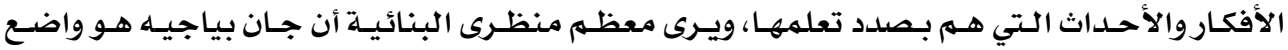

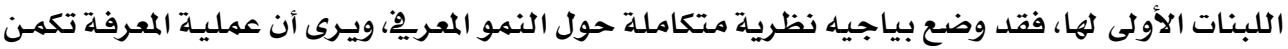

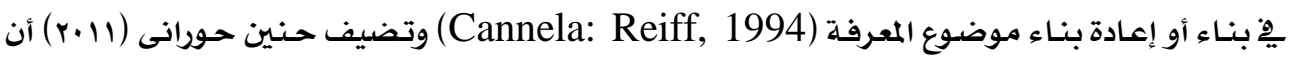

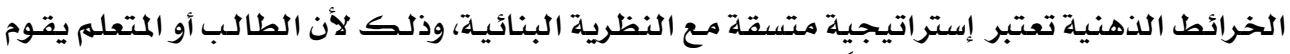

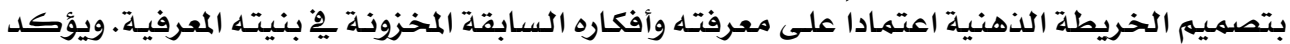

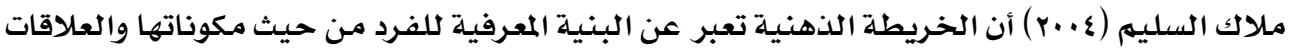
بين هذه المكونات.

ويمكن للمعلم تطبيق النظرية البنائية باستخدام إستراتيجية الخرائط الذهنيـة عن طريق

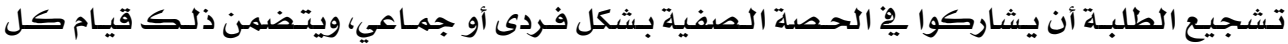

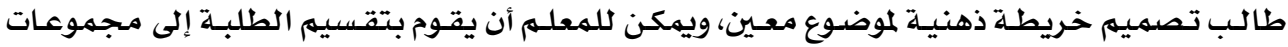

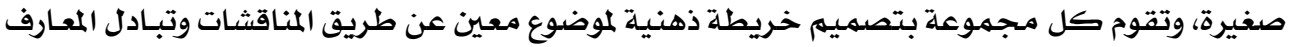
وسنحصل أيضا على خرائط ذهنية مميزة لخبر ات وأفكار أكثر من بنهية طالب. • نظرية أوزيل:

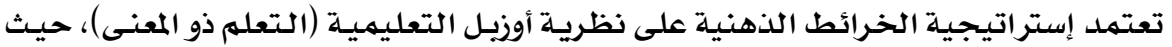

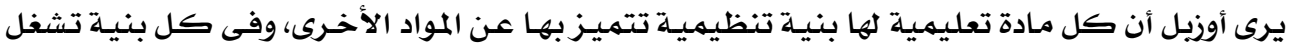

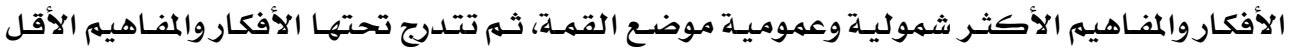

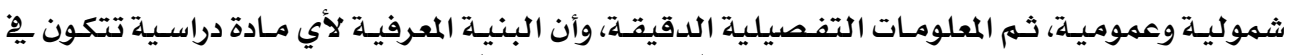

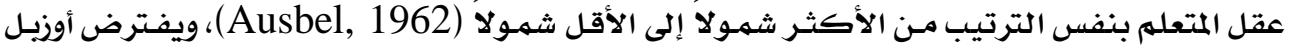

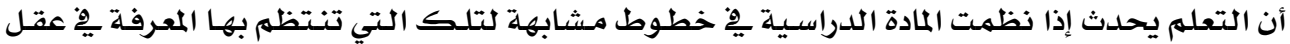

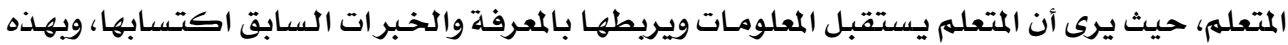

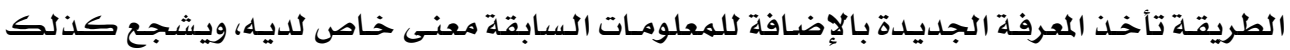

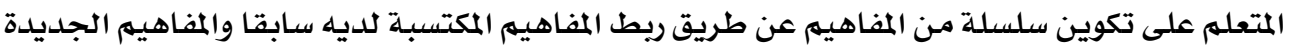

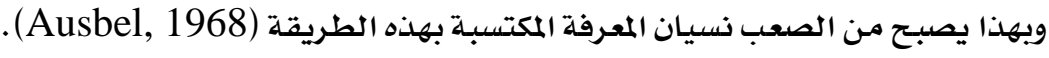

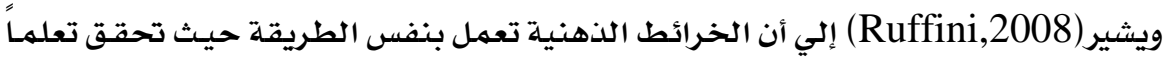

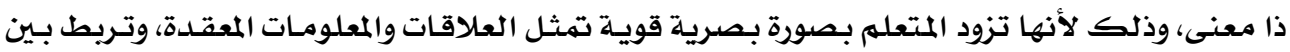

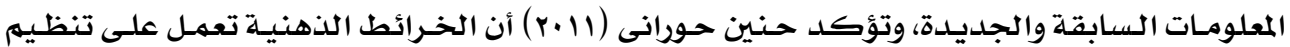


مجلة بحوث التربية النوعية - علد \&r - أبريل \& ا.r

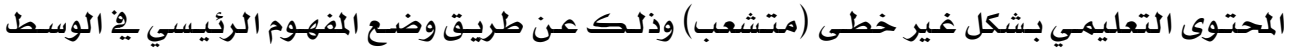

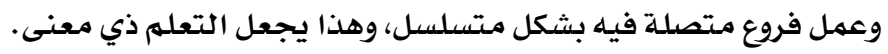

أهمية الخرائط الذهنية:

تتعـدد أهميـة اسـتخدام الخـرائط الذهنيـة يِّ الجوانب التربويـة والتعليميـة حيث تلعسب دوراً مهما من خلال ما يلي:

ا ـ تساعد المتعلمـين على تنظيهم وفهـم المعلومـات وعرض الأفكار بطريقـة سهلة وميسـرة ومفهومـة

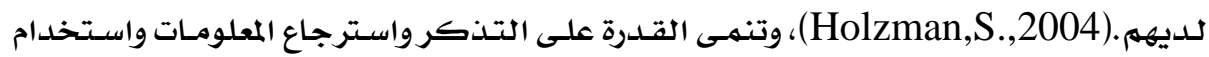

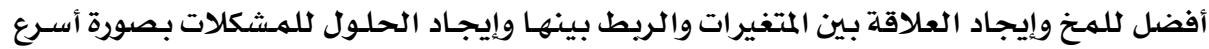

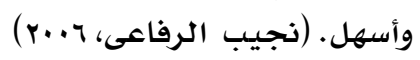

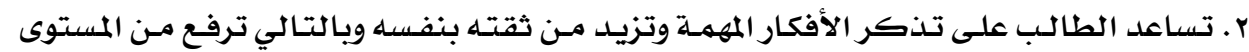

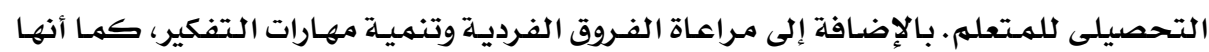

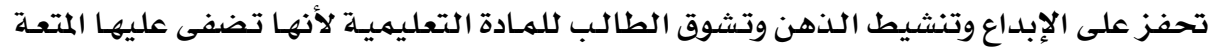

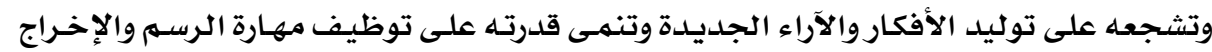

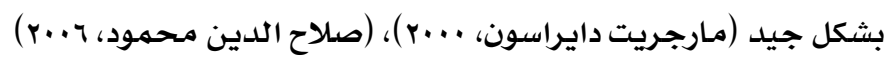

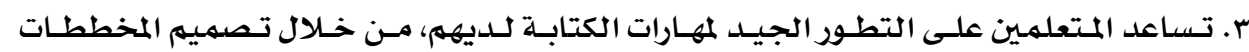

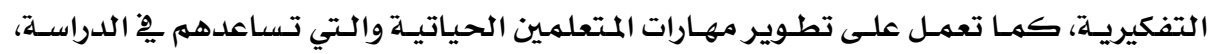

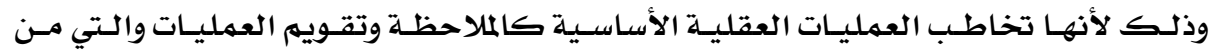

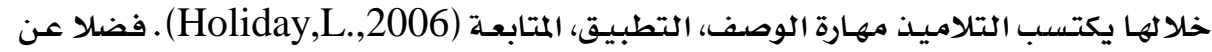

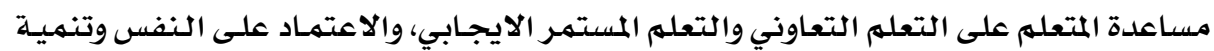

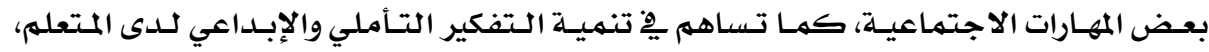

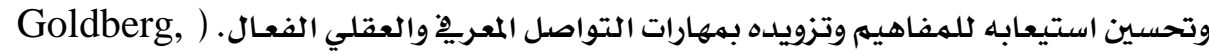

(C.,2004

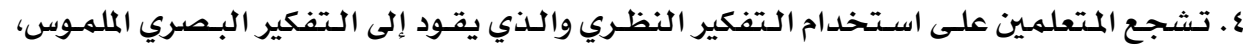

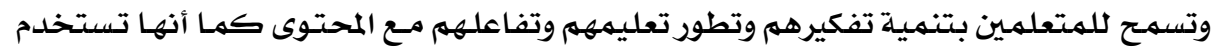

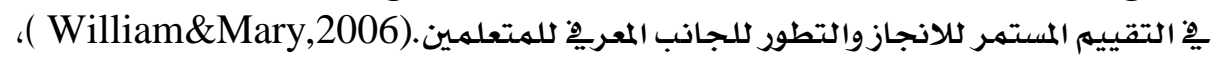

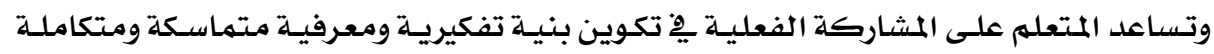

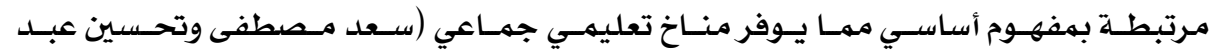

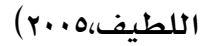

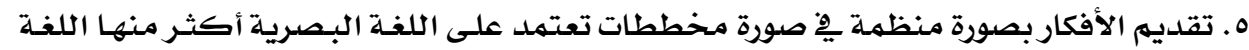

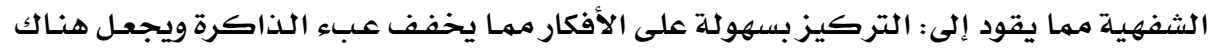

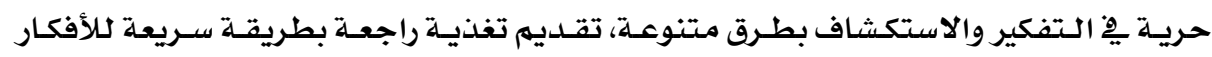

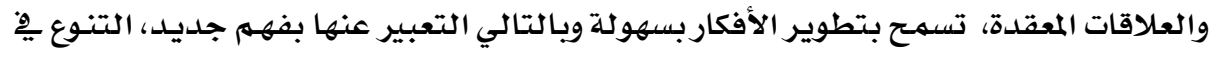


ב- تصميه إستراتيجية قائمة علي الخرائط النهنية وأثرها علي تنهية التحصيل الدراسي وبعض المهارات الحياتية لـ

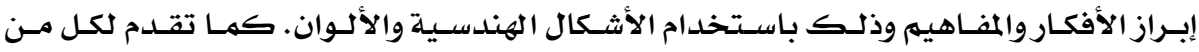

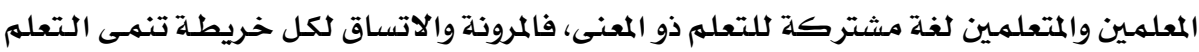

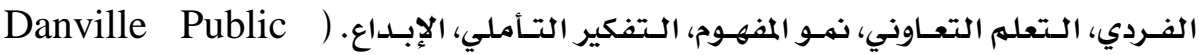

(School District,2004

أنواع الخرائط الذهنية:

يقدم هولزمـان(Holzman,2004) و مـاركس وفلنتزز(Margulies,\&Vlentza,2005)

$$
\text { عدة أنواع من الخرائط الذهنية ومنها: }
$$

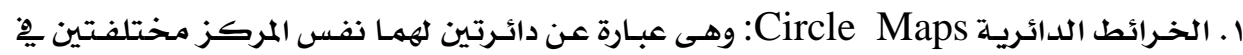

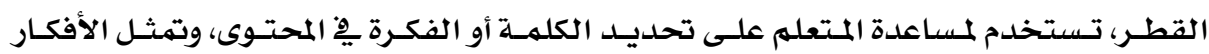

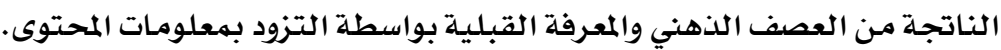

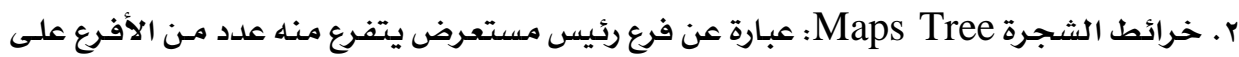

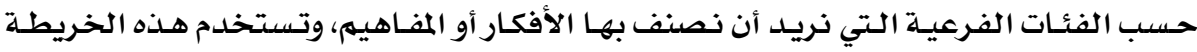

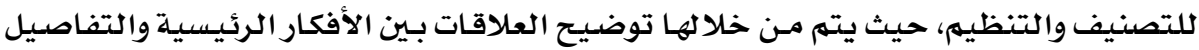

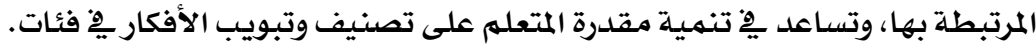

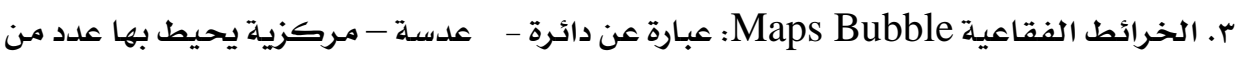

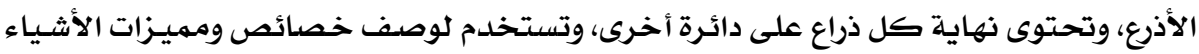

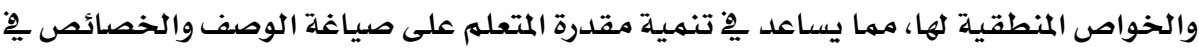
كلمات.

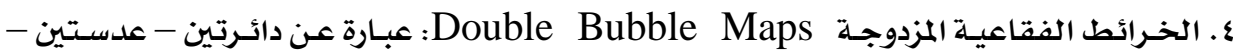

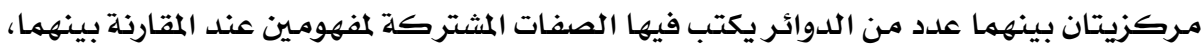

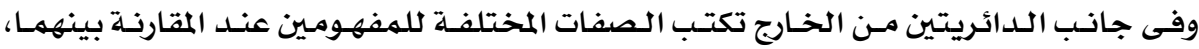

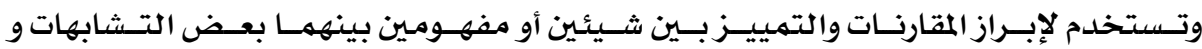

الاختلافات

ه. خـرائط التدفق المتسلسلة Maps Flow : هي عبـارة عن مجموعة مـن المستطيلات المتتاليـة،

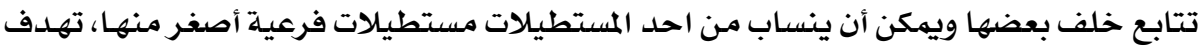

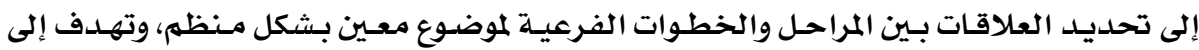

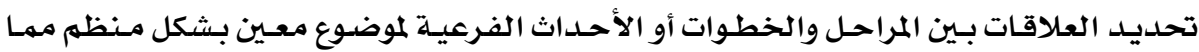

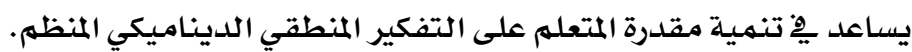

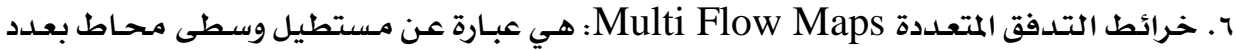

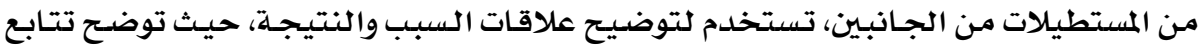

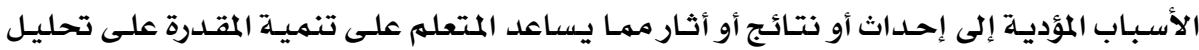
المواقف من خلال الأسباب والنتائج. 
V. الخرائط الدعامية Brace Maps : وهى تشبه قوس المحارب القديم الذي يطلق سهامـه نحو

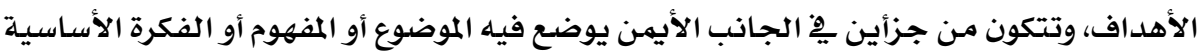

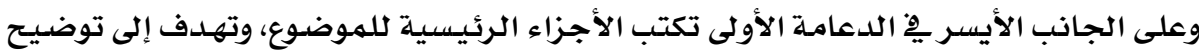

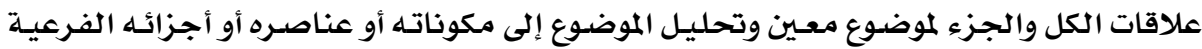

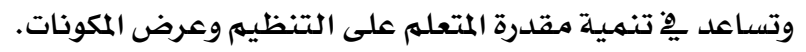

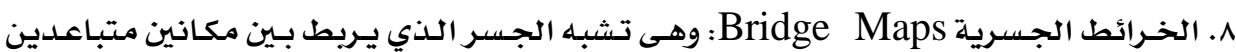

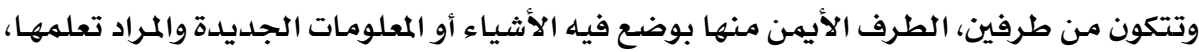

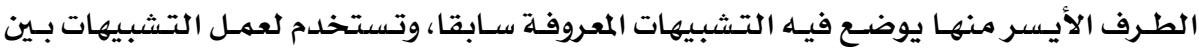

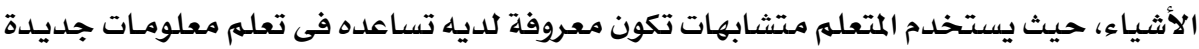

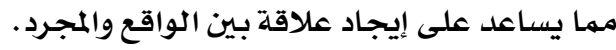

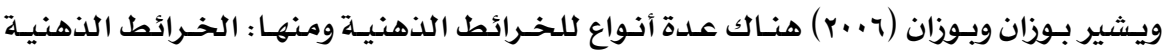

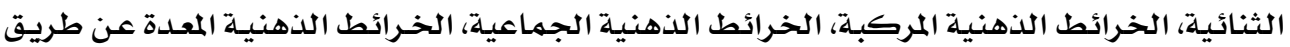

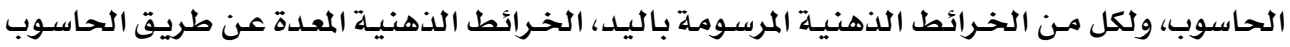

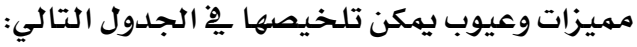

جدول (r) مميزات وعيوب الخرائط الذهنية المرسومـة باليد والمعدة بالحاسوب

\begin{tabular}{|c|c|c|}
\hline عيوبها & ميزاتها & نوع الخريطة \\
\hline 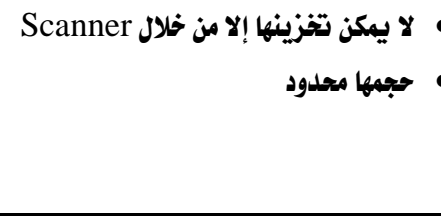 & غير مكلفة & باليلد \\
\hline 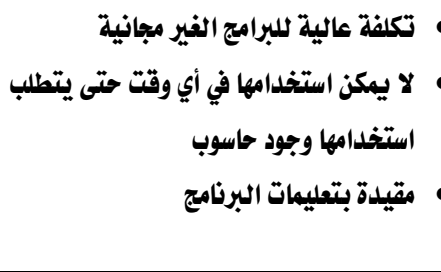 & 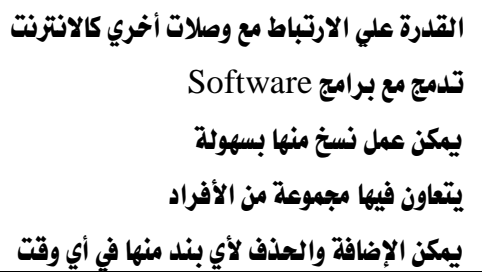 & بالماسوب المدة \\
\hline
\end{tabular}

استخدامات الخرائط الذهنية:

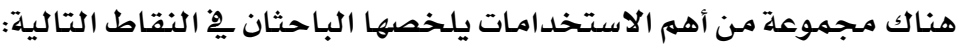
ا. للدراسـة والتـدريس والتخطيط الدراسـي، والتقويهم وتحسين الدذاكرة وتلخيص الكتب بهدف الحفظ أو القراءة أو تلخيص المحاضرات، وكتابة المقالات والبحوث. r • حل المشاكل واتخاذ القرارات والمتابعات وجلسـات العصف الذهني و للتعبير عن المشاعر والعـلاج بالخرائط الذهنية، وتنظيهم جداول الأعمال ومحاضر الاجتماعات وتتظيم الوقت. 


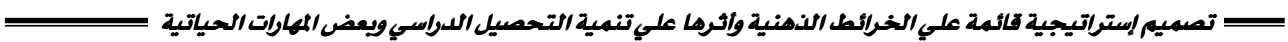

r. التخطيط والتحليل وتنظيم المعلومات وتمييز العلاقات بين النقاط الرئيسية.

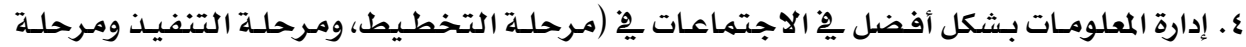

المتابعة

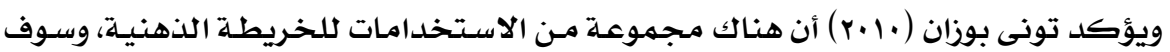

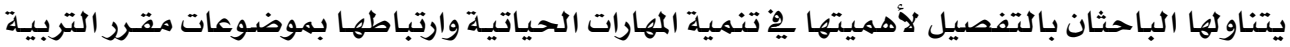

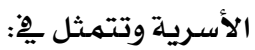

ا. التطبيقات الشخصية (معرفة الذات):

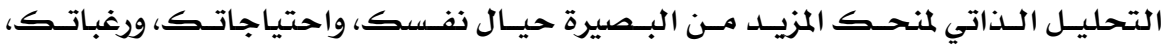

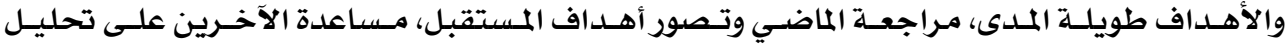

أنفسهم. والاهمه.

مزايا خرائط العقل الخاصة بتحليل الذات:

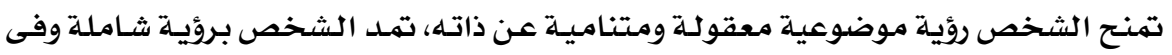

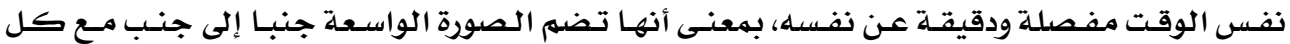

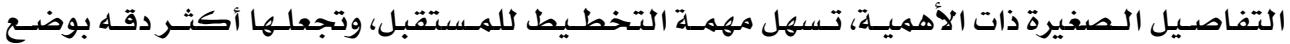

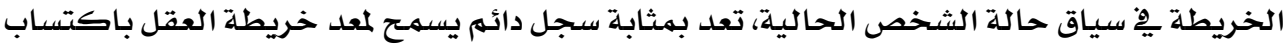

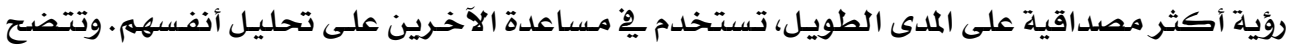

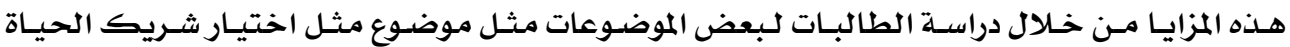
والتوافق بكل أنواعه.

\section{r. استخلام الخرائط الذهنية في حل الشكلات واتخاذ القرار} • حل المككلات الشخصية والمشكلات التي تقع بين الأشخاص. مزايا حل المشكلات التي تقع بين الأشخاص بواسطة خرائط العقل:

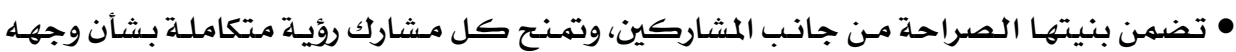

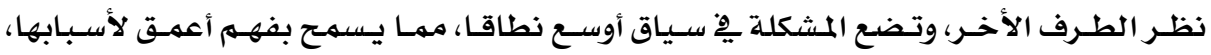

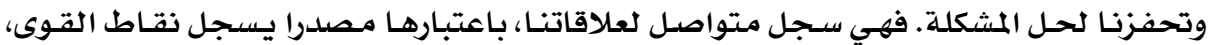

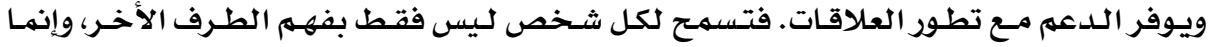

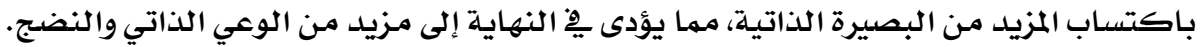

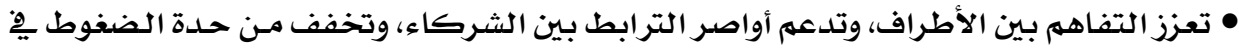

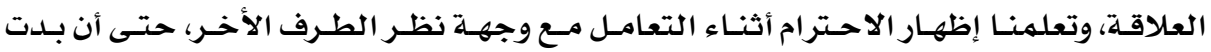

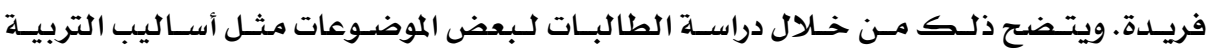

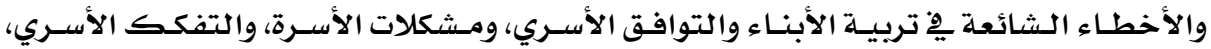

$$
\text { ومشكلات أطفال الشوارع. }
$$


r. استخلدام الخرائط الذهنية في إدارة الوقت:

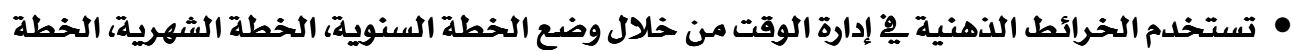
اليومية، فضلا عن آلية تخطيط الحياة الئهية اليومية. مزايا الخرائط الذهنية يِّ إدارة الوقت:

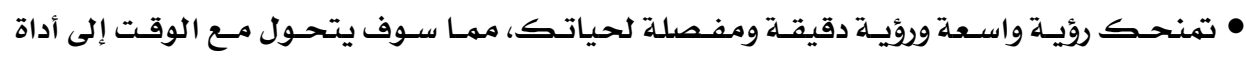

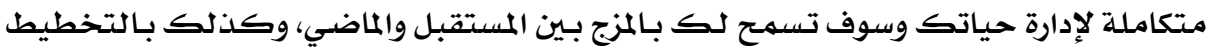

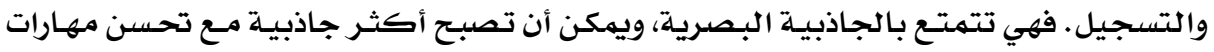

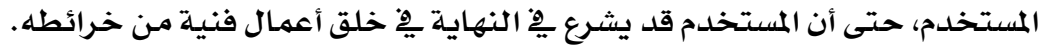

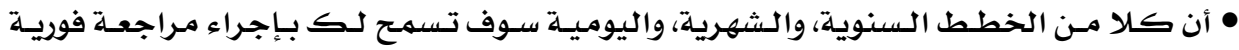

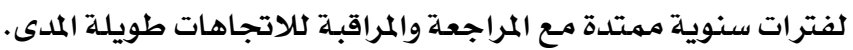

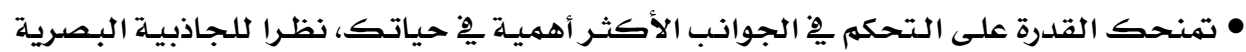

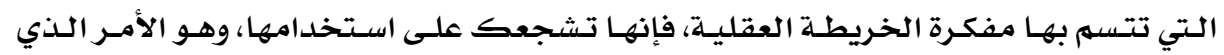

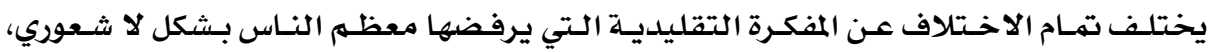

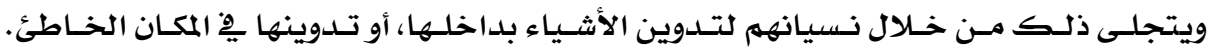

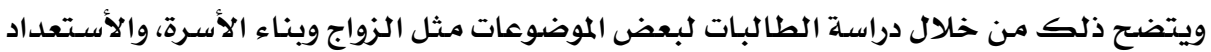

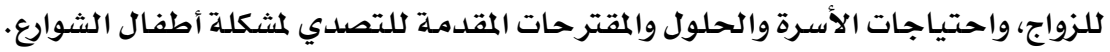
ع. استخدام الخرائط الذهنية في التطبيقات العائلية (المشاركة وتحمل المسئولية): • خريطة العقل الجماعية كلاستذكار العائلي، من خلال: يوم دراسي لإعداد خريطة العقل الخاصة بالعائلة، الجانب التطبيقي لخريطة العقل الجماعية الاستخاصة العائل بالعائلة. مزايا إعداد خريطة عقلية للعائلة (المشاركة وتحمل المسئولية):

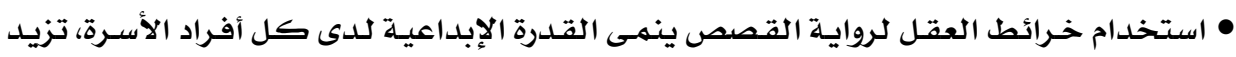

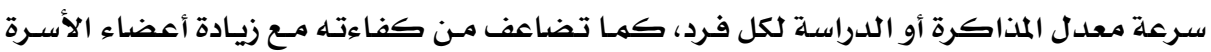

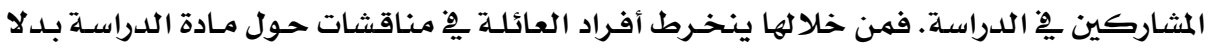

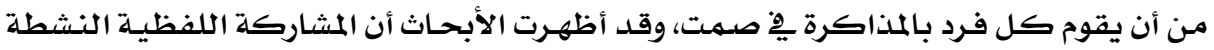

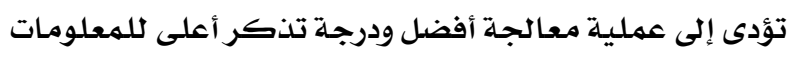

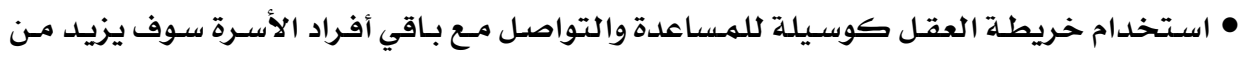

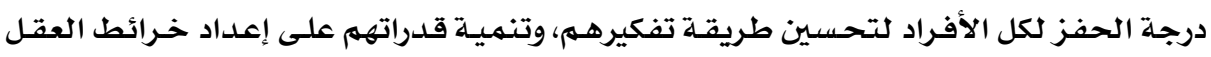

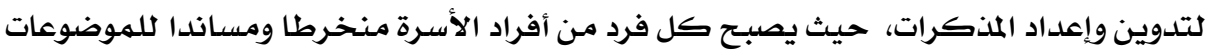

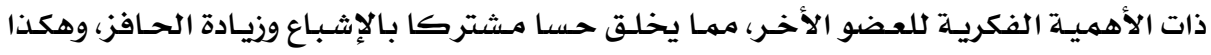

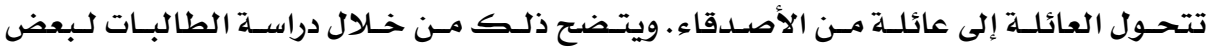

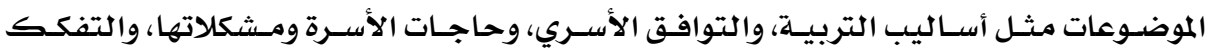
الأسري، وأطفال الشوارع. 


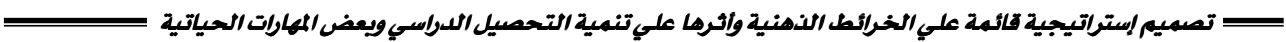
ه استخدام الخرائط الذهنية في التطبيةات التعليمية والتفكير(الاتصال والتواصل):

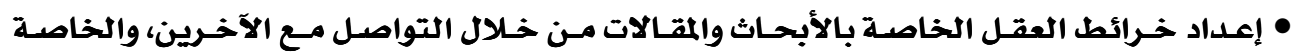

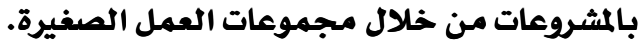
مزايا استخدام الخرائط الذهنية ـِ التطبيقات التعليمية والتفكير(الاتصال والتواصل): • تعمل بشكل فوري على بث روح التشويق لـدى الطالب، وبالتالي تجعلـه أكثر تعاونا واستعلدادا

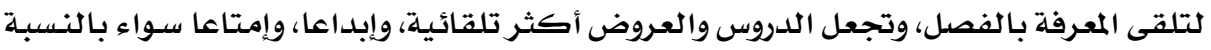

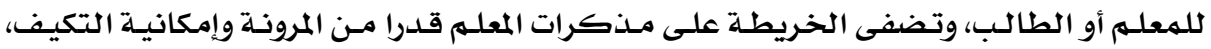

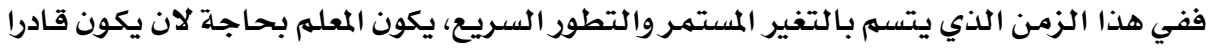

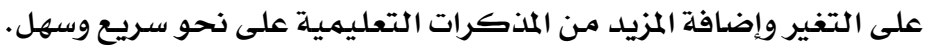

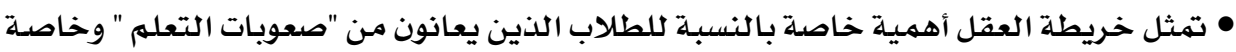

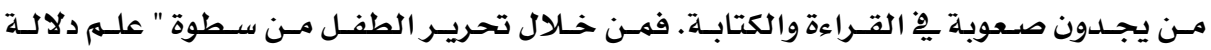

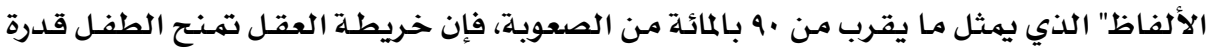

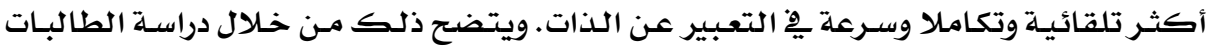

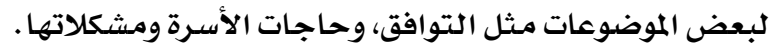

7. خريطة العقل الرائدة: • إعداد خريطـة عقل لكتـاب، إعداد خـرائط عقليـة للمـحاضـرات، وشـرائط الفيـديو، والحاسبـات،

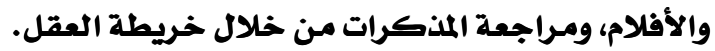
مزايا إعداد المذكرات عن طريق خرائط العقل وخريطة العقل الرائدة:

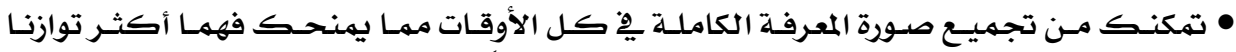

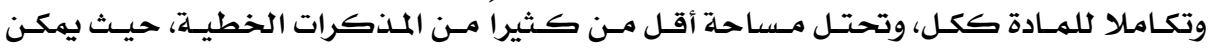

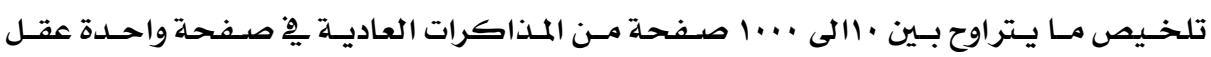
كبيرة.

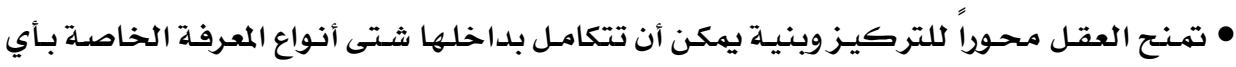

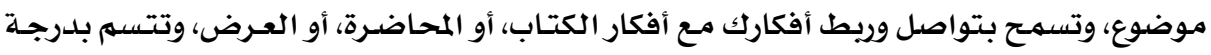

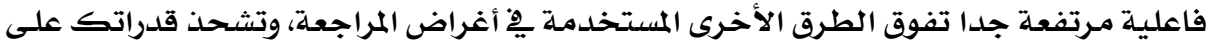

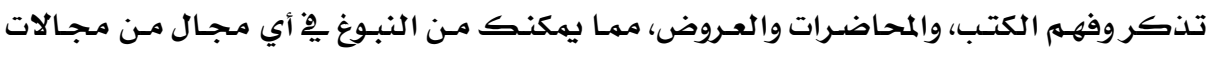

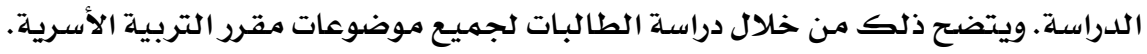

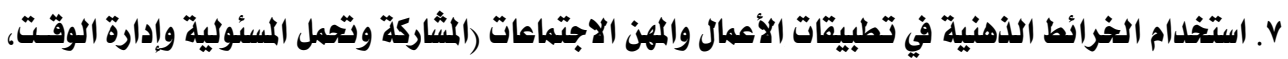
حل مشكلات واتخاذ القرار): • إعداد خرائط عقلية على المستوى الفردي، وعلى المستوى الجماعي، ورئاسة اجتماع بواسطة خريطة 
• تضمن تفهم كل شخص لوجهات نظر غيره مـن المشاركين، تضع كل المشاركات ِِّ السياق

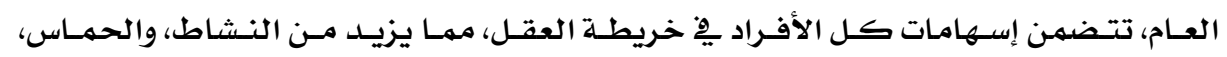

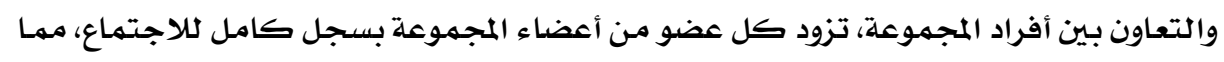

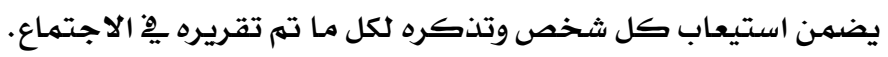

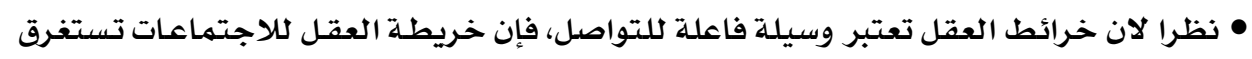

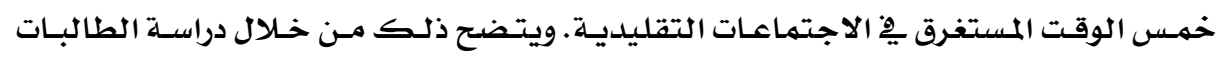
لجميع موضوعات مقرر التربية الأسريـة.

\section{تطبيقات الخرائط الذهنية في التعليم والتعلم موضوعات مقريتربية التيرية}

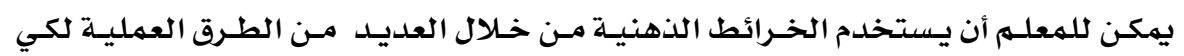

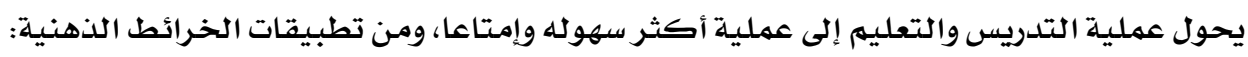
ا ـ تقديم العروض التدريسية بصورة فاعلة دون الاحتياج إلى حمل قصاصات أوراق للتذكر.

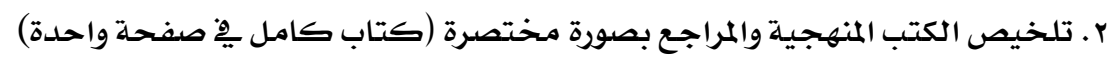

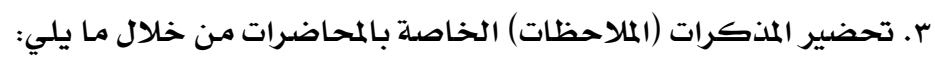

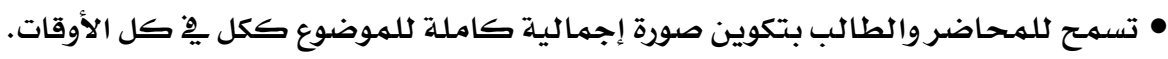

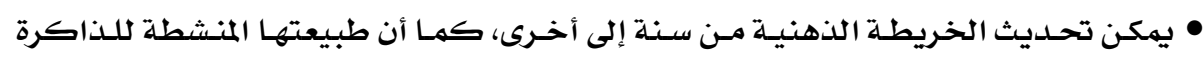

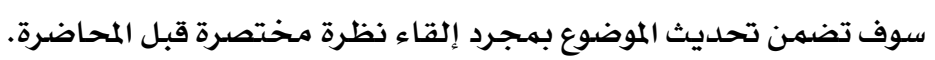

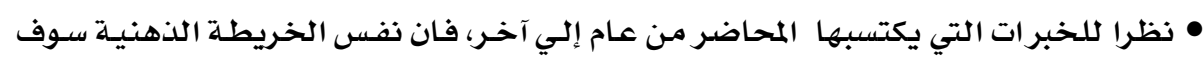

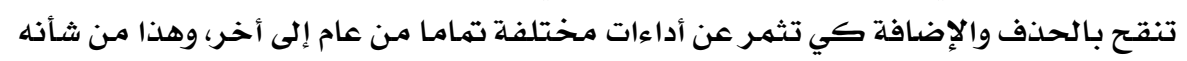

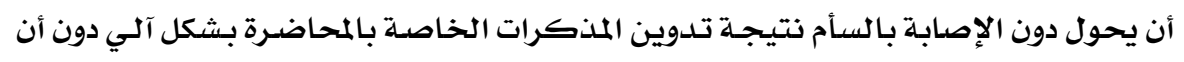

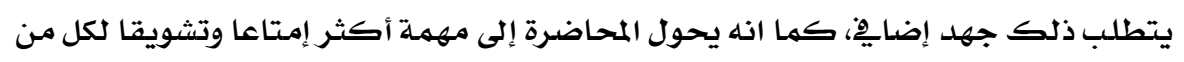

$$
\text { المحاضر والطالب والمستمـع. }
$$

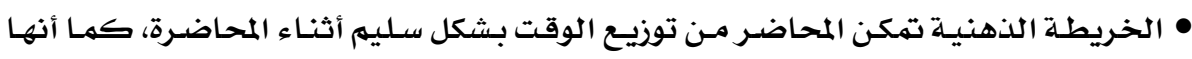

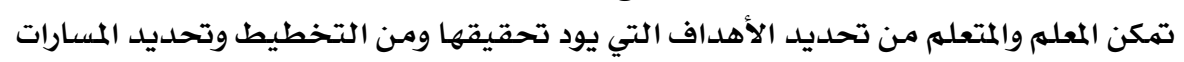

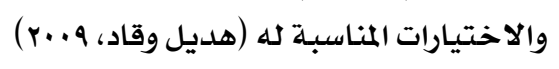

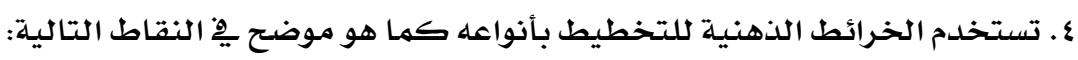

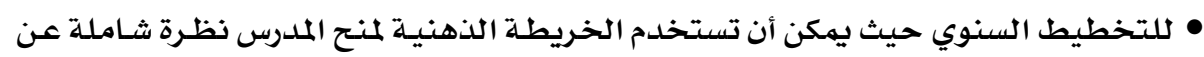

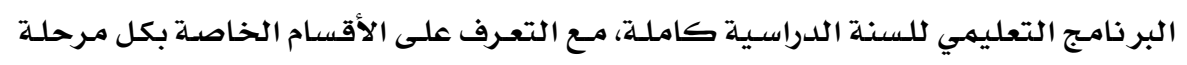

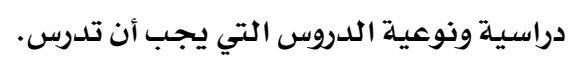

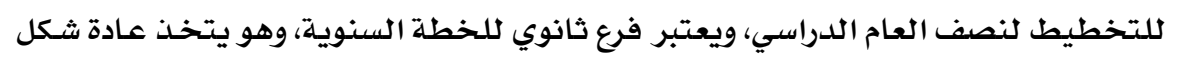

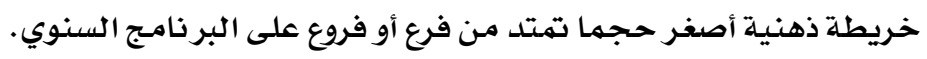


בصب تصميم إستراتيجية قائمة علي الخرائط النهنية وأثرها علي تنمية التحصيل الدراسي وبعض المهارات الحياتية لس

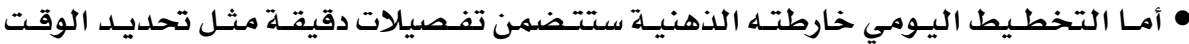

لبدايلة ونهاية اليوم الدراسي، والمواضيـع التي سيتم تغطيتها وحالة الغرفة النصفية.

• تستخدم الخريطة الذهنية لشرح أو تقديم الدروس وذلك عن طريق:

• إعداد خريطة ذهنيـة لدرس معين وتوضيح كافة التفاصيل المتعلقة بـه، وتقديهـه للطلبـة عن

طريـق استخدام جهاز العـرض الرأسـى(Over head projector) و(Power Point)،

وهذا سوف يثير انتباه الطلبـة ويدعم الفهم واستذكار المادة.

• ويهـن إتباع نهط آخر عن طريق توزيع خرائط ذهنية للطلبـة تحمل الهيكل العـام للخريطـة،

ويطلب مــهم اسـتكماله، أو توزيـع نسـخ مـصورة بـاللونين الأبيض والأسـود لكي يقـوم الطلبـة

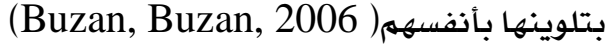

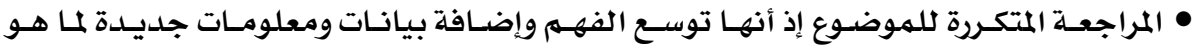

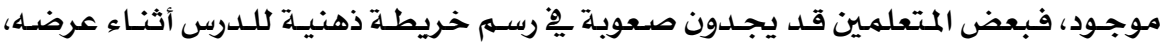

ولكن يسهل عليهم ذلك عند مـراجعتهـ. ومـراعاة الفروق الفردية عند الطلبـة إذ أن كل منههم

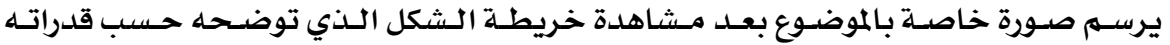

ومهاراته.

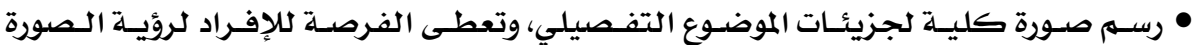

والتفاصيل كاملة وفى نفس الوقت.

• توظيـف التقنيـات الحديثـة يِّا التعلـيهم والـتعلهم كالحساسـوب، وجهـاز العـرض فـوق الـرأس،

والشـرائح، والتسسجيلات الأخـرى وغيرهـا ـ مـع اسـتخدام المعلومـات بـشكل كفء وفى الوقـت

المطلوب وتنشيط الطاقة، وإيجاد حلول إلهامية لكل مشكلة وإتاحة التعليهم مـن خـلال اللعب

والمرح.

• رسم خرائط العقل يساعد على تطوير مهارات التفكير : مهارات التفكير ِِّْ تجهيز المعلومـات،

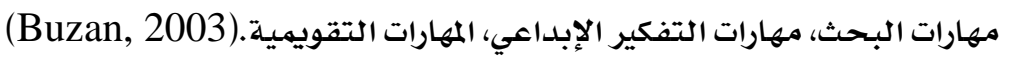

ه. يهكـن أيـضا اسـتخدام الخـرائط الذهنيـة للامتحانـات إذا كـان الهـدف مـن وراء الامتحــان هـو

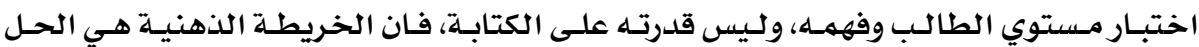

الأمثل، حيـث يهكن أن تثبـت الخريطـة للهعلـم مـا إذا كـان الطالب يعـي المادة بشكل عام أم لا،

كما أنها تلقى الضوء فورا على نقاط قوته وضعفه .كهـا أنها أيضا تسـاعد ِِ إعداد الاختبـار

$$
\text { المدرسي، وذلك من خلال وضوح الجزيئات التفصيلية للهوضوعات. }
$$

7. تعتبر الخريطة الذهنية إحدى الوسـائل المثالية يِّ التخطيط والمراقبة وتقديه المشروعات، فهي

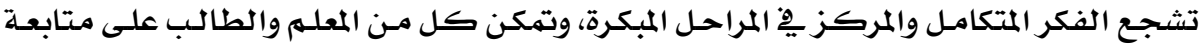

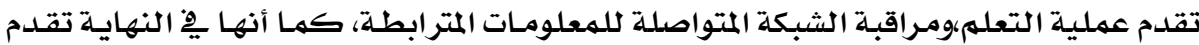
إطارا مثثاليا سواء للعروض المكتوبـة أو الشفهية (بوزان، بوزان،ج ·. . ). 
إجراءات بناء الخريطة في التدريس

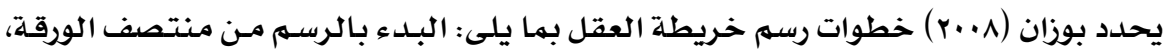

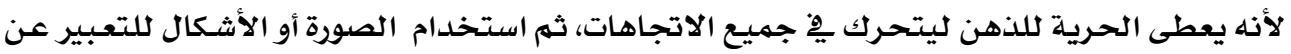

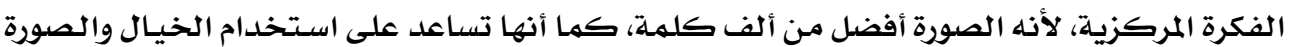

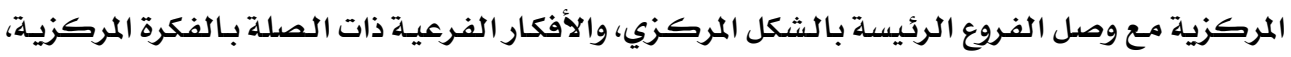

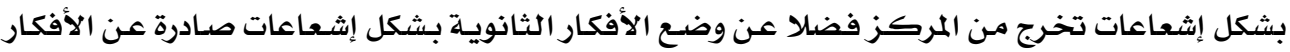

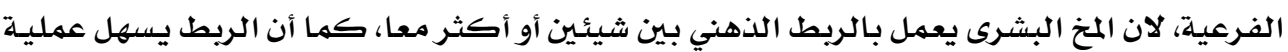

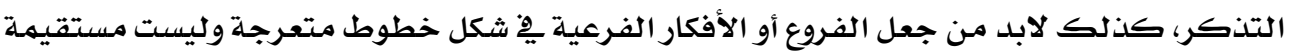

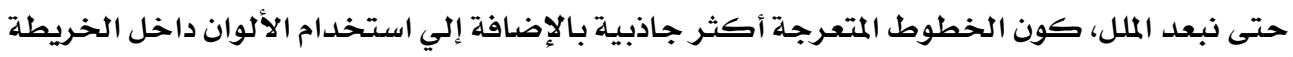

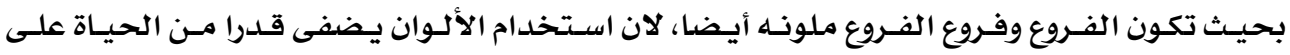

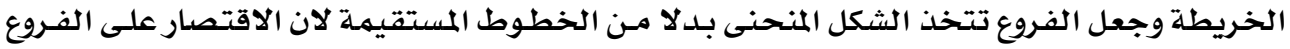

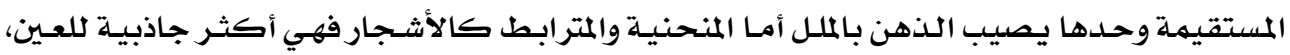
وأكثر إثارة للانتباه.

ويشير سـاندرزوكاجس (Sanders, \& Kajs, 2002)، ذوقات عبداه عبيدات و سهيلة أبو

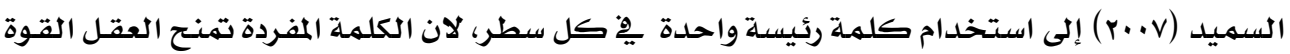

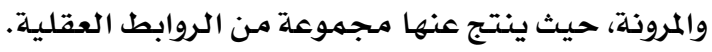

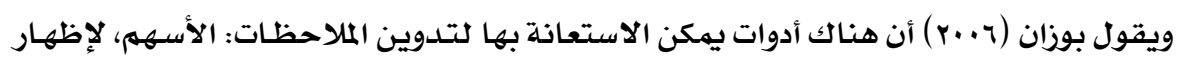

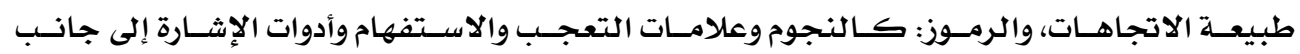

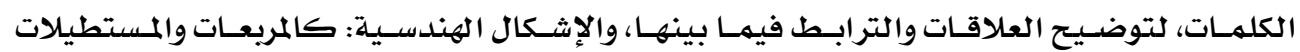

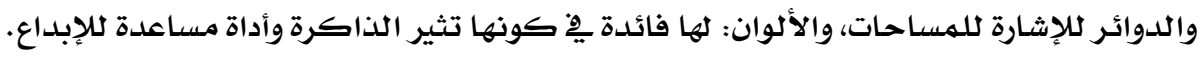
ثانياً: التحصيل الدراسي: مفهوم التحصيل الدراسي تعددت تعريفات التحصيل الدراسي فقد تعرضت لـه الكثير مـن الدراسـات والبحسوث السـابقة

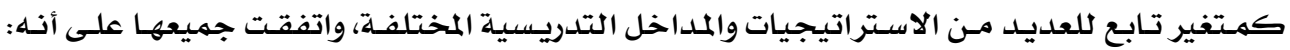

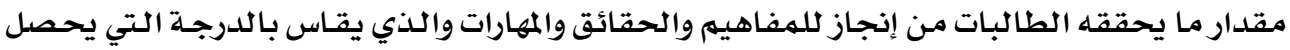

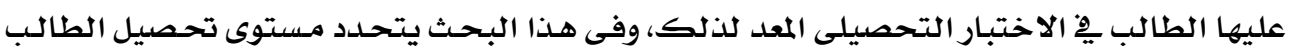

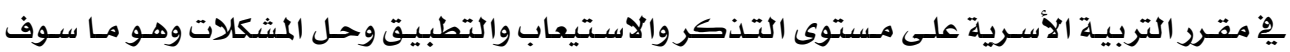

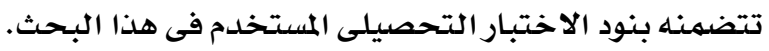
أسباب تدني الطالبات ـِ تحصيلهم دراسيا فِ مقرد التربية الأسرية

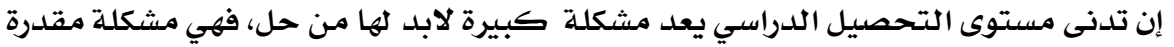

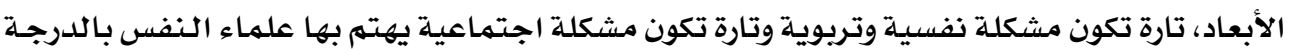


الأولى ومن ثم المربـون والأخصائيون الاجتماعيون والآباء، وقد حظيت باهتمـام الكثير مـن التربويين

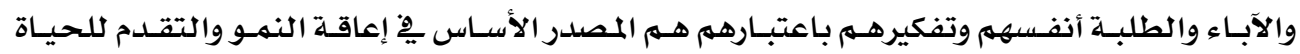

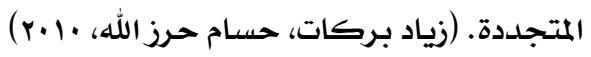

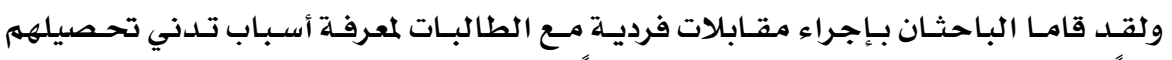

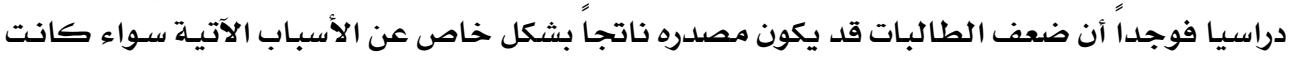
هذه الأسباب منفردة أم مجتمعدة.

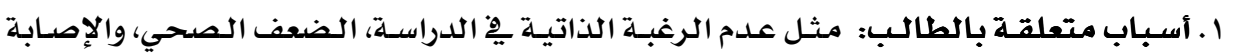

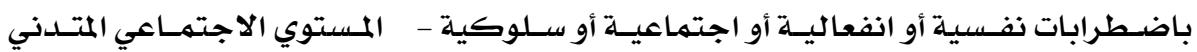

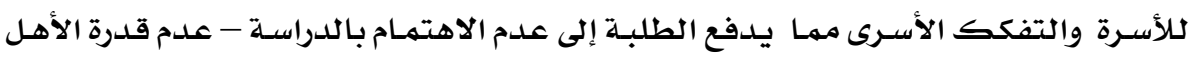

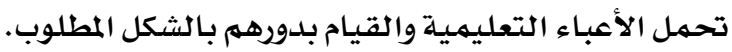

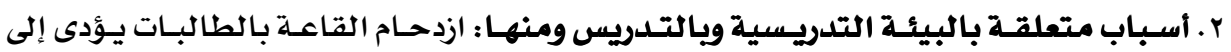

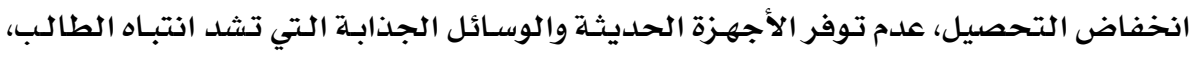

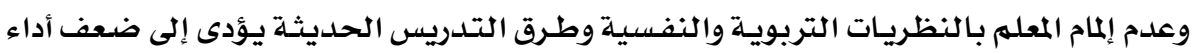

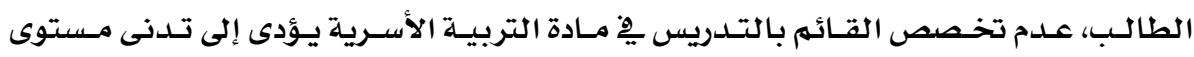
التحصيل.

\section{العلاقة بين التحصيل الدراسي والتدريس بالخرائط الذهنية}

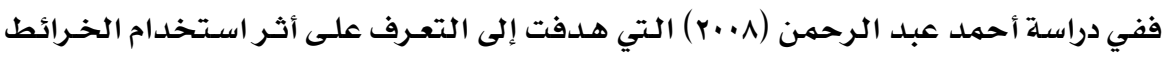

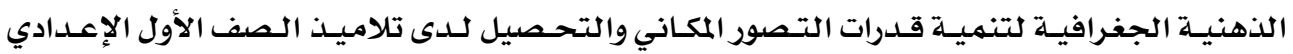

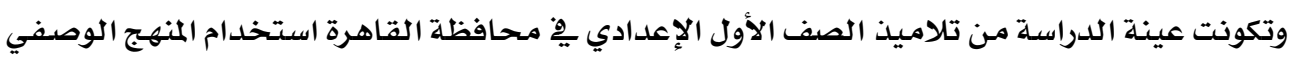

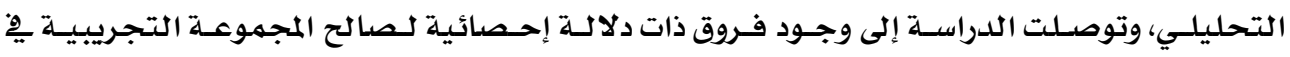

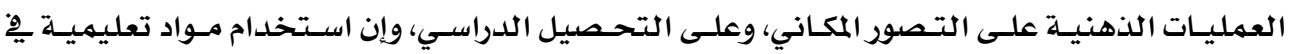

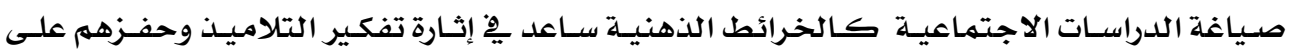

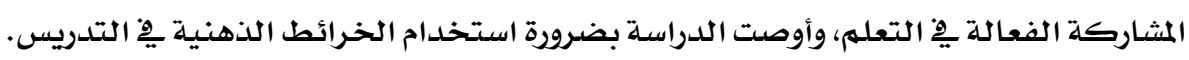
هدف نانج وآخرون (Nong, etel, 2009) مسن دراستهم التحقق مـن نتائج استخدام ثلاثلاث

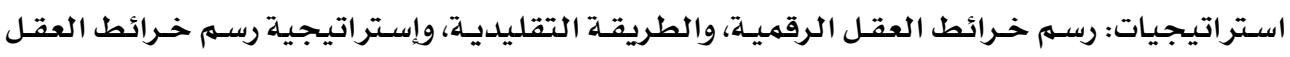

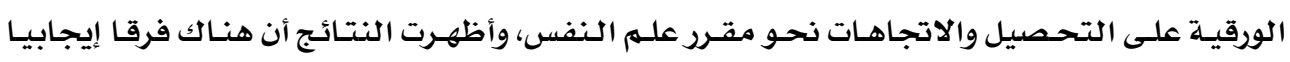

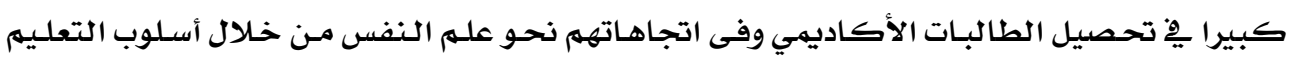
والتعلهم المستندة إلى رسهم خرائط العقل الرقيمي.

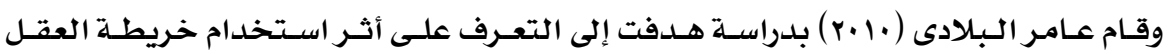

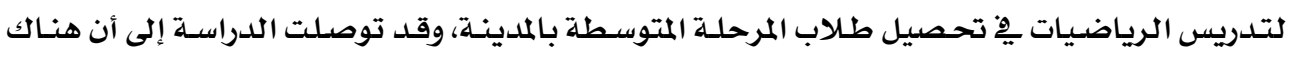

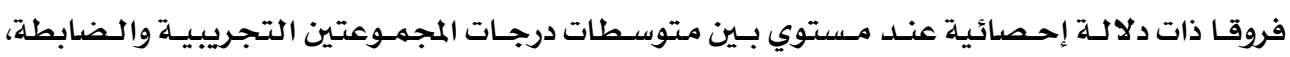

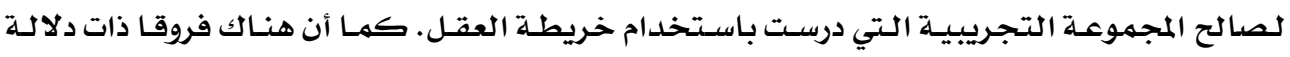




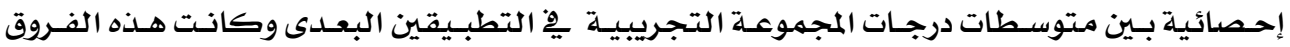
لصالح التطبيق البعدى.

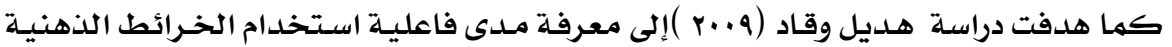

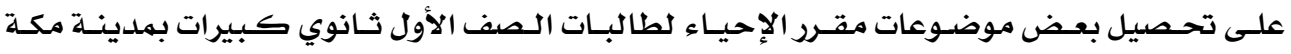

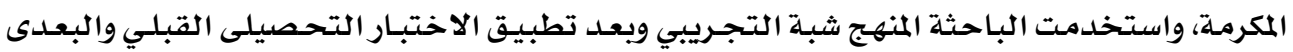

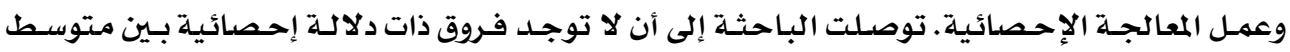

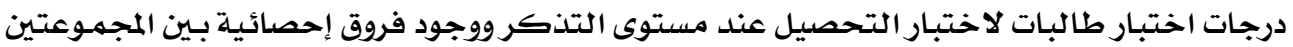
عند مستوى الفهم والتركيب والتحليل.

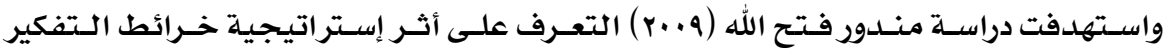

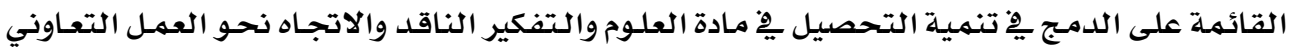

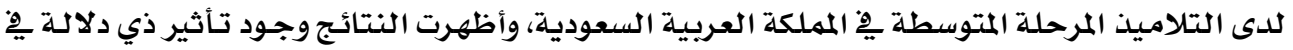

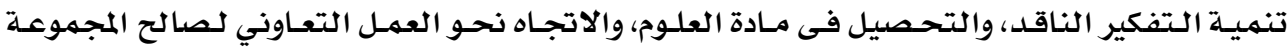

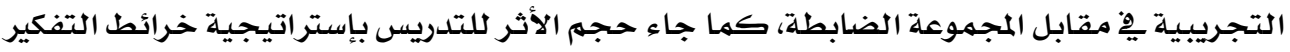

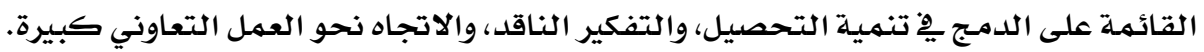

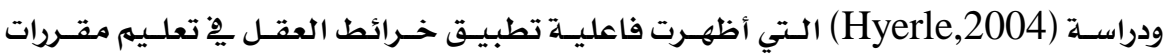

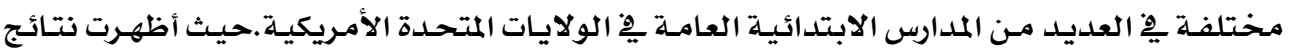

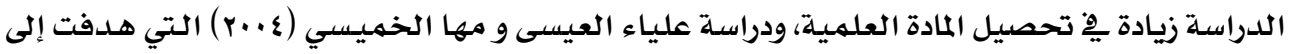

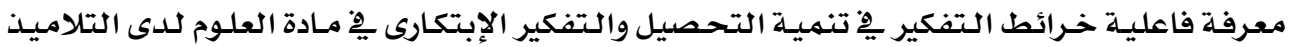

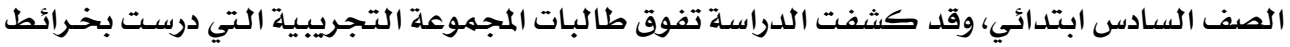

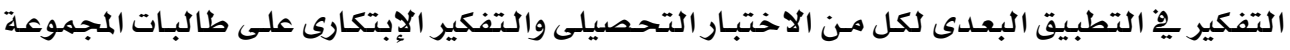

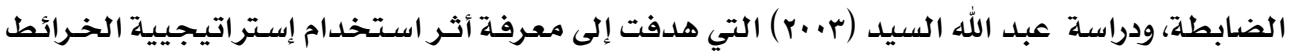

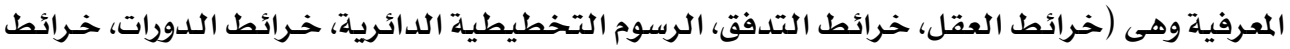

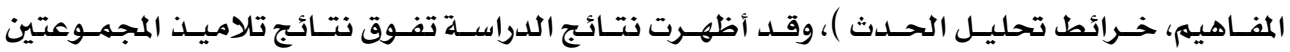

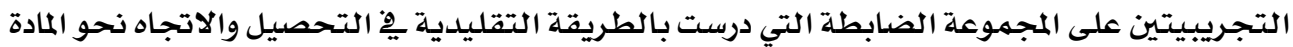

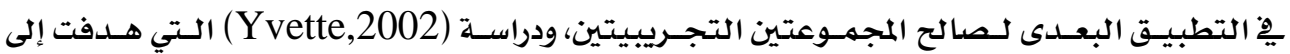

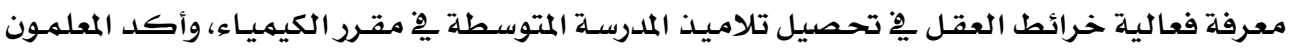

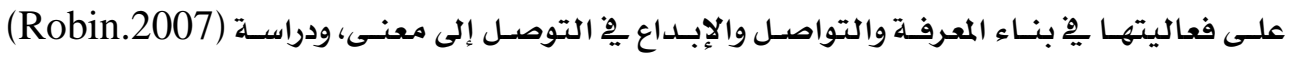

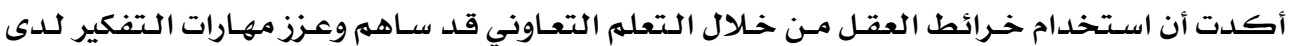

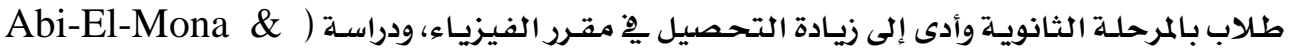

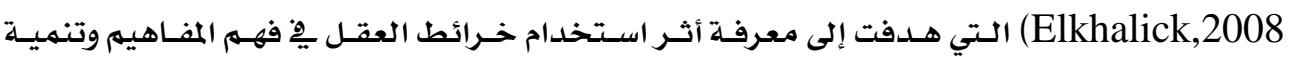

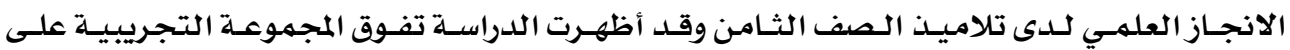

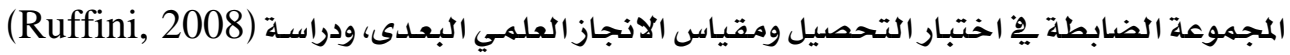


والتي أكست على فعاليـة المخططـات الرسـومية مثل الخـرائط الذهنيـة فى تسهيل عمليـة التعلهم ذا

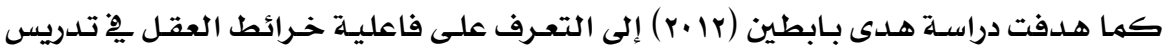

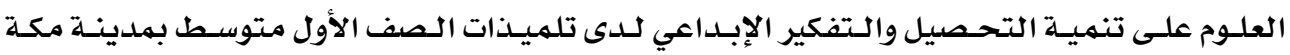

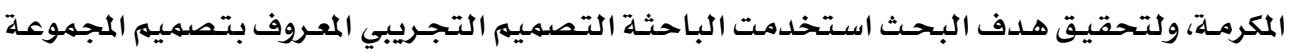

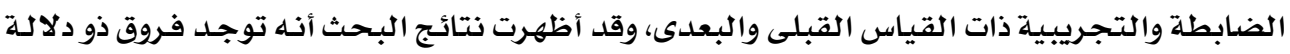

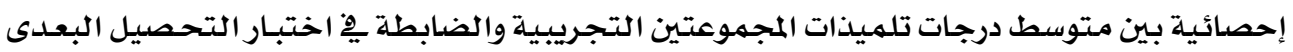

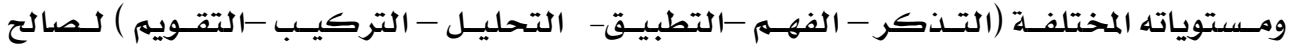

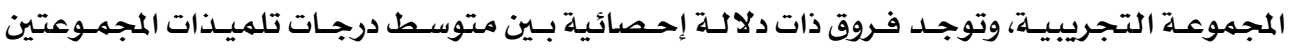

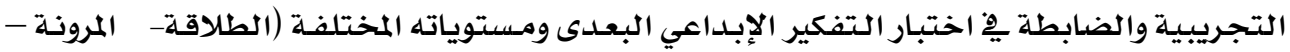

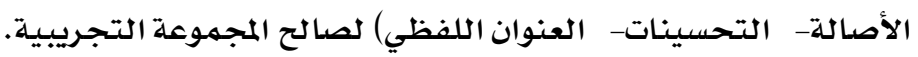

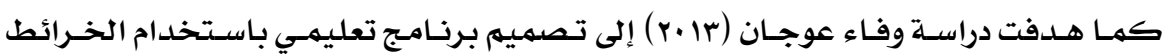

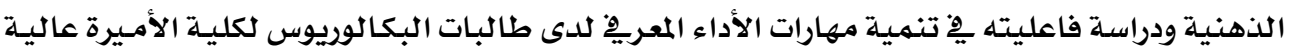

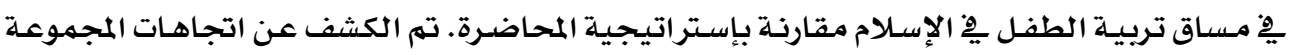

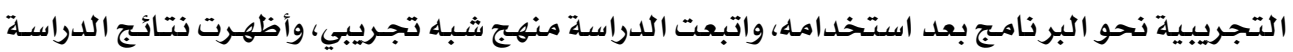

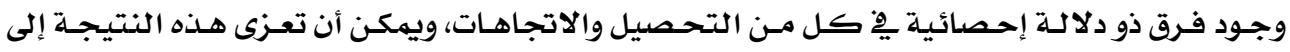
فاعلية استخدام الخرائط الذهنية. ثاثثا: المهارات الحياتية:

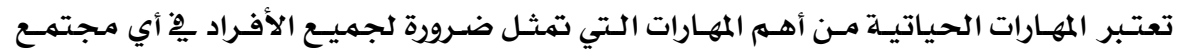

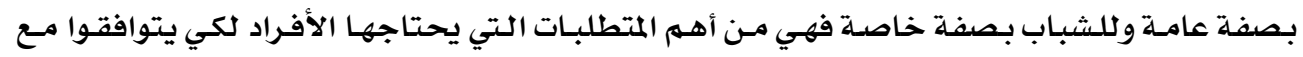

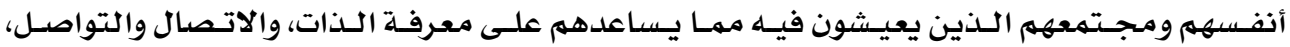

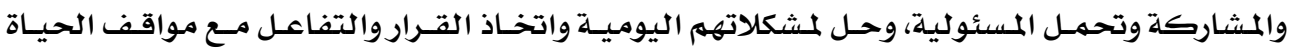
المختلفة وإدارة أوقاتهم بفاعلية.

\section{ماهية المهارات الحياتية:}

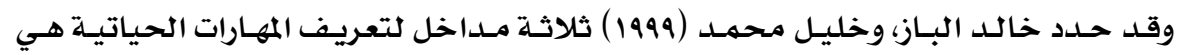

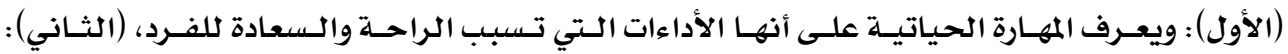

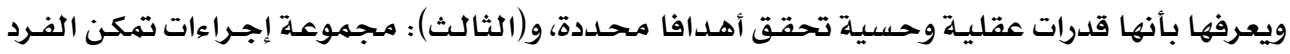

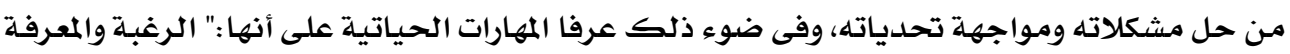

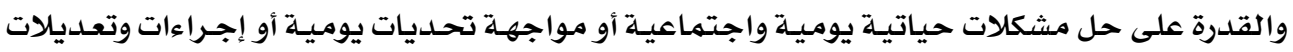

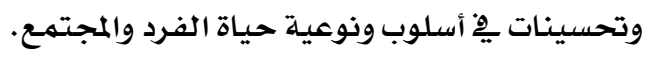

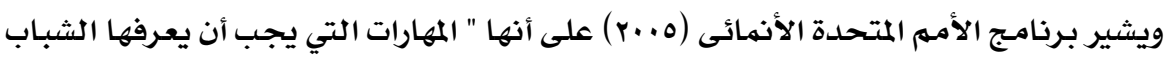

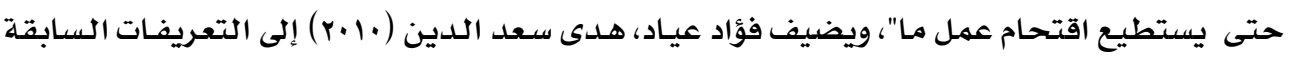




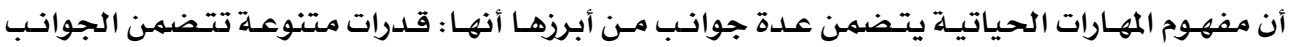

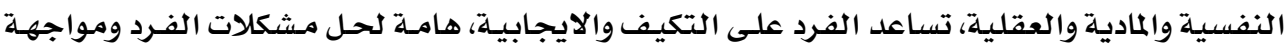

\section{أهمية المهارات الحياتية}

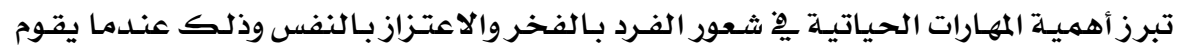

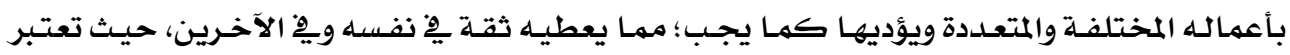

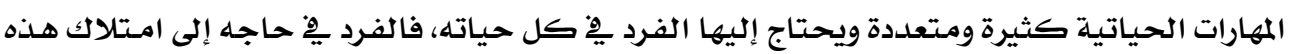

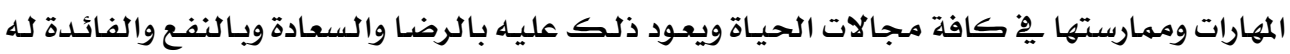

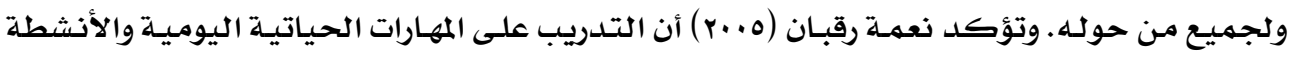

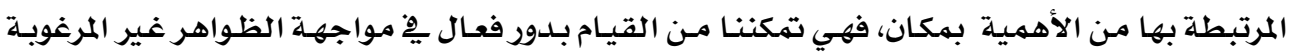

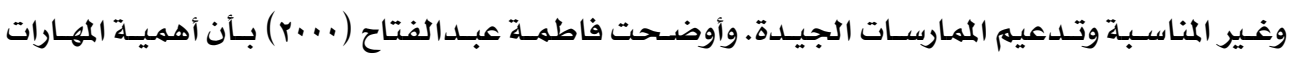

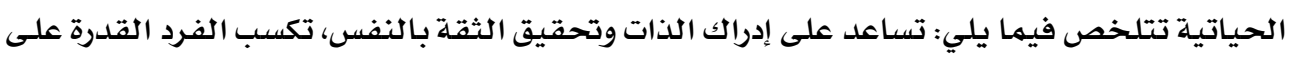

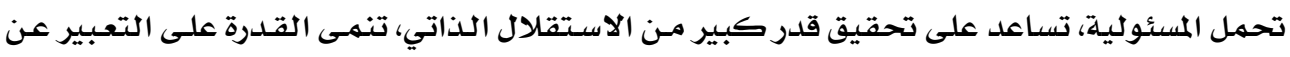

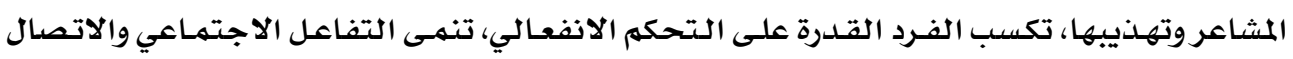

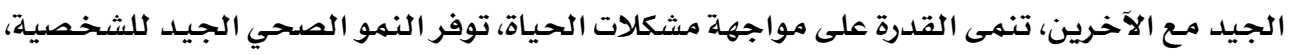

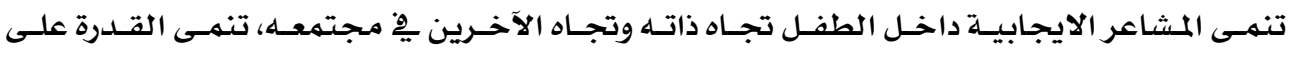

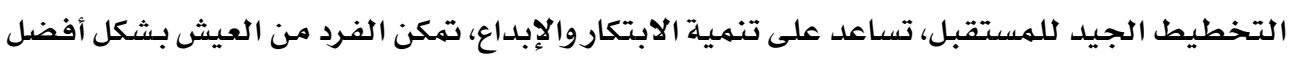

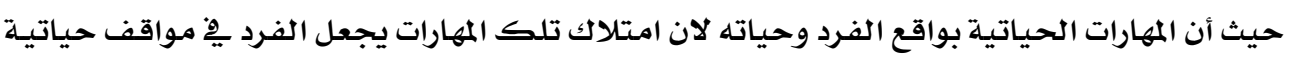

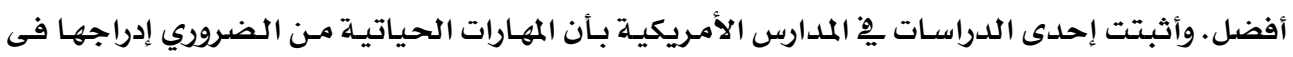

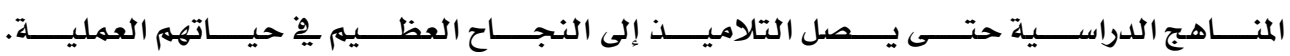

(Gamble.Baxter,69,2006)

\section{المهارات الحياتية والنظرية البنائية:}

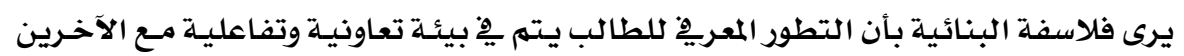

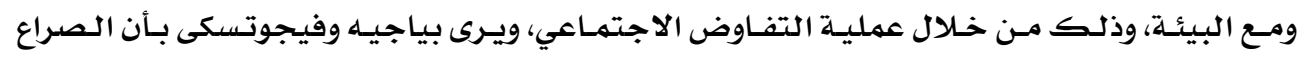

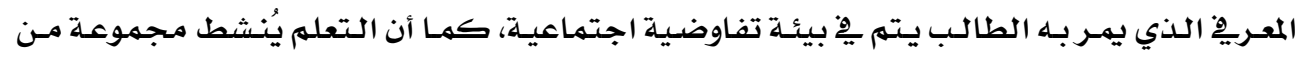

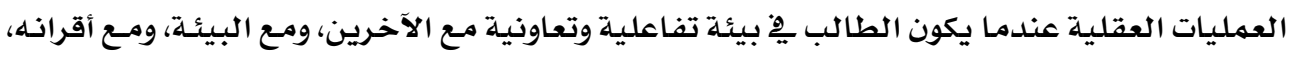

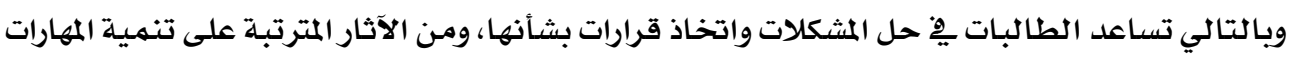
الحياتية من منظور النظرية البنائية ما يلي:

ا ـ تعلد مجموعات التعلهم التعاونية أساس لتعلم المهارات الحياتية.

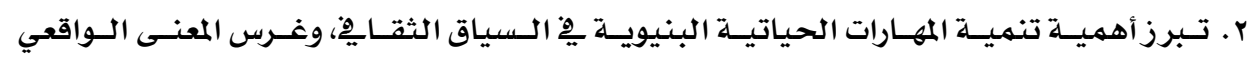

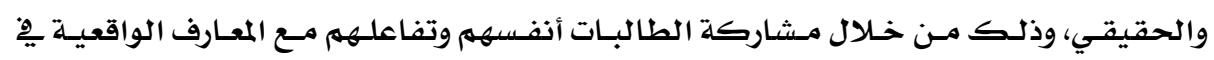
البيئة الثقافية الخاصة ودلكة بهن 
r. يتم تنمية وتطوير المهارات الحياتية من خلال تفاعل الطالبات مـ البيئة الاجتماعيـة المحيطـة

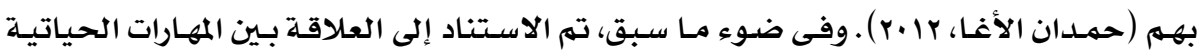

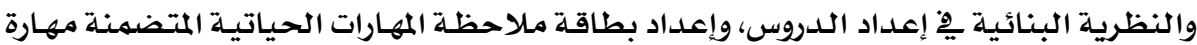

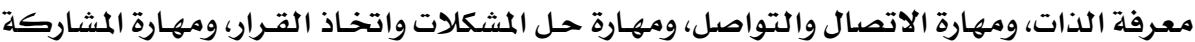

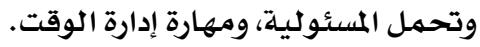

\section{خصائص المهارات الحياتية:}

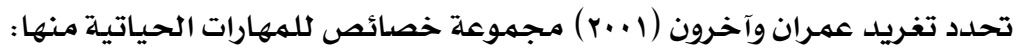
ا ـ تختلف من مجتهمع لأخر وفقا لطبيعة كل مجتهـع ومتطلباته وعاداته وتقاليده ودرجـة تقدمـهـ

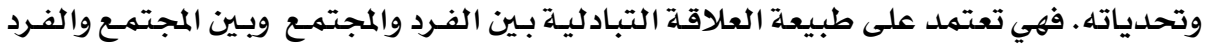
ودرجة تأثير كل منهما على الأخر.

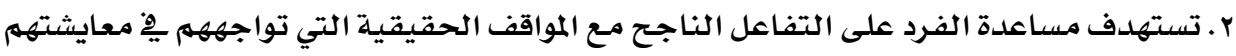

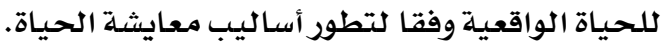

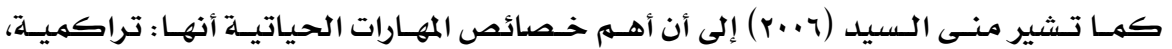

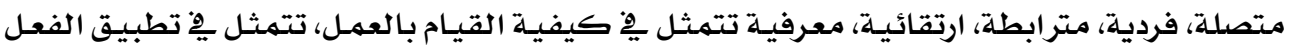

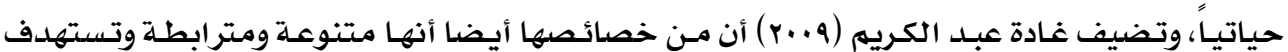

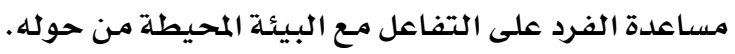
تصنيف المهارات الحياتية:

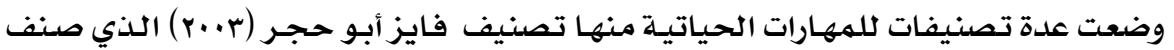

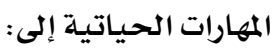

ا ـ مهارة الوعي الذاتي: هي المهارات التي تتضمن معرفة الذات، خصائصها، مصادر قوتها وضعفها،

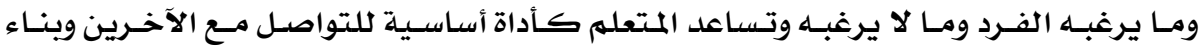
العلاقات والتعاطف معهم.

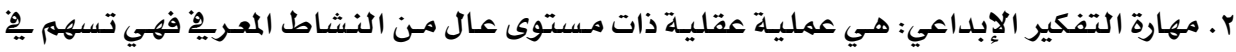

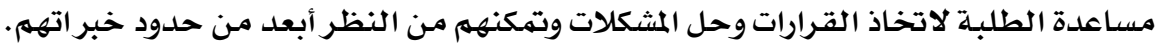

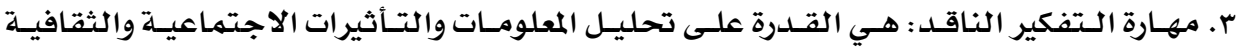
والخبر ات بطريقة موضوعية.

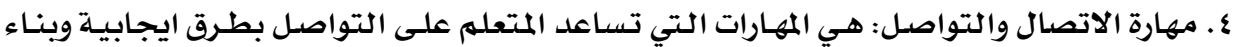

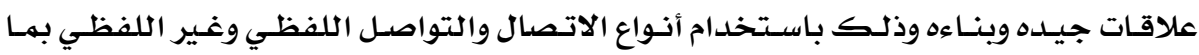

$$
\text { يتلاءم مع ظروفه وثثقافته. }
$$

ه. مهارة حل المشكلات واتخـاذ القـرار: هي تلـك المهارات التي تسـاعد المتعلهم على التعامـل بطرق

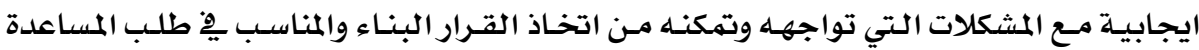
وتحديد الحلول والتسويات لتلك المشكلات. 


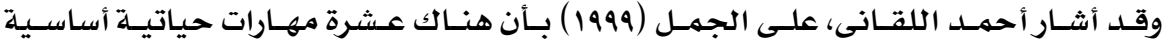

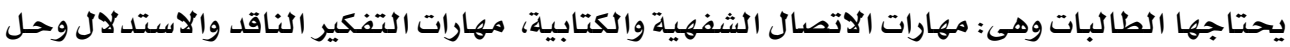

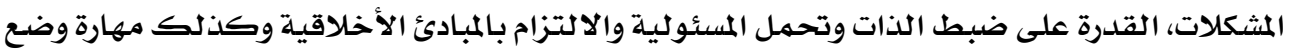

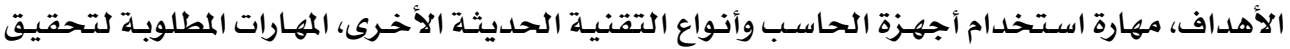

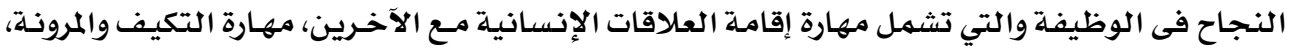

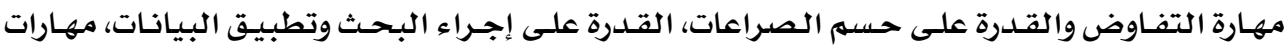
القراءة الناقدة والفهمه.

وقد صنفتها شيماء إبراهيم (ج +.r) إلى: مهارات الحفـاظ على الحيـاة: وتصنف إلى مهارات

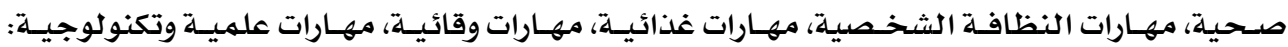

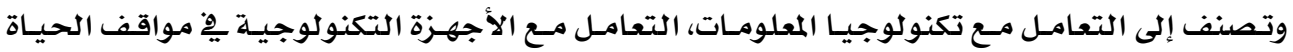

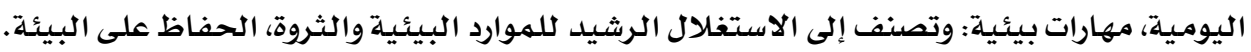

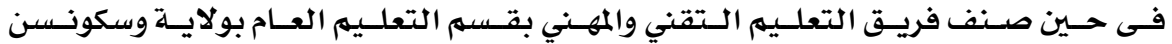

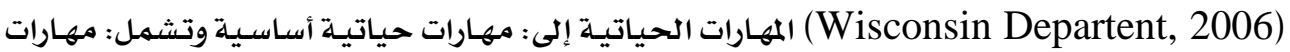

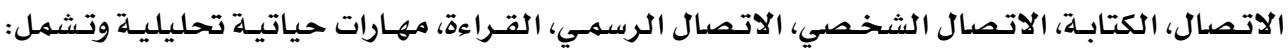

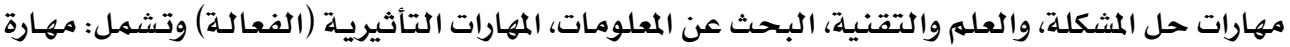

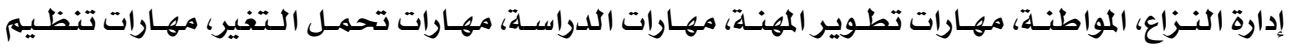

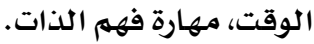

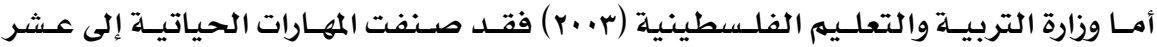

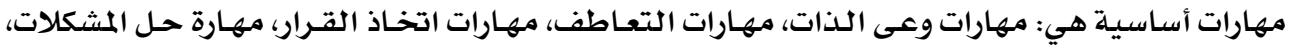

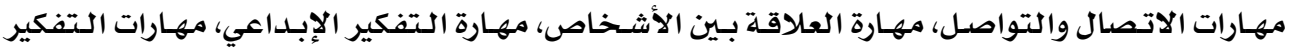

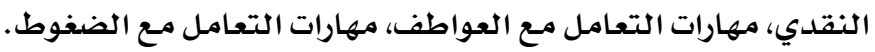
أهداف المهارات الحياتية هِِ العملية التدريسية:

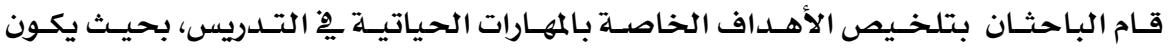
الطالبات قادرين على ما يلي:

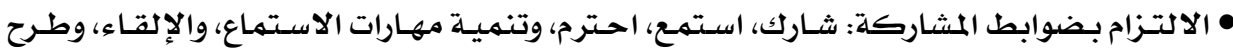

$$
\text { التساؤلات، وكتابة التقارير. }
$$

• غرس قيهم التعاون والتسـامح والصدابه والكرم والضيافة، والتعامل مـع الأقران بشكل ايجابي.

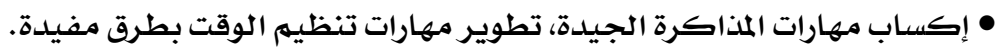

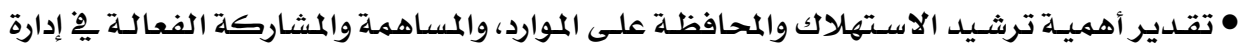

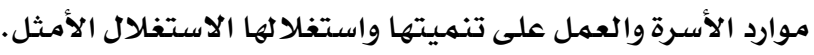




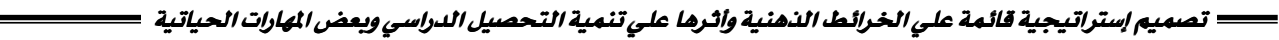
• تنمية مهارة اتخاذ القرارومهارة حل المثكلات وذلك من خلال: ريط الأسباب بالنتائج، التفكير

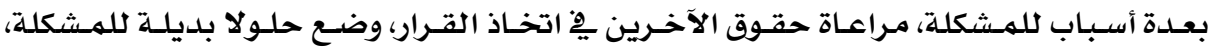
تطبيق أفضل الحلول لمواجهة المشكلة.

• تطوير مهارات حسن التصرف ِِّ المواقف الطارئة، والثقة بالنفس عند مواجهة مواقف الحئة الحياة. • تقدير قيمة النظافة والاعتناء بنظافة الجسم والمظهر الشخصي واختيار الملابس.

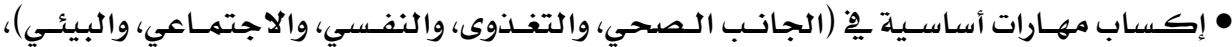

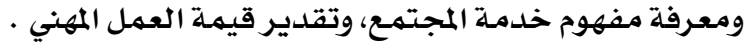

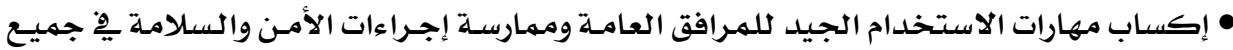
التعاملات • ممارسة مهارات التفكير الناقد ِِّ مواقف حياتية مختلفة ومتعلددة.

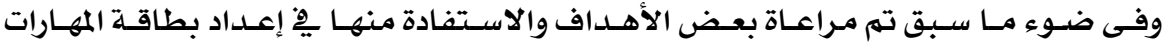
الحياتية وخصوصا مهارة الاتصال والتواصل، ومهارة معرفة الذات، ومهارة حل المشكلات واتخاذ القرار،

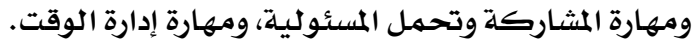
المهارات الحياتية وعلاقتها بأهداف مقرد التربية الأسرية: يعد مقرر التربية الأسرية مـن المقررات الضرورية يف جميـع مـراحل التعليهم وخاصـة التعليهم الجامعي، ويتضح ذلك من خلال أبرز الأهداف المرتبطة بالمهارات الحياتية:

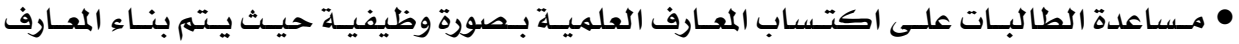

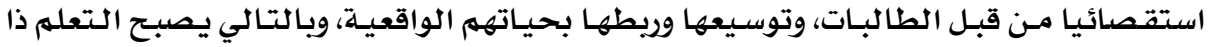

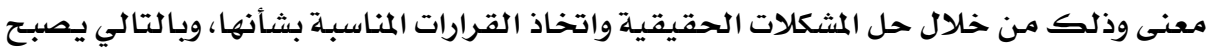

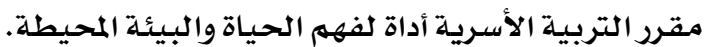

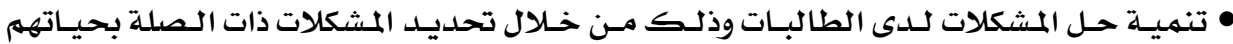

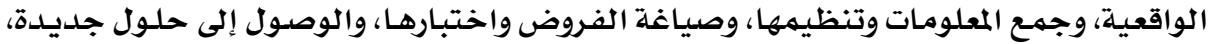
و تطوير قدرات الطالبات على الاستقصاء العلهي، وحل المشكلات، وحل القرار.

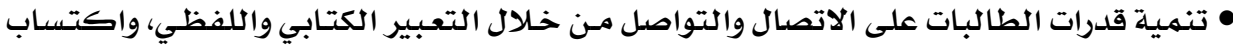
الطالبات لمهارات عملية (أدائية). وبالنظر إلى الواقع الحالي ِِِ كتاب التربية الأسريـة للفرقة الأولى، كليـة التربيـة النوعيـة

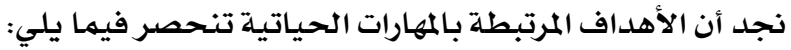
• توظيف المعارف العلميـة يِّهـم البيئسة والظـروف المحيطة بههم، إكساب مهارات عمليـة أدائيـة،

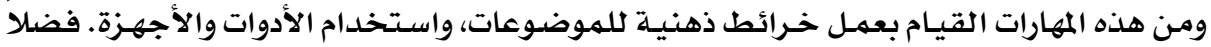

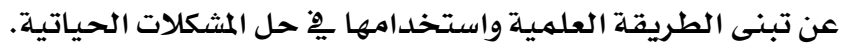


إعداد وتصميه أدوات البحث:

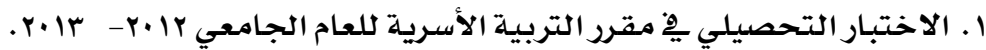

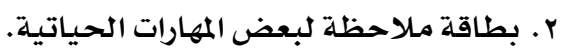

أولاً: إعداد الاختبار التحصيلى:

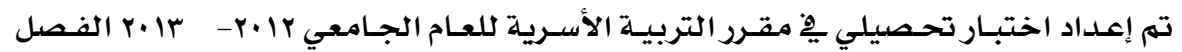

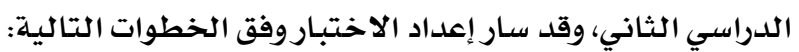

ا ـ تحديد الهدف من الاختبار:

يهـدف الاختبـار إلى قيـاس التحصيل عند مستويات: التذكر والفهـم والتطبيق والتحليل

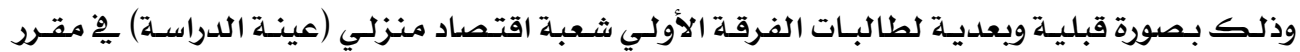
التربية الأسرية.

r r تحليل محتوى مقرد التربية الأسرية:

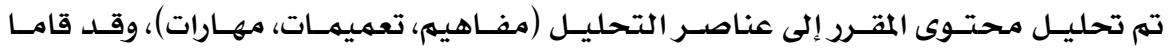

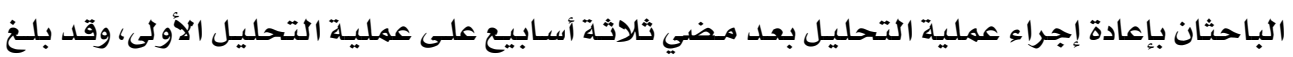

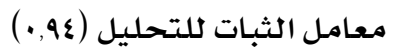

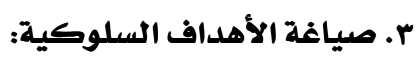
تم صياغة الأهـداف السلوكية لدروس موضـوعات المقرر وفق المستويات (المعارف والمفـاهيم،

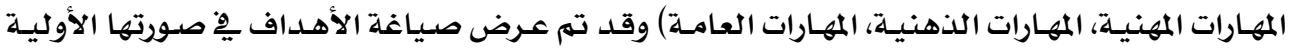

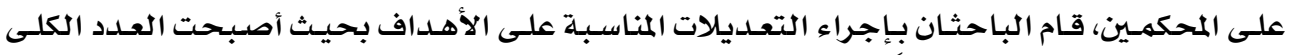

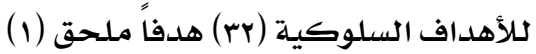
ع. تحديد الأهمية النسبية والوزن النسبي لمكونات الاختبار:

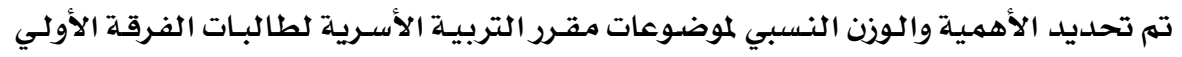

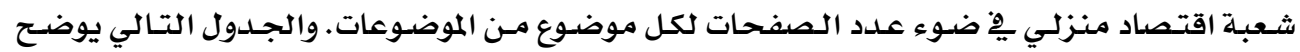

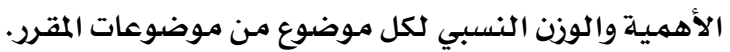

جدول (r) جدول الأهمية والأوزان النسبية للاختبار التحصيلى فِّ موضوعات مقرر التربية الأسرية مونسية

\begin{tabular}{|c|c|c|c|c|}
\hline عدد المفردات & الوزن النسبي & الأهمية النسبية & علد الصفحات & الموضوعات \\
\hline$r$ & 1,1 & $\%$ & 11 & التربية الأسرية \\
\hline$\Lambda$ & $v, 0$ & $\%$ & 0. & الأسرة بنائيا ووظيفياً \\
\hline$\wedge$ & $\Lambda, \xi$ & $\%$ rA & 09 & مؤسسات التنشئة الاجتماعية \\
\hline 1. & 9,7 & $\%$ & $7 \xi$ & احتياجات ومشكلات الأسرة المعاصرة \\
\hline$r$ & $r, r$ & $\%$ & iv & أطفال الشوارع \\
\hline r. & & $\%$ & 191 & المجموع \\
\hline
\end{tabular}


قام الباحثان هِّ ضوء الأوزان النسبية لموضوعات الاختبار ولمستويات الأهـداف ونوع المفـردات.

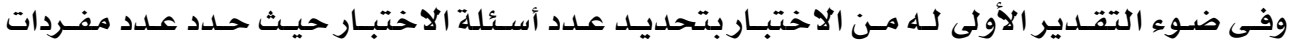

الاختبار بِّ. نسمفردة.

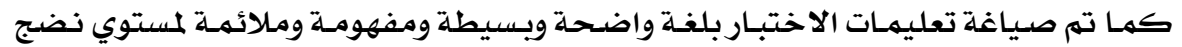

طالبات الفرقة الأولي شعبـة الإقتصاد منزلي.

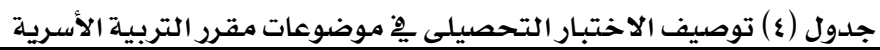

\begin{tabular}{|c|c|c|c|c|c|c|c|}
\hline \multicolumn{2}{|c|}{ المجموع } & \multirow{2}{*}{ ت ت ت تليل } & \multirow{2}{*}{ 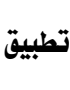 } & \multirow{2}{*}{ فهم } & \multirow{2}{*}{ تذكر } & \multicolumn{2}{|c|}{ مستوى التحصيل } \\
\hline$\%$ & العدد & & & & & & الموضوع \\
\hline$\%$ & $r$ & - & - & 1 & 1 & \multicolumn{2}{|c|}{ التربية الأسرية } \\
\hline$\% r V$ & $\wedge$ & 1 & 1 & $r$ & $r$ & \multicolumn{2}{|c|}{ الأسرة بنائيا ووظيفياً } \\
\hline$\% r V$ & $\wedge$ & 1 & 1 & $r$ & $r$ & \multicolumn{2}{|c|}{ مؤسسات التنشئة الاجتماعية } \\
\hline$\%$ & 1. & $r$ & r & $r$ & $r$ & \multicolumn{2}{|c|}{ احتياجات ومشكلات الأسرة المعاصرة } \\
\hline$\%$ & r & - & - & 1 & 1 & \multicolumn{2}{|c|}{ أطفال الشوارع } \\
\hline$\%$ & $r$. & $\xi$ & $\xi$ & 11 & 11 & العلد & \multirow{2}{*}{ المجموع } \\
\hline \multicolumn{2}{|c|}{$\%$} & $\%$ & 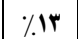 & $\%$ & $\% r v$ & $\%$ & \\
\hline
\end{tabular}

7 . عرض الاختبار فِ صورته المبدئية علي المحكمين (ضبط الاختبار):

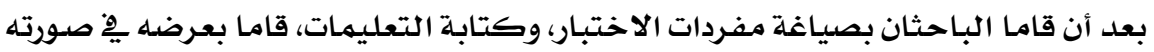

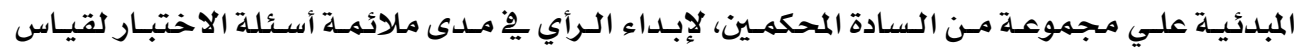

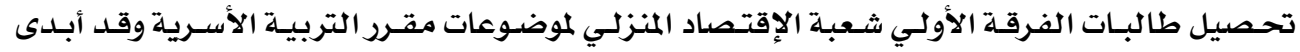

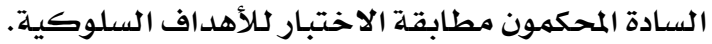

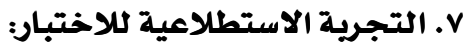

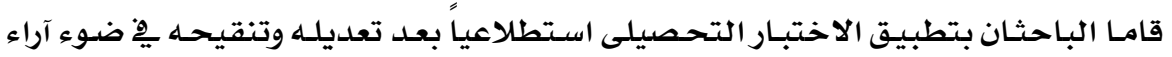

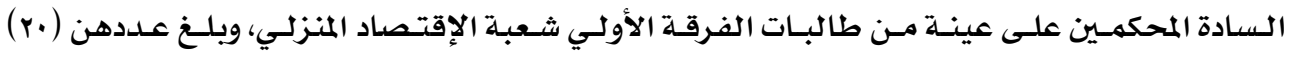

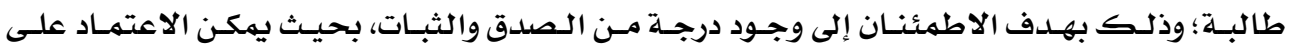

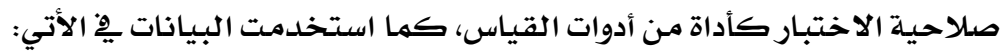

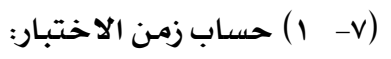

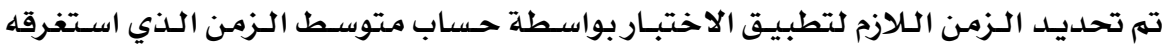

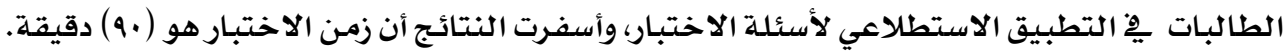




$$
\text { حساب ثبات الاختبار: (r - - v) }
$$

تم استخدام طريقة إعـادة الاختبـار لحسـاب ثبـات الاختبـار، حيـت تم تطبيق الاختبـار مـرتين

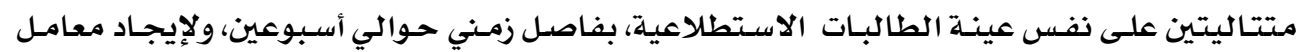

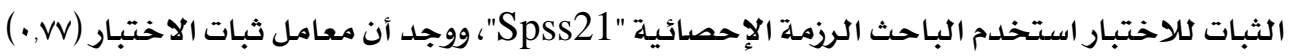

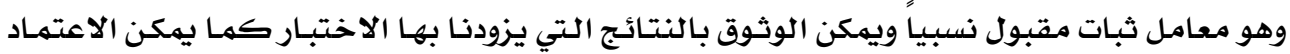
عليه كأداة بحثية. (r - - v)

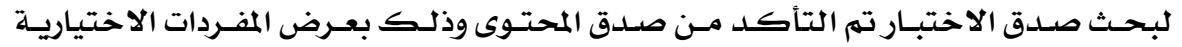

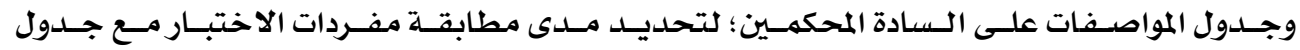

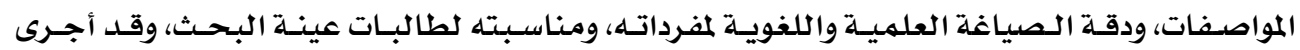

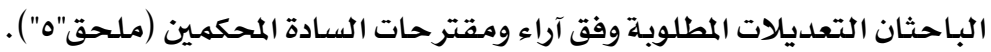
( حسـاب معاملات السهولة والصعوبية لمفردات الاختبار:

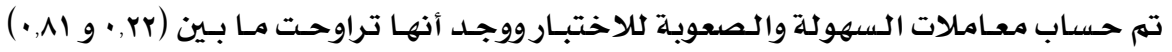

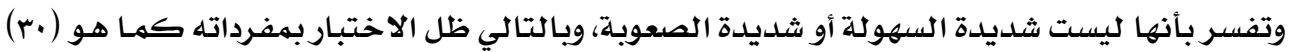
مفردة.

$$
\text { (مساب معامل التمييز لمفردات الاختبار: }
$$

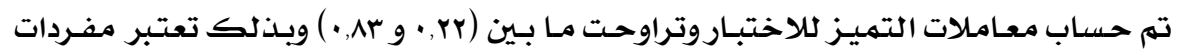
الاختبـار ذات قدرة مناسبة للتمييز. ا.ووضع الاختبار التحصيلى يِّ الصورة النهائية:

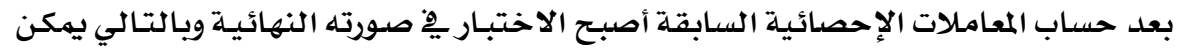

$$
\text { تطبيقه على عينة البحث (ملحق "r" ). }
$$

ثانياً: بطاقة ملاحظة المهارات الحياتية: الهدف من البطاقة:

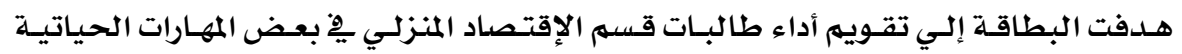

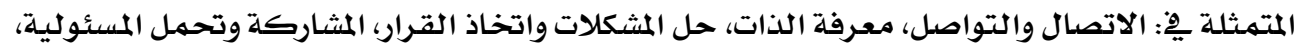

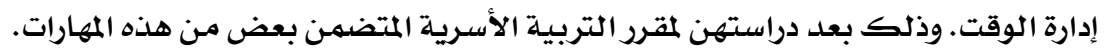
وقد مرت بناء البطاقة بالمراحل التالية:

صياغة بنود البطاقة:

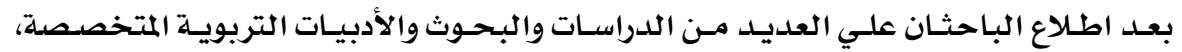

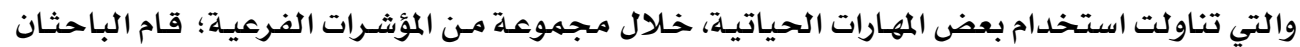




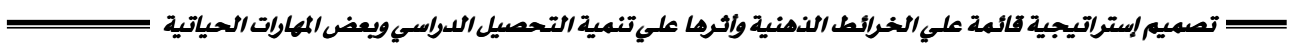
بإعـداد بنـود البطاقـة وتكونت البطاقـة مـن (ه) محساور رئيسية لكل محسور (ه) مؤثـرات تقـيس المهارة الرئيسة وهي:

أولاً: مهارة معرفة الذات. وتتضفمن المؤشرات الفرعية التالية:

$$
\begin{aligned}
& \text { 1) يعرف جيدا نقاط ضعفه وقوته. }
\end{aligned}
$$

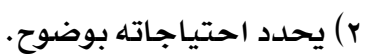

$$
\begin{aligned}
& \text { r) يستطيع التعبير عن مشاعره. } \\
& \text { ع) يستطيع التكيف مـع الظروف الطارئة. } \\
& \text { ه) لديه القدرة على ضبط النفس. }
\end{aligned}
$$

ثانياً: مهارة الاتصال والتواصل. وتتضمن المؤشرات الفرعية التالية:

I . يحسن الاستماع إلى الآخرين، ويربط بين أفكاره وأفكار الآخرين.

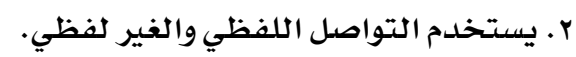

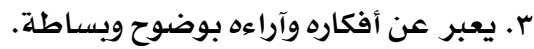

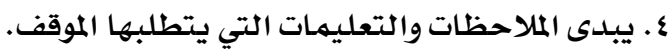

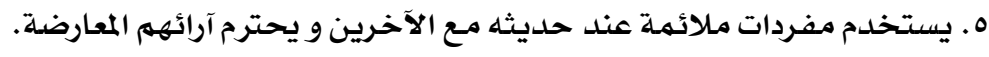

ثالثاً: مهارة المشاركة وتحمل المسئولية. وتتضمن المؤشرات الفرعية التالية:

ا ب ينجز حصته من العمل المطلوب منـه.

r r r بشارك بايجابية مـ الآخرين.

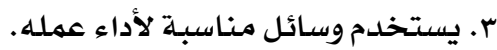

ع. يتهنى أن يكون أهلا للثقة وتحمل المسئولية.

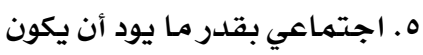

رابعاً: مهارة حل المشكلات واتخاذ القرار. وتتضمن المؤشرات الفرعية التالية:

$$
\text { ا ب بحدد المشكلة بوضوح. }
$$

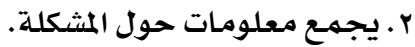

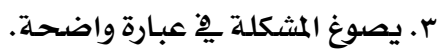

ع. يضع عدة حلول ممكنة للمشكلة.

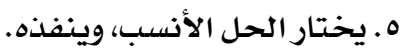

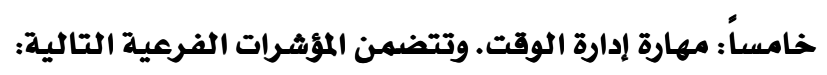

$$
\text { ا ـ يرتب الأهداف حسب الأولويـة. }
$$

r ب يضع جدول زمني لتنفيذ المهام المطلوبة.

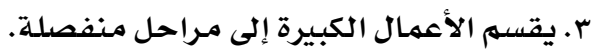

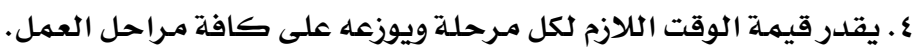




$$
\text { ه . ينفذ خطة إدارة الوقت ويقيمها. }
$$

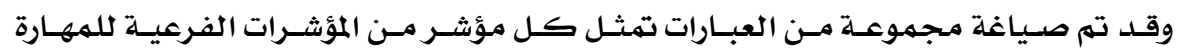

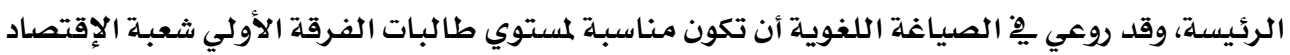

\section{طريقة تصحيح البطاقة:}

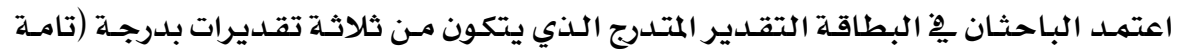

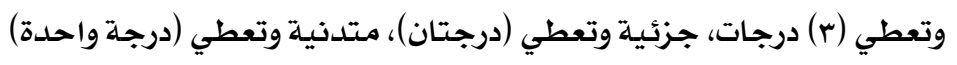

\section{صدق البطاقة: ودائ}

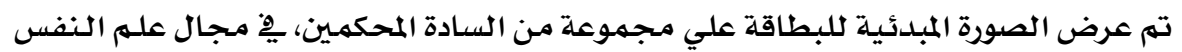

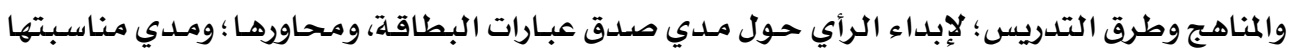

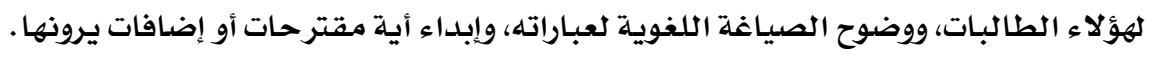

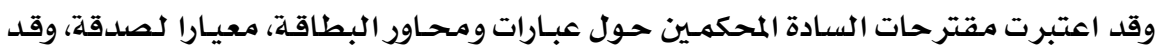

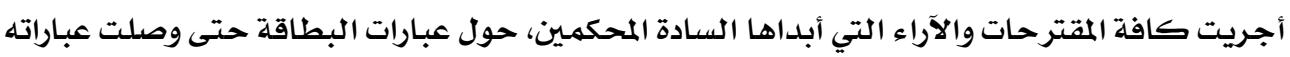

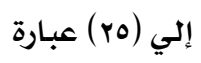

ثبات البطاقة:

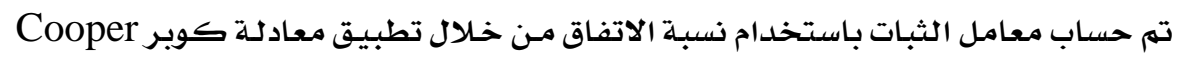

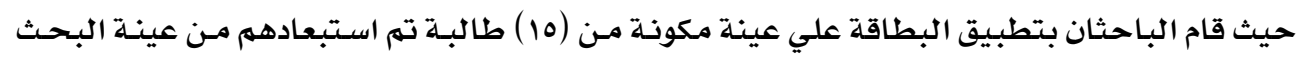

\begin{tabular}{|c|c|c|c|c|c|}
\hline نسبة الثبات & المجموع & عدد مرات علدم الاتفاق & علد مرات الاتفاق & المؤشرات & المهارة \\
\hline$\% 9 r$ & 10 & 1 & is & 0 & الاتصال والتواصل \\
\hline$\%$ \% & 10 & $r$ & ir & 0 & معرفة الذات \\
\hline$\% 9 r$ & 10 & 1 & $1 \varepsilon$ & 0 & المشاركة وتحمل المسئولية \\
\hline$\%$. & 10 & $r$ & ir & 0 & حل الشككلات واتخاذ القرار \\
\hline$\% a r$ & 10 & 1 & $1 \xi$ & 0 & إدارة الوقت \\
\hline$\% \wedge 4$ & 10 & r & ir & ro & المهارات (ككل) \\
\hline
\end{tabular}

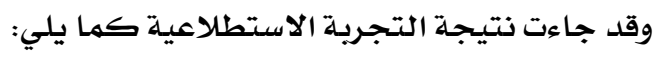

زمن تطبيق البطاقة:

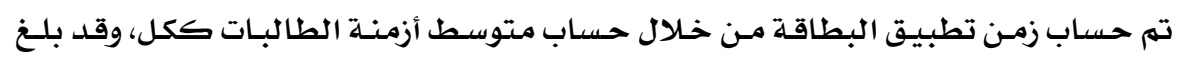

$$
\text { زمن تطبيقها (r. ا ) دقيقة. }
$$


بعد اطمئنان الباحثان علي صدق وثبات البطاقـة، وصـلاحيتها للتطبيق، علسي طالبـات عينـة

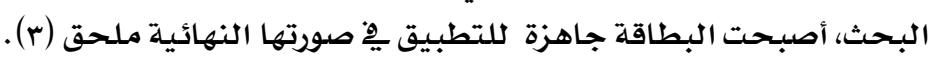

إجراءات البحث:

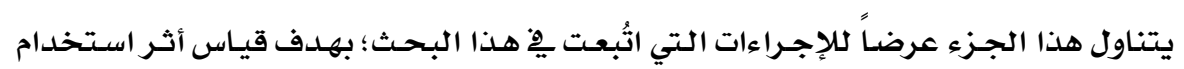

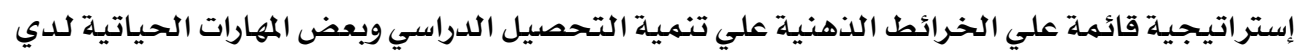

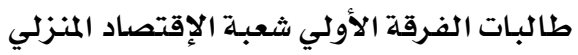

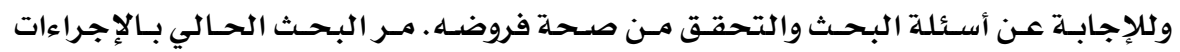
التاليـة:

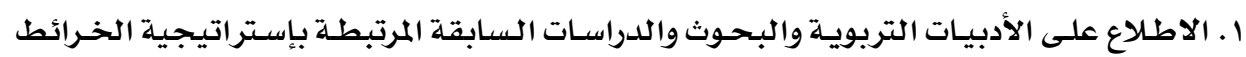

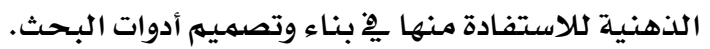

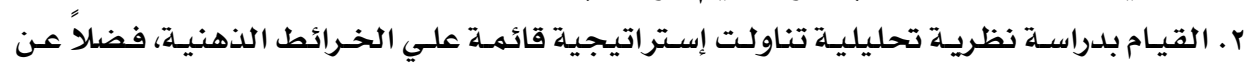

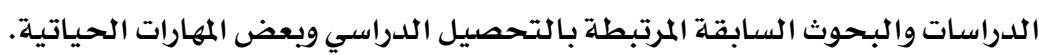

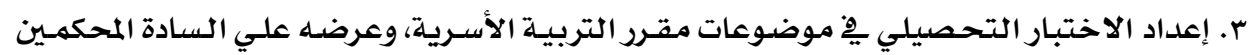
الإجراء التعديلات المقترحة وحساب صدقار الإديه وثباته.

ع. إعداد بطاقة ملاحظة لبعض المهارات التعلات المقترحةوحساباتية.

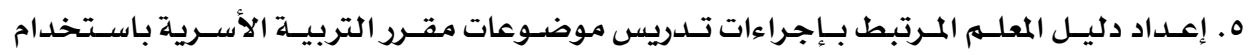

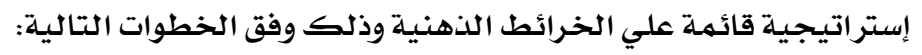

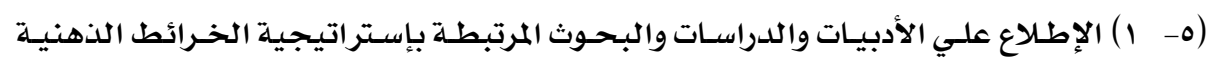
وتطبيقاتها يْ مجال الإقتصاد المنزلي.

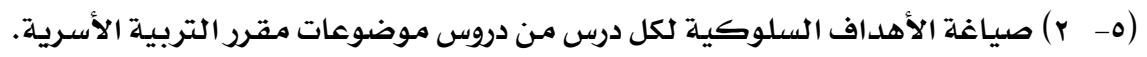
وقد اشتمل الدليل علي:

• إرشادات الدليل ويشمل التعريف، وكيفية السير ِِّْ تنفيذ التجريـة.

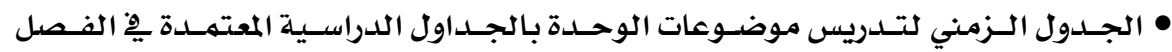

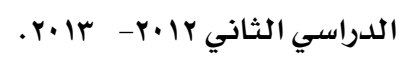

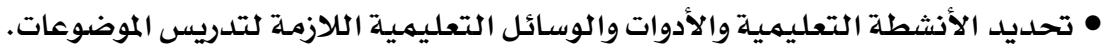

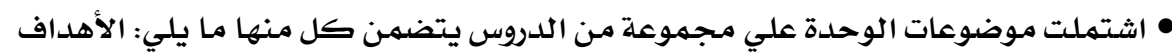

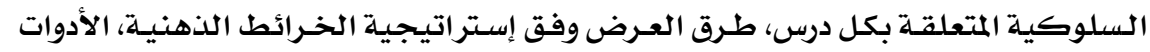

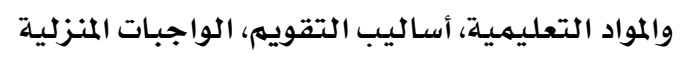

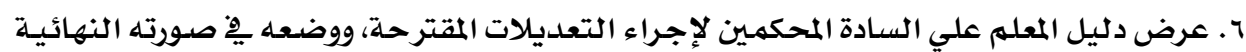


ב-2.

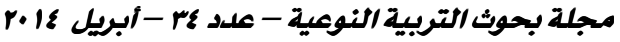

V. اختيار عينة الدراسة من طالبات الفرقة الأولي شعبة اقتصاد منزلي، وتقسيهها إلي مجموعتين

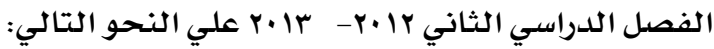

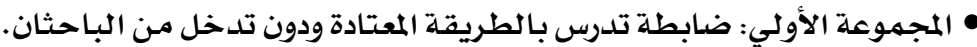

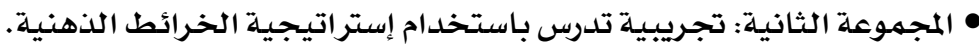

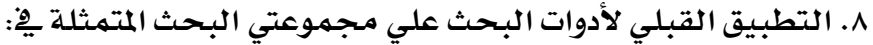

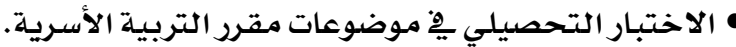
• بطاقة ملاحظة المهارات الحياتية ومؤشراتها الفرعية. موضواتئ. 9 ـ تجانس مجموعات البحث

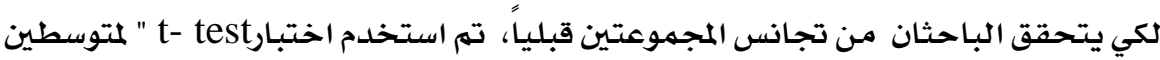

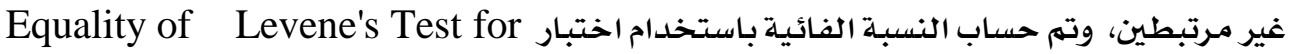
Variances جدول (ج) يوضح دلالة الفروق بين متوسطي درجات المجموعتين التجريبية والضابطة ِِّ التطبيق القبلي علي اختبار التحصيل الدراسي وبطاقة ملاحظة لبعض المهارات الحياتية

\begin{tabular}{|c|c|c|c|c|c|c|c|}
\hline مستوي الدلالة & قيمة "ت" & قيمة "ف" & درجة الحرية & الانحراف المعياري & المتوسط & المجموعة & الأداة \\
\hline \multirow{2}{*}{ غير دالة } & \multirow{2}{*}{, vrq } & \multirow{2}{*}{ •, एव६ } & \multirow{2}{*}{$\leqslant \wedge$} & $\xi, \cdot r$ & rr,0T & التجريبية & \multirow{2}{*}{ اختبار التحصيل } \\
\hline & & & & $r, q r$ & $r r, 7 \varepsilon$ & الضابطة & \\
\hline \multirow{2}{*}{ غير دالة } & \multirow{2}{*}{ •,rrI } & \multirow{2}{*}{$\bullet, \cdot \bullet$} & \multirow{2}{*}{$\wedge$} & $\{, 71$ & $r q, r r$ & التجريبية & \multirow{2}{*}{ بطاقة ملاحظة الحارة الحياتية } \\
\hline & & & & $\xi$, or & $r \cdot, r \cdot$ & الضابطة & \\
\hline
\end{tabular}

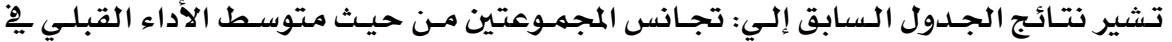

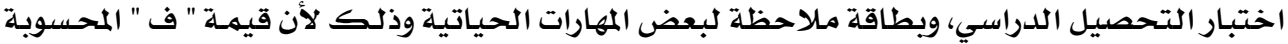

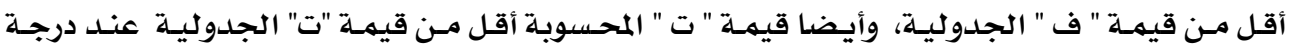

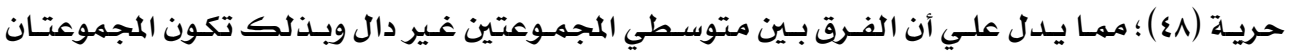

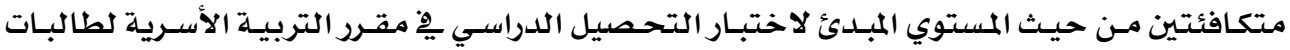

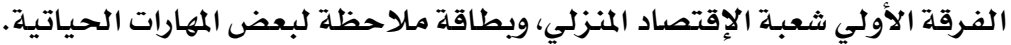
•l.

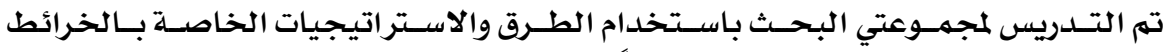

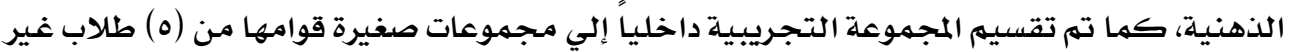

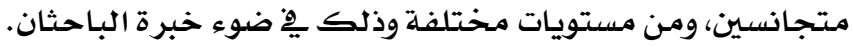




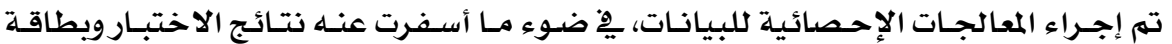

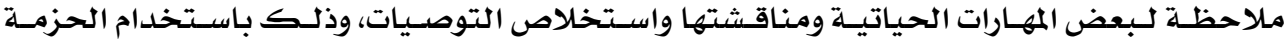

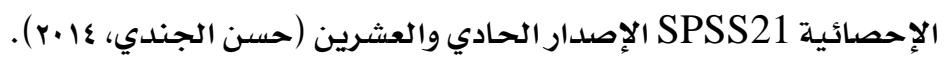
مناقشة النتائج التي توصل إليها البحث: ا. للإجابة عن السؤال الأول من أسئلة البحث والذي ينص علي: ما التصور المقترح للإسـتر اتيجية

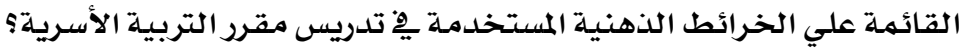

تتطلب الإجابـة عـن ذلـك السؤال إتبـاع الإجـراءات المحسددة التاليـة وتم توضـحيها ِِِ دليـل

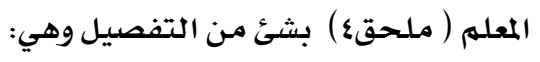

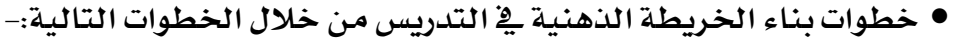

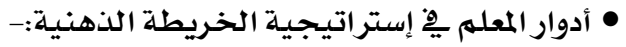

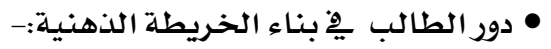

\begin{tabular}{|c|c|}
\hline \multicolumn{2}{|c|}{ خرائط الذهنية) وهر } \\
\hline 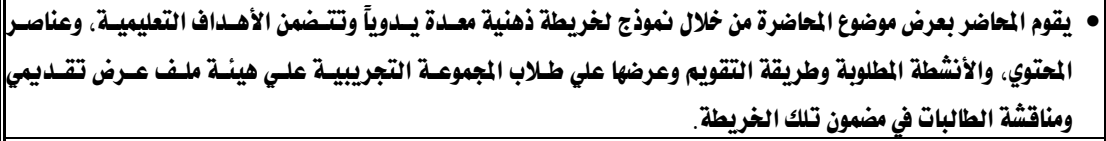 & | المرحلة الأولي: \\
\hline • • يقوم المحاضر بإثارة الطالبات لتوليد أفكار متضمنة لموضوع المحاضرة، ثم يقدم الخريطة الذهنيـة لشرح الموضـوع والأفكار & المرحلة الثانية: \\
\hline 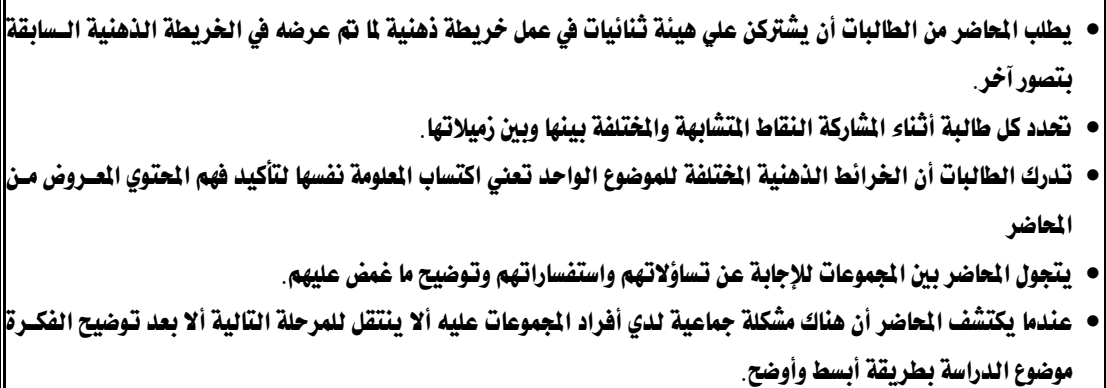 & فكر - زاوج - المرحلة الثاثة: \\
\hline • • • ينادي المحاضر علي كل زوج في كل مجموعة علي حلده ليشتركن مع الأزواج الأخرى بحيث يتشاورون في أشكال الخرائط الأكثر| & المرحلة الرابعة: \\
\hline 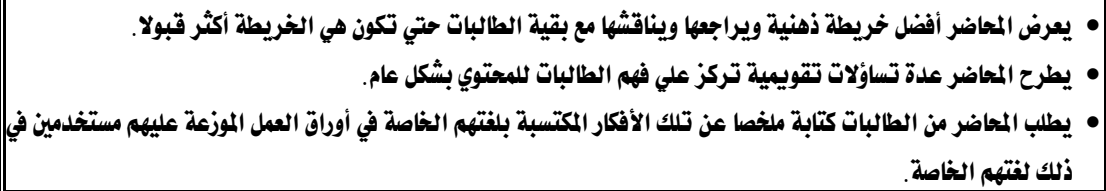 & المرحلة الخامسة \\
\hline
\end{tabular}

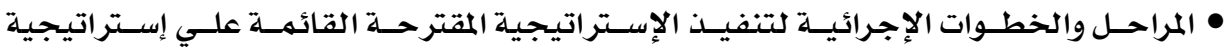




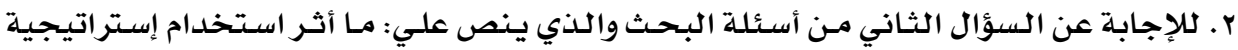

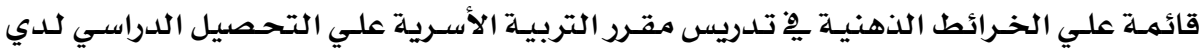

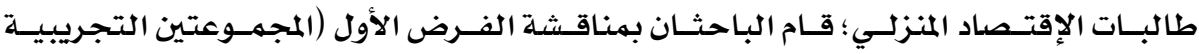

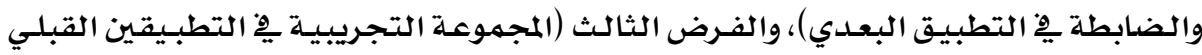

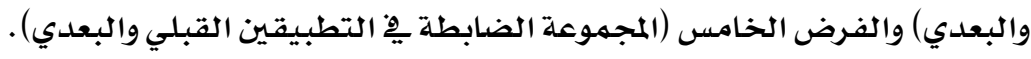

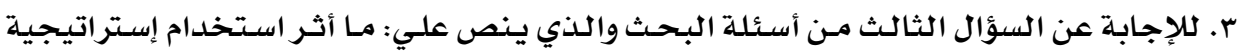

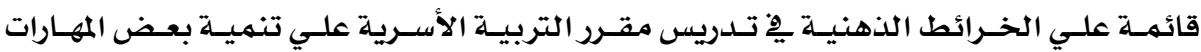

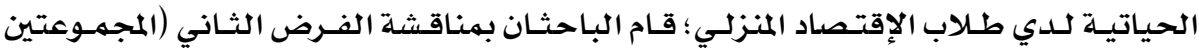

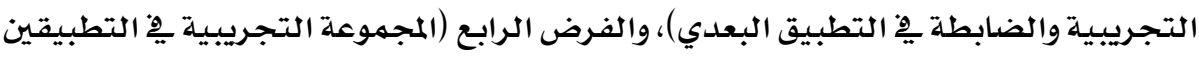

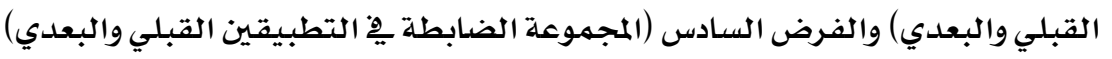

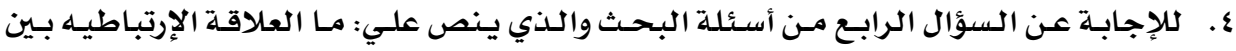

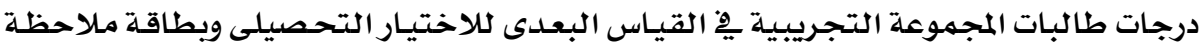

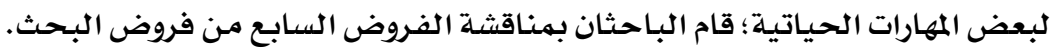
وفيما يلي عرض لهذه الفروض تفصيلاً:

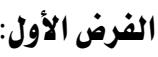

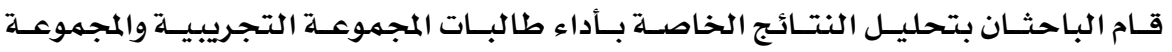

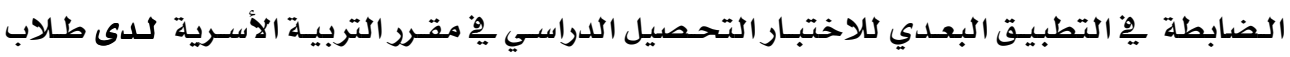

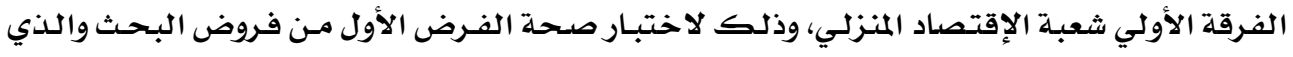

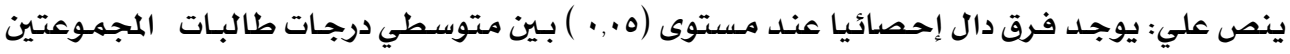

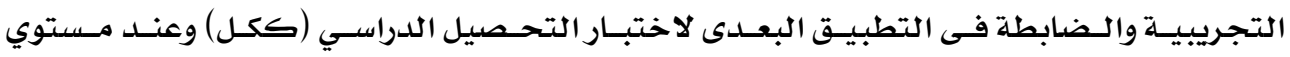
(التذكر، الفهم، التطبيق، التحليل). ولاختبـار صسحة هـذا الفـرض تم حسـاب (t-test لمتوسـطين غـير مـرتبطين) للمقارنـة بـين

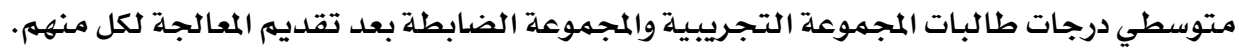


لص= تصميم إستراتيجية قائمة علي الخرائط النهنية وأثرها علي تنهية التحصيل اللراسي وبعض المهارات الحياتية

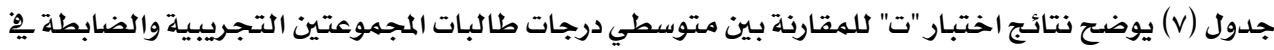

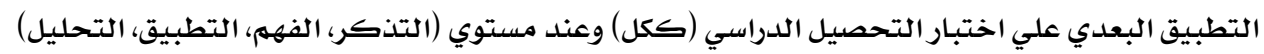

\begin{tabular}{|c|c|c|c|c|c|c|c|c|}
\hline حجم التأثير & مستوي & قيمة "ت" & الحرجة & الالمحراف & التوسط & علداد & المجموعة & المستوى \\
\hline \multirow{2}{*}{ •, वr } & \multirow[t]{2}{*}{ دالة } & \multirow{2}{*}{ YY, YY } & \multirow{2}{*}{$\wedge$} & 1,87 & $19, \cdot 1$ & ro & التجريبية & \multirow{2}{*}{ التذكر } \\
\hline & & & & $1, \cdot 0$ & $9, Y \xi$ & ro & الضابطة & \\
\hline \multirow{2}{*}{ •, बr } & \multirow{2}{*}{ دالة } & \multirow{2}{*}{$r r, \Lambda \cdot$} & \multirow{2}{*}{$\Lambda$} & $1, n$ & $\mid \mathrm{A}, \xi \mathrm{A}$ & ro & التجريبية & \multirow{2}{*}{ الفهه } \\
\hline & & & & $1,1 \varepsilon$ & $\Lambda, 7 \Lambda$ & ro & الضابطة & \\
\hline \multirow{2}{*}{ r } & \multirow{2}{*}{ دالة } & \multirow{2}{*}{$9, r r$} & \multirow{2}{*}{$\Lambda$} & •, Tr & $9, \mathrm{rA}$ & ro & التجريبية & \multirow{2}{*}{ التطبيق } \\
\hline & & & & 1,ro & $r, \Sigma \wedge$ & ro & الضابطة & \\
\hline \multirow{2}{*}{$\cdot, \mathrm{v} \cdot$} & \multirow{2}{*}{ دالة } & \multirow{2}{*}{$1 \cdot, 77$} & \multirow{2}{*}{$\Lambda$} & •, r. & $7,7 \xi$ & ro & التجريبية & \multirow{2}{*}{ التحليل } \\
\hline & & & & $1, r r$ & $r, \eta \xi$ & ro & الضابطة & \\
\hline \multirow{2}{*}{$\cdot, 90$} & \multirow{2}{*}{ دالة } & \multirow{2}{*}{ rr, rq } & \multirow{2}{*}{$\varepsilon \wedge$} & $r, \xi r$ & $0,\{\AA$ & ro & التجريبية & \multirow{2}{*}{ الاختبار (ككل) } \\
\hline & & & & $r, \bullet \wedge$ & $r_{0,0 \xi}$ & ro & الضابطة & \\
\hline
\end{tabular}

*دالة عند مستوي 0 .,

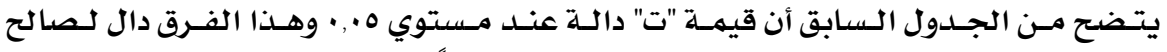

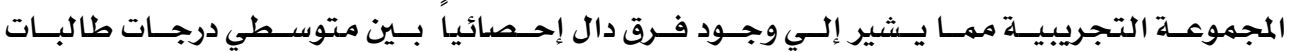

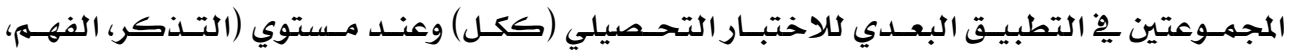

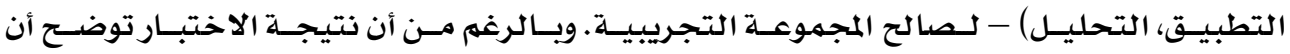

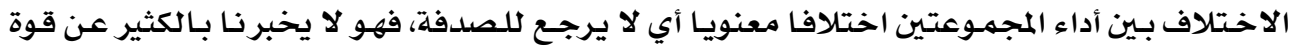

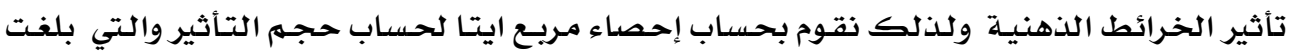

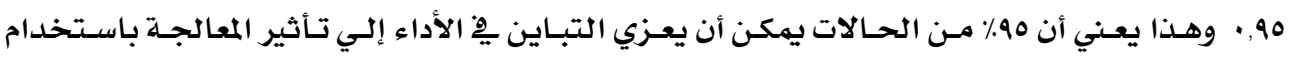

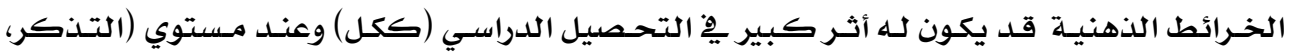
الفهم، التطبيق، التحليل).

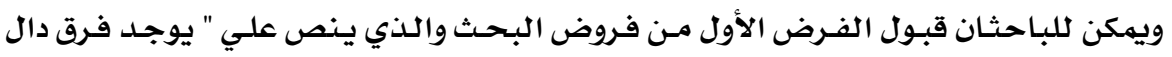

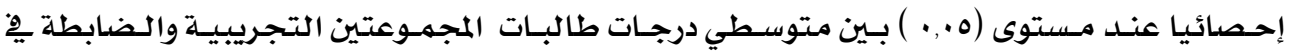

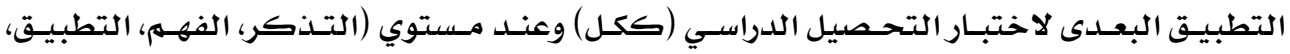

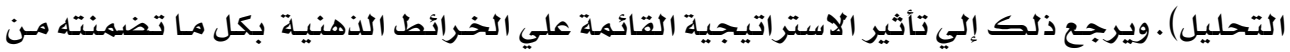

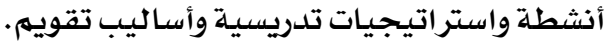




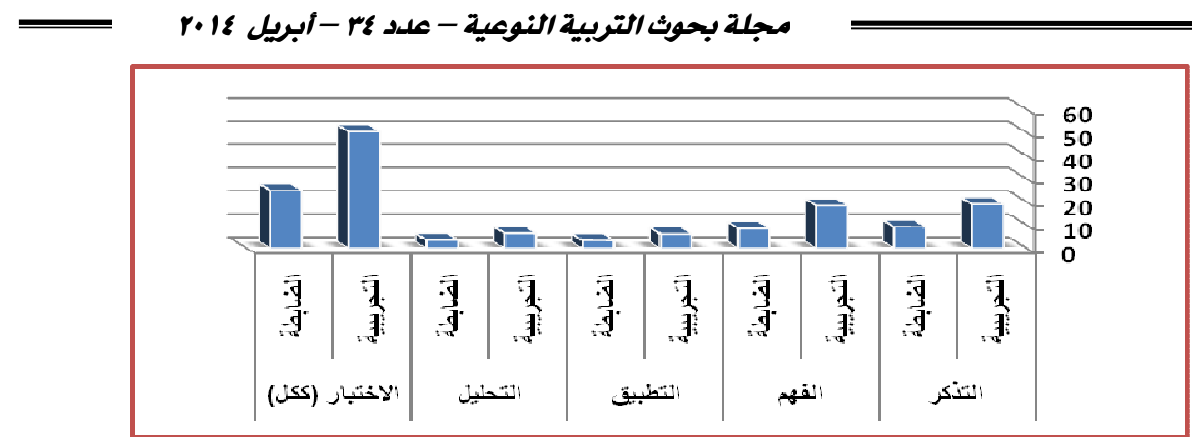

شكل (1) متتوسط درجات طالبات المجموعتين التجريبية والمجموعة الضابطة يِّ التطبيق البعدي علي اختبار التحصيل الدراسي (ككل) وعند مستوي (التذكر، الفهم، التطبيق، التحليل)

الثرض الثاذي

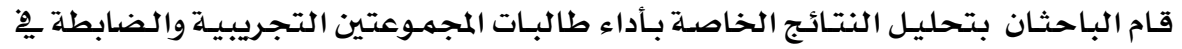

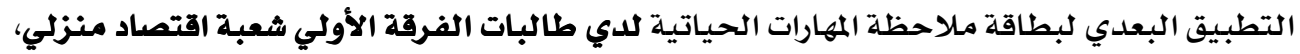

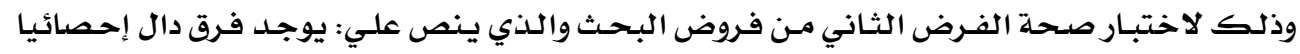

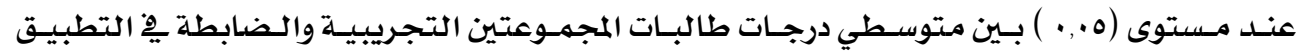

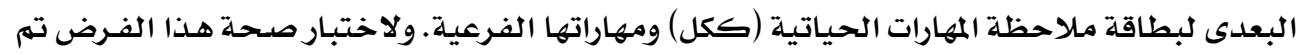

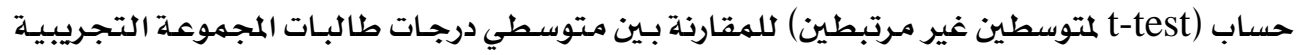
والمجموعة الضابطة بعد تقديهم المعالجـة لكل منهمه.

جلدول (^) يوضتح نتائج اختبار "ت" للمقارنة بين المتوسطين البعدي لدرجات طالبات المجموعتين التجريبية والضابطة علي بطاقة ملاحظة المهارات الحياتية (ككل) ومهاراتها الفرعية

\begin{tabular}{|c|c|c|c|c|c|c|}
\hline حجم التأثير & مستوي & "تيمة & الانحراف & المتوسط & المجموعة & المهارات \\
\hline \multirow{2}{*}{ •, Vr } & \multirow{2}{*}{ دالة } & \multirow{2}{*}{ rr.ll } & .9 .1 & VI.Ir & التجريبية & \multirow{2}{*}{ الاتصال والتواصل } \\
\hline & & & $19 . r$ & $r \cdot . V$ & الضابطة & \\
\hline \multirow{2}{*}{$\cdot, \wedge \cdot$} & \multirow{2}{*}{ دالة } & \multirow{2}{*}{ Ir.18 } & $\wedge \wedge . \cdot$ & 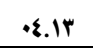 & التجريبية & \multirow{2}{*}{ معرفة الذات } \\
\hline & & & $.0 . r$ & Vr. & الضابطة & \\
\hline \multirow{2}{*}{$\cdot, \wedge \xi$} & \multirow{2}{*}{ دالة } & \multirow{2}{*}{91.10} & qr.P & Ir.Ir & التجريبية & \multirow{2}{*}{ حل المشكلات واتخاذ القرار } \\
\hline & & & $\xi \cdot .1$ & YA.V & الضابطة & \\
\hline \multirow{2}{*}{$\cdot, 19$} & \multirow{2}{*}{ دالة } & \multirow{2}{*}{ \&०.r. } & r1.1 & $17.1 \%$ & التجريبية & \multirow{2}{*}{ المشاركة وتحمل المسئولية } \\
\hline & & & rA.I & 94.0 & الضابطة & \\
\hline \multirow{2}{*}{$\cdot, n$} & \multirow{2}{*}{ دالة } & \multirow{2}{*}{$11, \cdot 0$} & $r . .1$ & rA.IT & التجريبية & \multirow{2}{*}{ إدارة الوقت } \\
\hline & & & $r 9.1$ & or. 7 & الضابطة & \\
\hline \multirow{2}{*}{$\cdot, 9 \xi$} & \multirow{2}{*}{ دالة } & \multirow{2}{*}{ rv, ro } & 9ร.५ & 17.70 & التجريبية & \multirow{2}{*}{ المهارات (ككل) } \\
\hline & & & 91.8 & צร. & الضابطة & \\
\hline
\end{tabular}




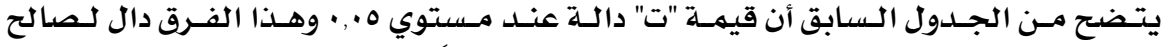

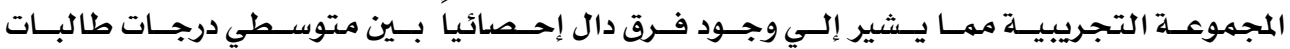

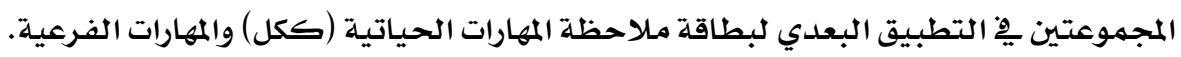

بالرغم من أن نتيجة الاختبار توضح أن الاختلاف بين أداء المجموعتين اختلافا معنويا أي لا لا

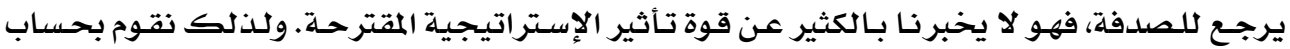

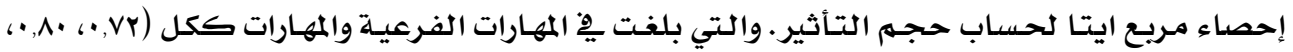

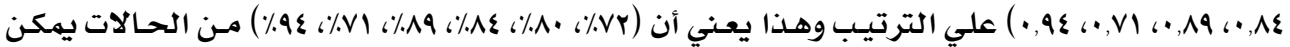

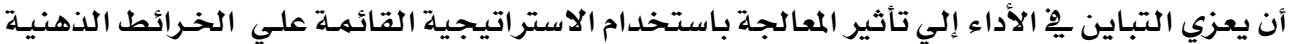
قد يكون له أثر كبير يْ تنمية المهارات الحياتية.

ويمكن للباحثان قبول الفرض الثاني مـن فروض البحثث والذني يــــ علدي " يوجـد فـرق دال

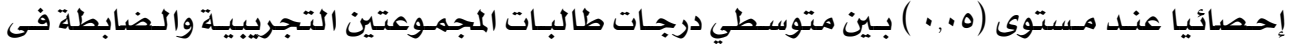

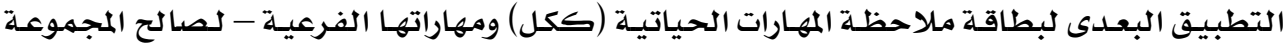

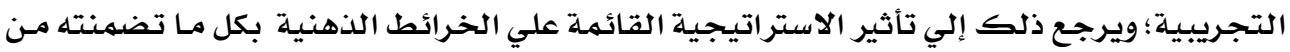
أنشطة واستراتيجيات تدريسية وأساليب تقويه.

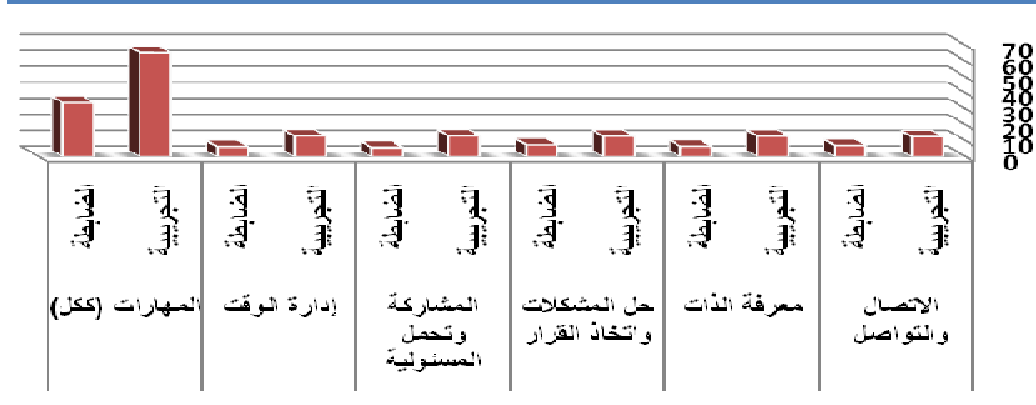

شكل (r) متوسط درجات طالبات المجموعة التجريبية والمجموعة الضابطة ِِّ التطبيق البعدي علي بطاقة ملاحظة المهارات الحياتية (ككل) ومهاراتها الفرعية.

الفرض الثالث للبحث:

قـام الباحثـان بتحليـل النتـائج الخاصـة بـأداء طالبـات المجموعـة التجريبيـة يِّ التطبـيقين

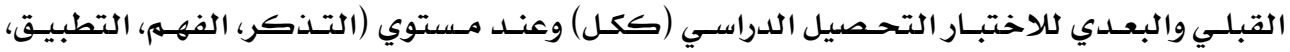

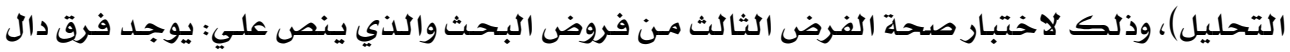

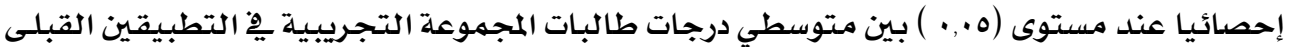

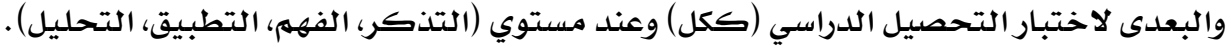
ولاختبار صحة هذا الفرض تم حساب (t-test لمتوسطين مرتبطين) للمقارنـة بـين متوسطي درجات طالبات المجموعة التجريبية قبل وبعد تقديهم الاستراتيجية القائمة علي الخرائط الذهنية. 
مجلة بحوث التربية النوعية - علد غr - أبريل

جدول (ه) يوضح نتائج اختبار "ت" للمقارنة بين المتوسطين القبلي والبعدي لدرجات طالبات المجموعة

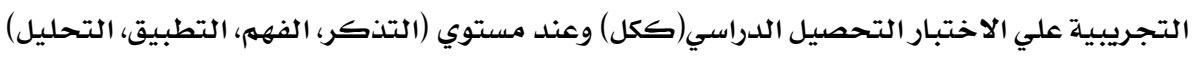

\begin{tabular}{|c|c|c|c|c|c|c|c|}
\hline حجم التأثير & مستوي & قيمة "ت" & العرجة & الانحراف & التتوسط & التطبيق & المستوى \\
\hline \multirow{2}{*}{ - 97} & \multirow{2}{*}{ دالة } & \multirow{2}{*}{$Y \xi, 9 \uparrow$} & \multirow{2}{*}{ Y } & $1, r r$ & $\Lambda, 9 r$ & قبلي & \multirow{2}{*}{ التذكر } \\
\hline & & & & 1,87 & $19, \cdot 1$ & بعدي & \\
\hline \multirow{2}{*}{$\cdot, 97$} & \multirow{2}{*}{ دالة } & \multirow{2}{*}{ ro,Ar } & \multirow{2}{*}{ Y } & 1,10 & $\Lambda,\{\wedge$ & قبلي & \multirow{2}{*}{ الفهم } \\
\hline & & & & $1, n$ & $\mid A, \leqslant A$ & بعدي & \\
\hline \multirow{2}{*}{ •,AT } & \multirow{2}{*}{ دالة } & \multirow{2}{*}{$1 \cdot, \wedge 7$} & \multirow{2}{*}{ Yq } & 1,89 & $r, \wedge \varepsilon$ & قبلي & \multirow{2}{*}{ التطبيق } \\
\hline & & & & •, Tr & $7, \mathrm{r \Lambda}$ & بعدي & \\
\hline \multirow{2}{*}{$\cdot, \wedge 9$} & \multirow{2}{*}{ دالة } & \multirow{2}{*}{ Ir,or } & \multirow{2}{*}{ Y } & 1,87 & r, rY & قبلي & \multirow{2}{*}{ التحليل } \\
\hline & & & & , v. & $7,7 \xi$ & بعدي & \\
\hline \multirow{2}{*}{$\cdot, 9 v$} & \multirow{2}{*}{ دالة } & \multirow{2}{*}{ rq, ૧. } & \multirow{2}{*}{$r \varepsilon$} & $\varepsilon, \bullet r$ & rr,0T & قبلي & \multirow{2}{*}{ (كل) الاختبار } \\
\hline & & & & $r, \xi r$ & $0, \$ \wedge$ & بعدي & \\
\hline
\end{tabular}

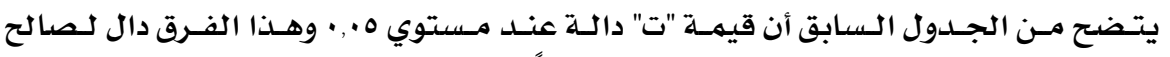

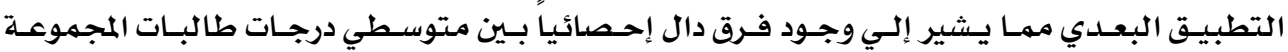

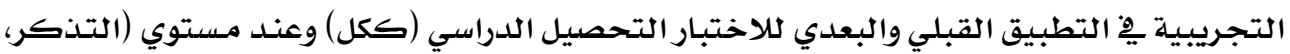

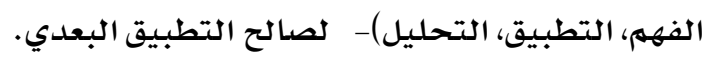

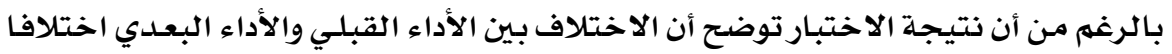

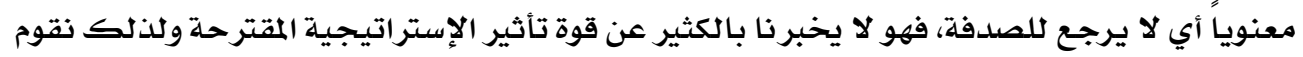

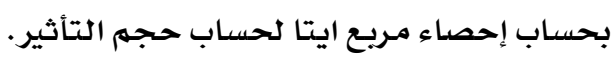

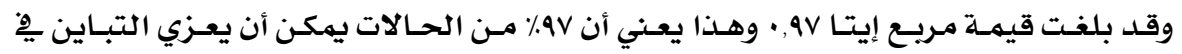

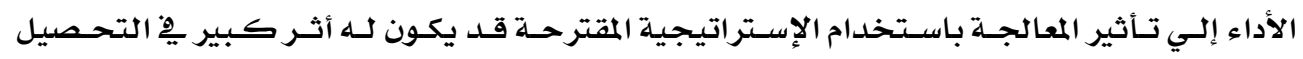

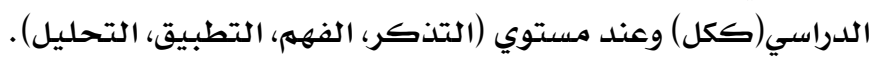

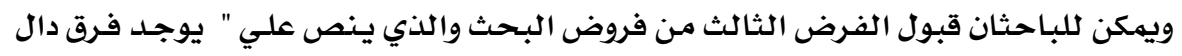

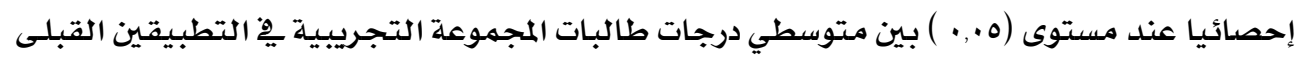

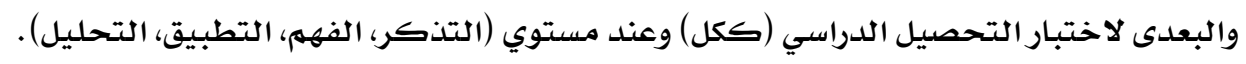

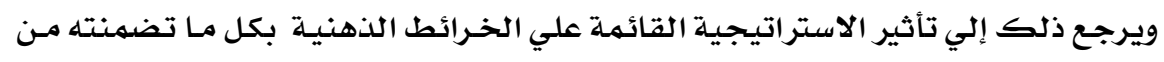

أنثطة واستراتيجيات تدريسية وأساليب تقويم. 


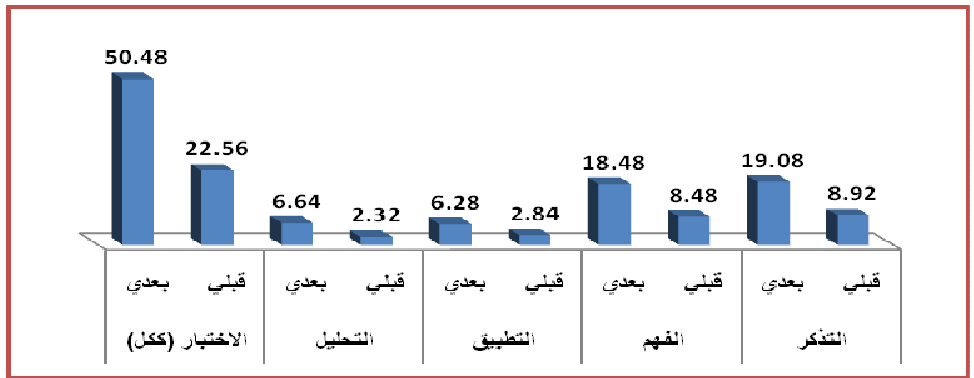

شكل (r) متوسط درجات طالبات المجموعة التجريبية ِِّ التطبيقين القبلي والبعدي علي اختبار التحصيل(ككل) وعند مستوي (التذكر، الفهم، التطبيق، التحليل).

الثرض الرابع للبحث:

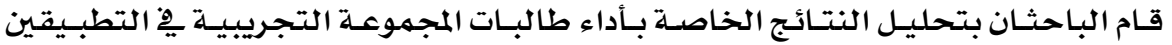

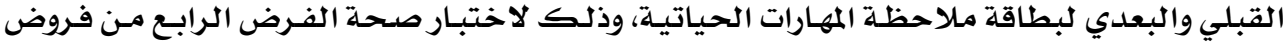

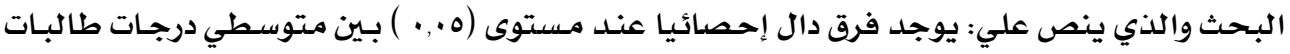

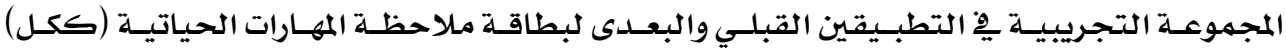
ومهاراتها الفرعية.

ولاختبار صحة هذا الفرض تم حساب (t-test لمتوسطين مرتبطين) للمقارنـة بـين متوسطي درجات طالبات المجموعة التجريبية قبله هدل وبعد الإستراتيجية المقترحلة. جدول ( . ) يوضح نتائج اختبار "ت" للمقارنة بين المتوسطين القبلي والبعدي لدرجات طالبات المجموعة

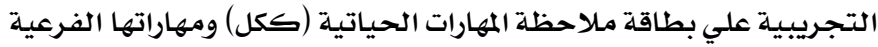

\begin{tabular}{|c|c|c|c|c|c|c|}
\hline حجم التأثير & مستوي & قيمة "ت" & الانحراف & المتوسط & التطبيق & المهارات \\
\hline \multirow{2}{*}{ •, qr } & \multirow{2}{*}{ دالة ل } & \multirow{2}{*}{ IV,rr } & 1,77 & $0, \mathrm{VI}$ & قبلي & \multirow{2}{*}{ الاتصال والتواصل } \\
\hline & & & $1, \cdot 9$ & $1 r, v q$ & بعدي & \\
\hline \multirow{2}{*}{$\cdot, 90$} & \multirow{2}{*}{ دالة ل } & \multirow{2}{*}{ rr, ro } & $1, r \wedge$ & $0, \mathfrak{\xi}$ & قبلي & \multirow{2}{*}{ معرفة الذات } \\
\hline & & & $\cdot, \wedge \wedge$ & $\| \pi, \cdot \xi$ & بعدي & \\
\hline \multirow{2}{*}{ •, q4 } & \multirow{2}{*}{ 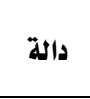 } & \multirow{2}{*}{$M A, \cdot V$} & $1, \xi \Psi$ & 7,71 & قبلي & \multirow{2}{*}{ حل الشكلات واتخاذ } \\
\hline & & & $\cdot, 9 \mathrm{~V}$ & $\mid r, I r$ & بعدي & \\
\hline \multirow{2}{*}{ •,ar } & \multirow{2}{*}{ دالة ل } & \multirow{2}{*}{$|v, 7|$} & $1, \mathrm{rA}$ & 0,71 & قبلي & \multirow{2}{*}{ المشاركة وتحمل } \\
\hline & & & $1, r)$ & 17,17 & بعدي & \\
\hline \multirow{2}{*}{ •,१६ } & \multirow{2}{*}{ 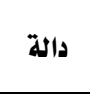 } & \multirow{2}{*}{19,79} & 1,09 & 7,17 & قبلي & \multirow{2}{*}{ إدارة الوقت } \\
\hline & & & $1, r$. & $\mid r, r A$ & بعدي & \\
\hline \multirow{2}{*}{$\cdot, q \gamma$} & \multirow{2}{*}{ 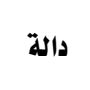 } & \multirow{2}{*}{$r r, A T$} & $\{, \eta 1$ & $r q, r r$ & قبلي & \multirow{2}{*}{ المهارات (ككل) } \\
\hline & & & r,१६ & $70, r 9$ & بعدي & \\
\hline
\end{tabular}




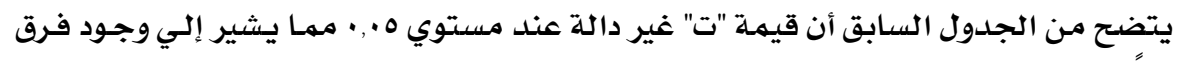

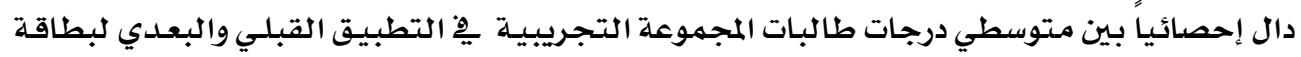

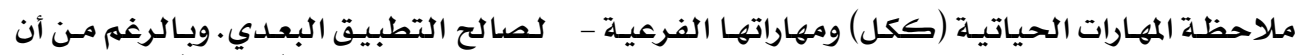

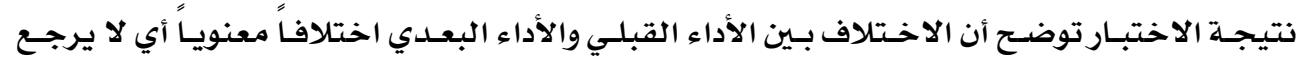

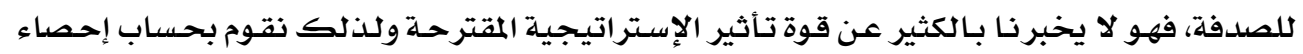

$$
\text { مريع ايتا لحساب حجم التأثير. }
$$

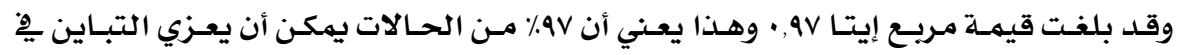

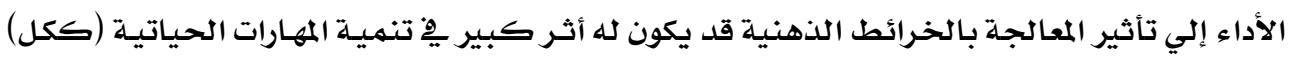

ومهاراتها الفرعية.

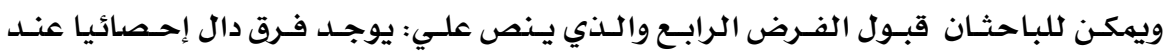

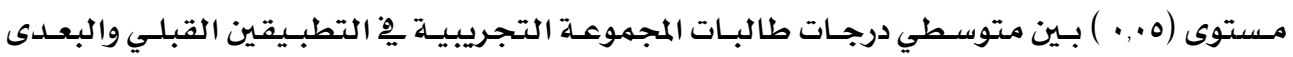

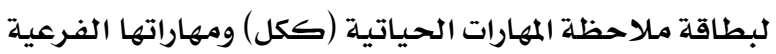

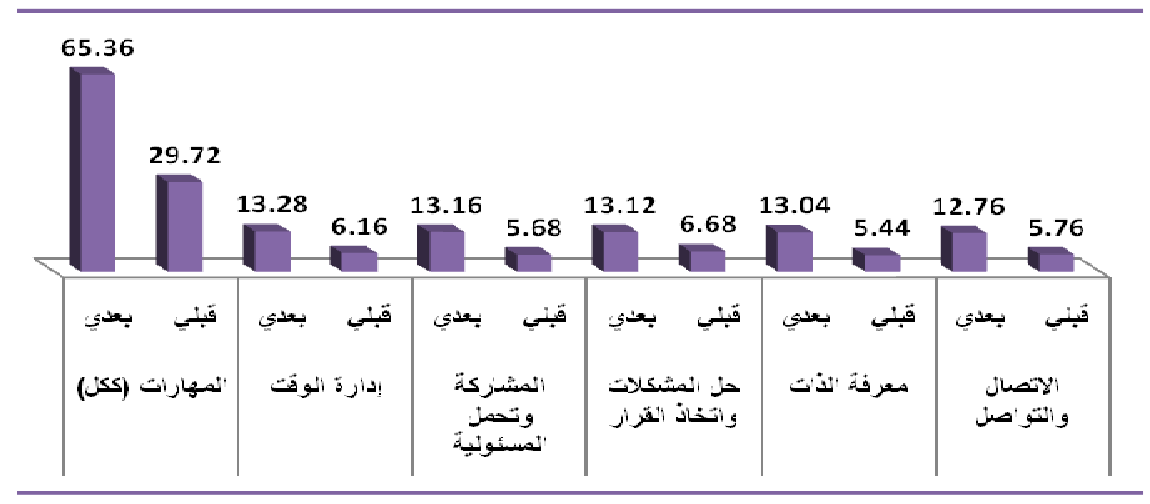

شكل (ع ) متوسط درجات طالبات المجموعة التجريبية يِّ التطبيقين القبلي والبعدي علي بطاقة ملاحظة المهارات الحياتية (ككل) ومهاراتها الفرعية.

الفرض الخامس للبحث:

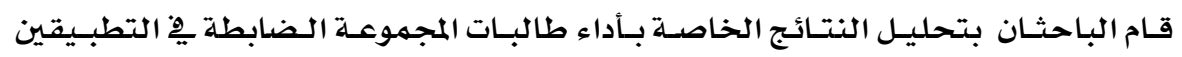

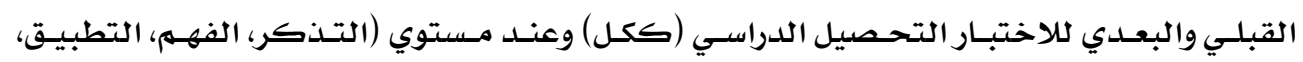

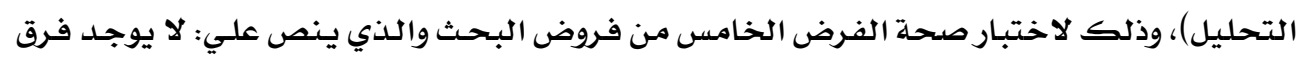

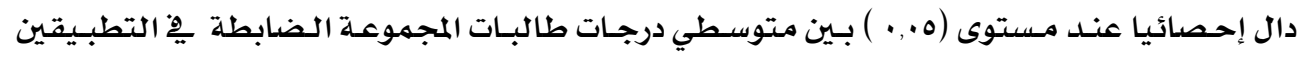

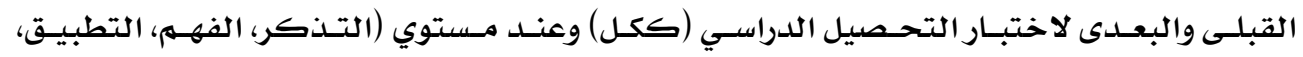
التحليل) القبلئ

ولاختبار صحة هذا الفرض تم حساب (t-test لمتوسطين مرتبطين) للمقارنة بـين متوسطي درجات طالبات المجموعة الضابطة قبل وبعد تقديهم التدريس التقليدي. 
لـ تصميه إستراتيجية قائمة علي الخرائط النهنية وأثرها علي تنهية التحصيل الدراسي ويعض المهارات الحياتية

جدول (11) يوضح نتائج اختبار "ت" للمقارنة بين المتوسطين القبلي والبعدي لدرجات طالبات المجموعة

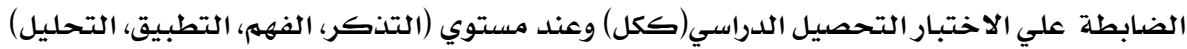

\begin{tabular}{|c|c|c|c|c|c|c|c|}
\hline حجم التأثير & مستوي & قيمة "ت" & درجة الحرية & الانحراف & التوسط & التطبيق & المستوى \\
\hline \multirow{2}{*}{ • } & \multirow{2}{*}{ غير دالة } & \multirow{2}{*}{$r, q 1$} & \multirow{2}{*}{ Yq } & $1, \cdot 9$ & $\Lambda, 7 \Lambda$ & قبلي & \multirow{2}{*}{ التذكر } \\
\hline & & & & $1, \cdot 0$ & $9, Y \xi$ & بعدي & \\
\hline \multirow{2}{*}{$\bullet, \bullet \xi$} & \multirow{2}{*}{ غير دالة } & \multirow{2}{*}{ 1,.• } & \multirow{2}{*}{ Y } & 1,11 & $\Lambda, 7$ & قبلي & \multirow{2}{*}{ الفهم } \\
\hline & & & & $1,1 \varepsilon$ & $\Lambda, 7 \Lambda$ & بعدي & \\
\hline \multirow{2}{*}{$\cdot, r \cdot$} & \multirow{2}{*}{ غير دالة } & \multirow{2}{*}{$r, \leqslant 9$} & \multirow{2}{*}{ Y } & $1, \S 1$ & $r, q r$ & قبلي & \multirow{2}{*}{ التطبيق } \\
\hline & & & & $1, r 0$ & $r, \$ \wedge$ & بعدي & \\
\hline \multirow{2}{*}{$\cdot, r q$} & \multirow{2}{*}{ غير دالة } & \multirow{2}{*}{$r, r}$. & \multirow{2}{*}{ Y } & $1, \mathrm{rA}$ & $r, \mathfrak{s \varepsilon}$ & قبلي & \multirow{2}{*}{ التحليل } \\
\hline & & & & $1, r r$ & $r, \eta \xi$ & بعدي & \\
\hline \multirow{2}{*}{$\bullet, \xi \bullet$} & \multirow{2}{*}{ غير دالة } & \multirow{2}{*}{$\xi, \bullet 1$} & \multirow{2}{*}{ Y६ } & $r, q r$ & $r r, 7 \varepsilon$ & قبلي & \multirow{2}{*}{ (ككل) الاختبار } \\
\hline & & & & $r, \bullet \wedge$ & $r_{0,0}, \xi$ & بعدي & \\
\hline
\end{tabular}

يتضح من الجدول السابق أن قيمة "ت" غير دالة عند مستوي ه. . • ممها يشير إلي عدم وجهود

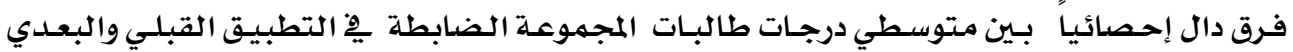
للاختبار التحصيل الدراسي (ككل) وعند مستوي (التذكر، الفهم، التطبيق، التحليل).

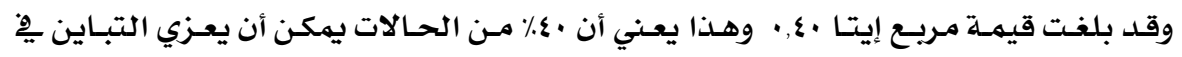

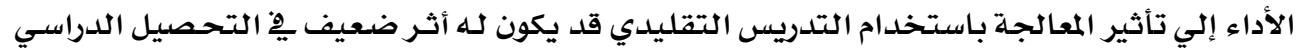
(ككل) وعند مستوي (التذكر، الفهم، التطبيق، التمعاد التحليل).

ويمكن للباحثان قبول الفرض الخـامس والـني ينص علدي: لا يوجـد فرق دال إحصائيا عند

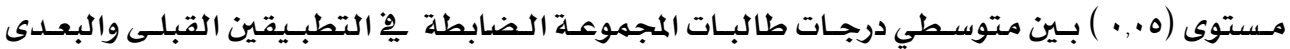

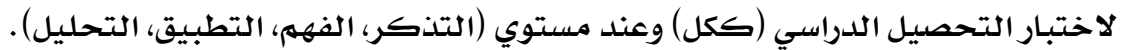

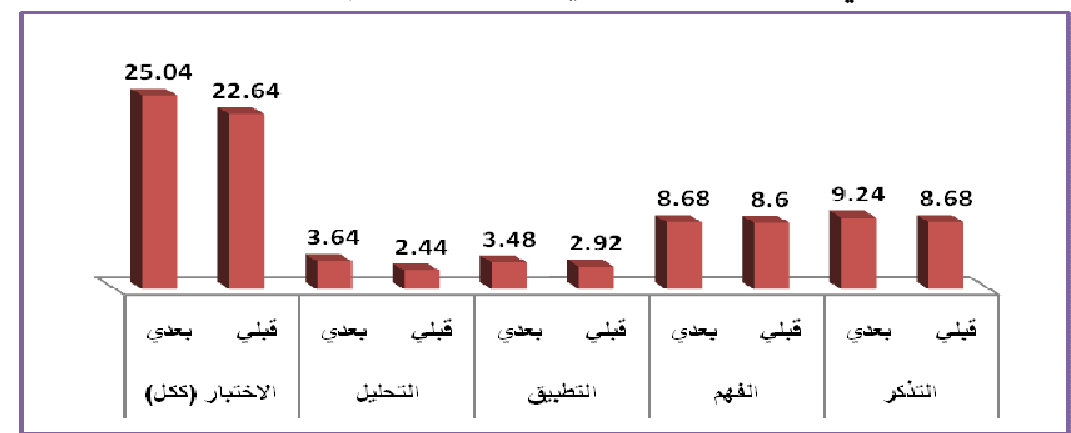

شكل (ه) متوسط درجات طالبات المجموعة الضابطة ِِِ التطبيقين القبلي والبعدي علي اختبار التحصيل(ككل) وعند مستوي (التذكر، الفهم، التطبيق، التحليل). 
الفرض السادس للبحث:

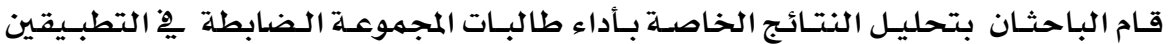
القبلي والبعدي لبطاقة ملاحظة المهارات الحياتية، وذلك لاختبار صحة الفرض السـادس مـن فروض

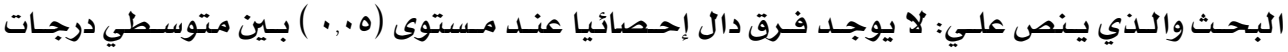

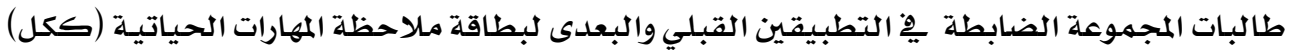
ومهاراتها الفرعية.

ولاختبار صحة هذا الفرض تم حساب (t-test لمتوسطين مرتبطين) للمقارنـة بـين متوسطي درجات طالبات المجموعة الضابطة قبل وبعد التدريس التقليدي. جدول (r ا ) يوضح نتائج اختبار "ت" للمقارنة بين المتوسطين القبلي والبعدي لدرجات طالبات المجموعة

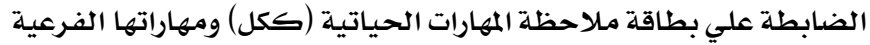

\begin{tabular}{|c|c|c|c|c|c|c|}
\hline حجم التأثير & مستوي الدلالة & قيهة "ت" & الانحراف & المتوسط & التطبيق & المهارات \\
\hline \multirow{2}{*}{ •, $\boldsymbol{k}$} & \multirow{2}{*}{ غير دالة } & \multirow{2}{*}{$r, \Lambda}$. & $1, \mathrm{v}$. & $0, \Lambda$. & قبلي & \multirow{2}{*}{ الاتصال والتواصل } \\
\hline & & & $r, 19$ & $v, r_{*}$ & بعدي & \\
\hline \multirow{2}{*}{ •, 19} & \multirow{2}{*}{ غير دالة } & \multirow{2}{*}{$r, r q$} & $1, \xi V$ & 0,07 & قبلي & \multirow{2}{*}{ معرفة الذات } \\
\hline & & & $r, \cdot 0$ & T,VY & بعدي & \\
\hline \multirow{2}{*}{ • } & \multirow{2}{*}{ غير دالة } & \multirow{2}{*}{$r, Y$} & $1, r \varepsilon$ & $\Upsilon, \wedge \varepsilon$ & قبلي & \multirow{2}{*}{ حل الشكلات واتخاذ } \\
\hline & & & $1,8 \cdot$ & $v, 71$ & بعدي & \\
\hline \multirow{2}{*}{$\cdot, \cdot \vee$} & \multirow{2}{*}{ غير دالة } & \multirow{2}{*}{1, ro } & 1, ro & $0, \Lambda$. & قبلي & \multirow{2}{*}{ المشاركة وتحمل } \\
\hline & & & $1, \mathrm{rA}$ & 0,94 & بعدي & \\
\hline \multirow{2}{*}{$\cdot, r$} & \multirow{2}{*}{ غير دالة } & \multirow{2}{*}{$r, 00$} & 1,00 & $9, r_{.}$ & قبلي & \multirow{2}{*}{ إدارة الوقت } \\
\hline & & & $1, r q$ & I,or & بعدي & \\
\hline \multirow{2}{*}{ •, rr } & \multirow{2}{*}{ غير دالة } & \multirow{2}{*}{$r, A r$} & $\xi$, or & $r \cdot, r \cdot$ & قبلي & \multirow{2}{*}{ المهارات (ككل) } \\
\hline & & & $\{, 91$ & $r \xi, \bullet \xi$ & بعدي & \\
\hline
\end{tabular}

يتضح من الجدول السابق أن قيمة "ت" غير دالة عند مستوي ه . • ممها يشير إلي عدم وجهود

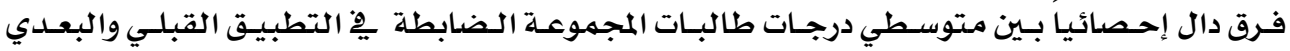
لبطاقة ملاحظة المهارات الحياتية (ككل) ومهاراتها الفرعية دورات

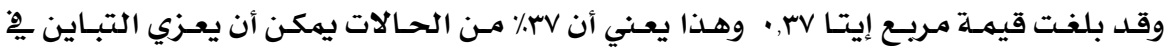

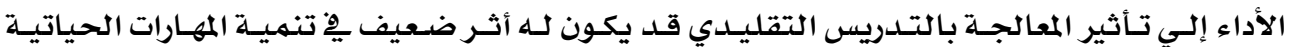
(ككل) ومهاراتها الفرعية.

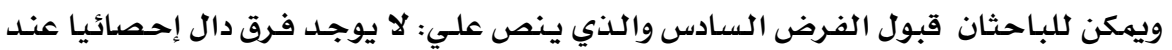

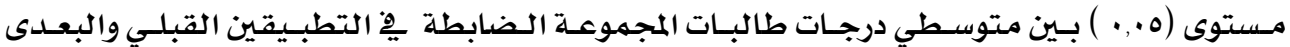
لبطاقة ملاحظة المهارات الحياتية (ككل) ومهاراتها الفرعية. 
لـ تصميم إستراتيجية قائمة علي الخرائط الذهنية وأثرها على تنمية التحصيل اللراسي وبعض المهارات الحياتية

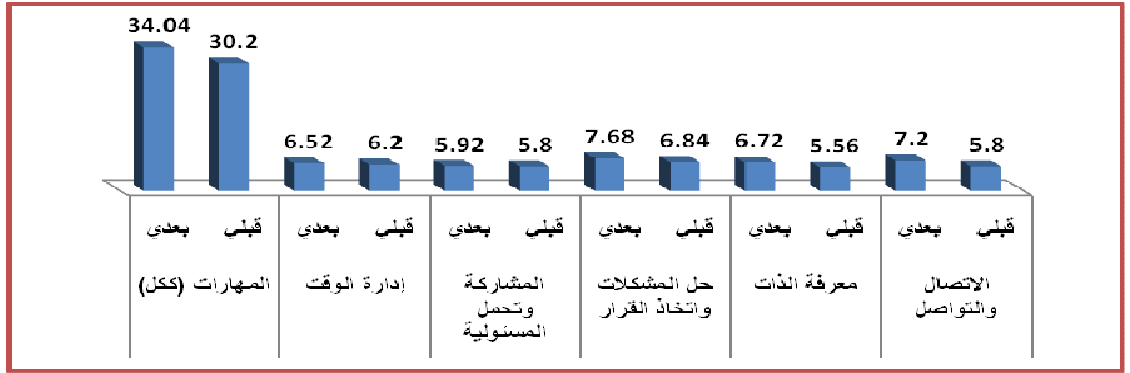

شكل (7) متوسط درجات طالبـات المجموعة الضابطة ِِّ التطبيقين القبلي والبعدي علي بطاقة ملاحظة المهارات الحياتية (ككل) ومهاراتها الفرعية.

الثرض السابع

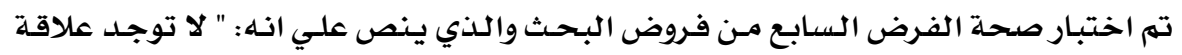

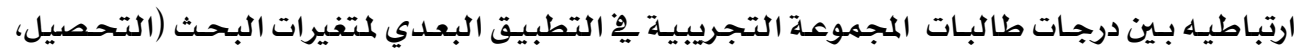

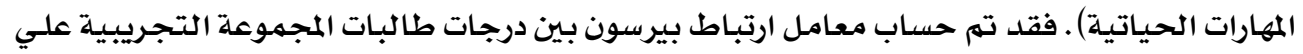

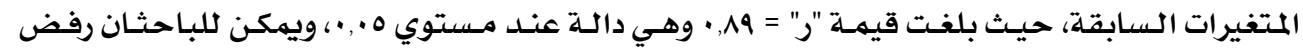

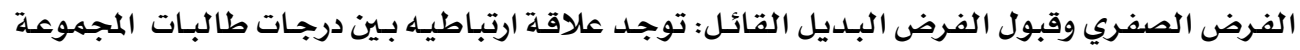

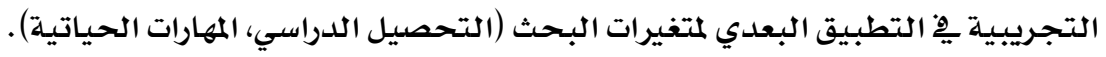

بحث فعالية الاستراتيجية المقترحة:

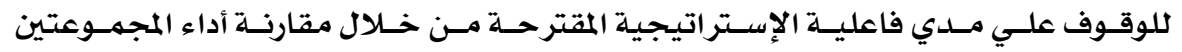

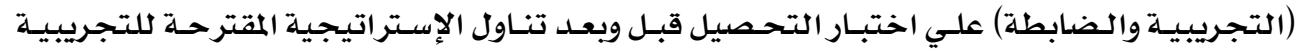

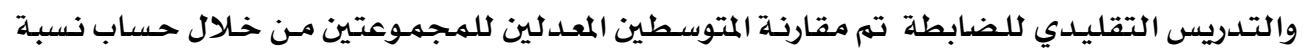

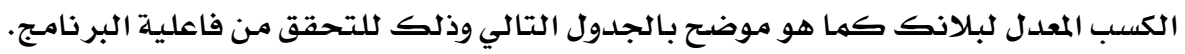
جدول (rا ) متوسط درجات المجموعتين التجريبية والضابطة يِ التطبيق القبلي والبعدي لاختبار التحصيل

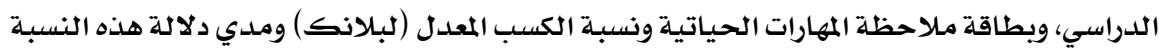

\begin{tabular}{|c|c|c|c|c|c|c|}
\hline مدي القبول & نسبة الكسب & |النهاية العظمي & المتوسط & التطبيق & المجموعة & الاختبار \\
\hline \multirow{2}{*}{ مقبولة لأنها أكبر من الواحد } & \multirow{2}{*}{$1, r$} & \multirow{4}{*}{7.} & rr,0T & قبلي & \multirow{2}{*}{ التجريبية } & \multirow{4}{*}{ التحصيل الدراسي } \\
\hline & & & $0 \cdot, \leqslant \Lambda$ & بعدي & & \\
\hline \multirow{2}{*}{ غير مقبولة لأنها أقل من } & \multirow{2}{*}{ - 1 . } & & $r q, r r$ & قبلي & \multirow{2}{*}{ الضابطة } & \\
\hline & & & $70, r 7$ & بعدي & & \\
\hline \multirow{2}{*}{ | مقبولة لأنها أكبر من الواحدا } & \multirow{2}{*}{$1, \times 9$} & \multirow{4}{*}{ vo } & $r r, Y \xi$ & قبلي & \multirow{2}{*}{ التجريبية } & \multirow{4}{*}{ بطاقة ملاحظة المهارات } \\
\hline & & & $r 0, \cdot \xi$ & بعدي & & \\
\hline \multirow{2}{*}{ غير مقبولة لأنها أقل من الواحد الصحيح } & \multirow{2}{*}{ • $1 \xi$} & & $r \cdot, r \cdot$ & قبلي & \multirow{2}{*}{ الضابطة } & \\
\hline & & & $r \xi, \bullet \xi$ & بعدي & & \\
\hline
\end{tabular}


يوضـح نتائج الجدول السابق نسبة الكسب المعدل لبلانك، حيث وجد أن نسبة الكسب المعدل

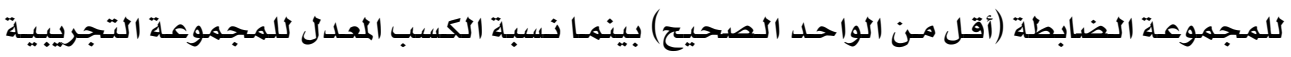

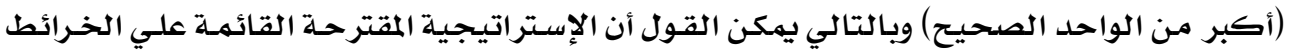

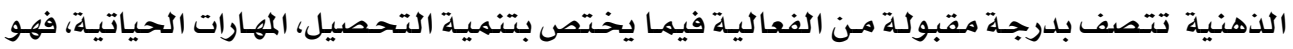

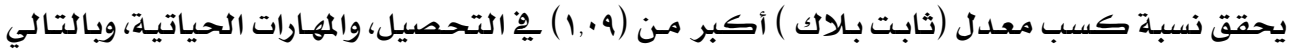

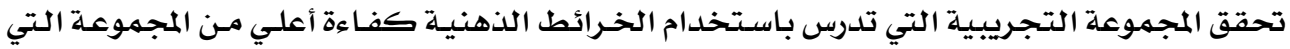
تدرس بالنهط التقليدي. تعقيب الباحثين علي فروض البحث:

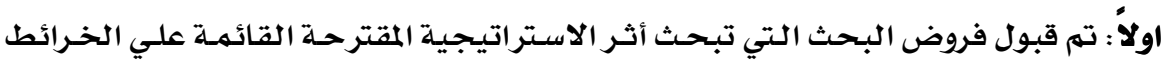

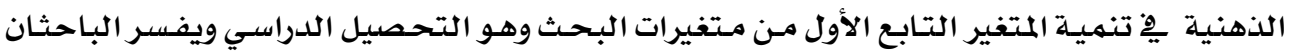

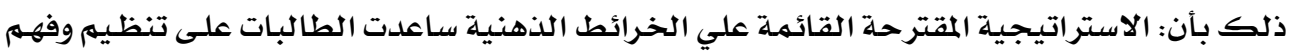

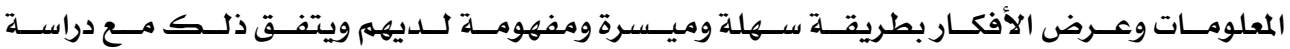
(Holzman,S.,2004)، فضلا علي تنمية القدرة على التـذكر واسـترجاع المعلومـات وإيجـاد الحلـول

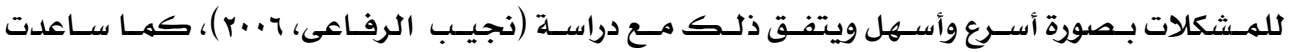

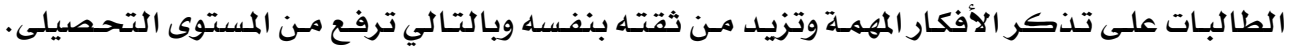

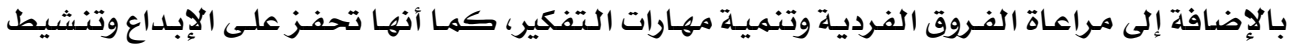

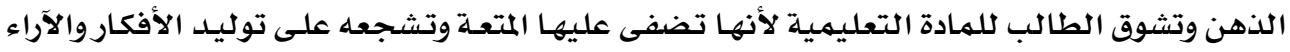

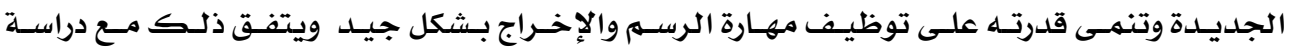

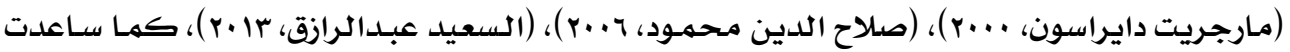

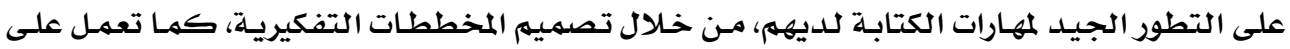

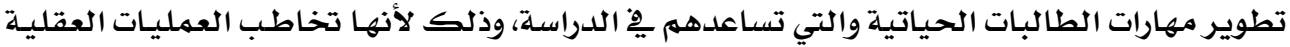

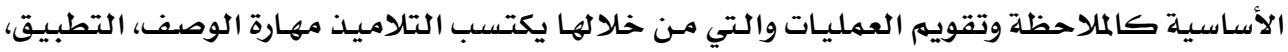

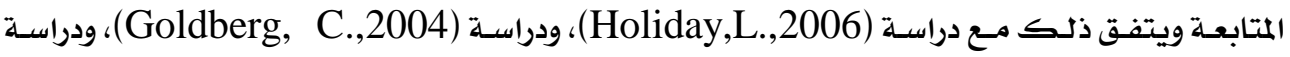

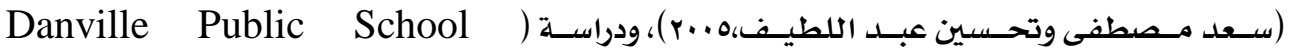

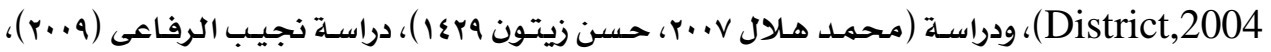

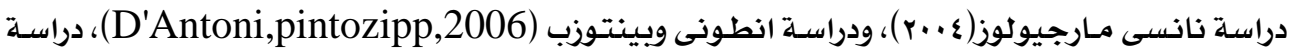

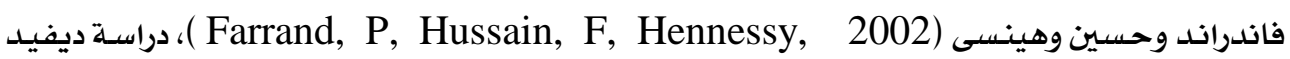

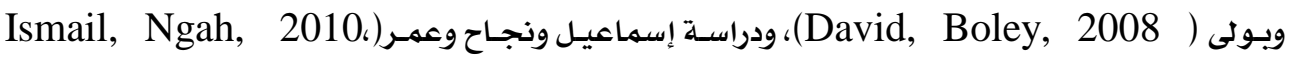

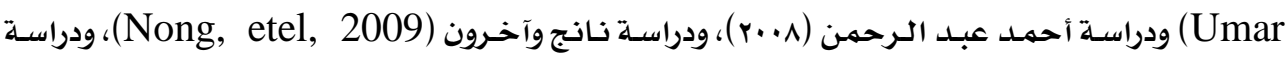

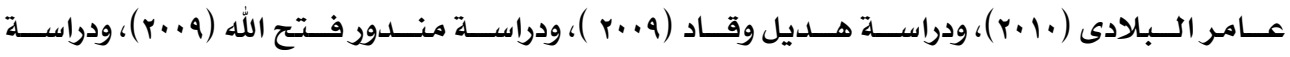

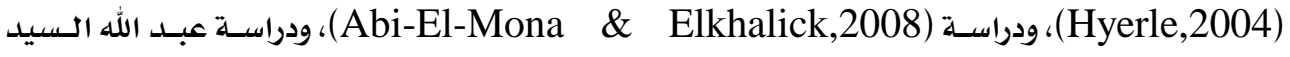

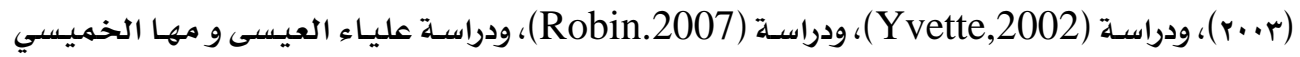




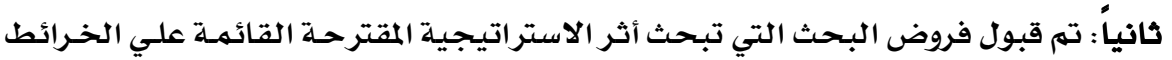

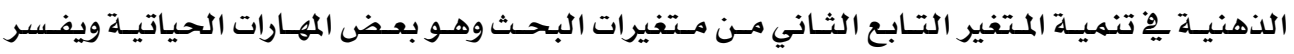

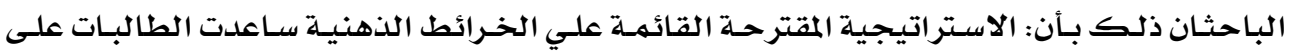

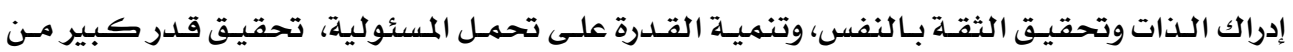

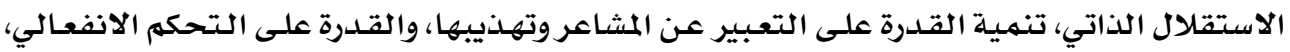

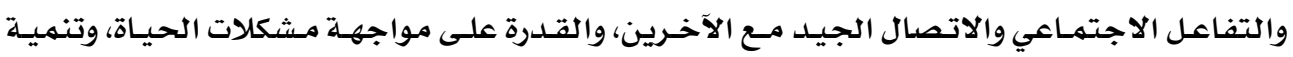

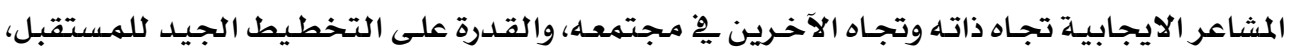

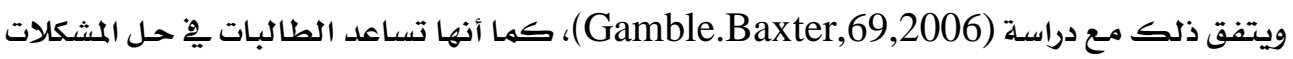

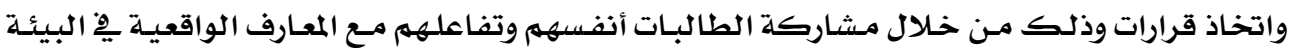

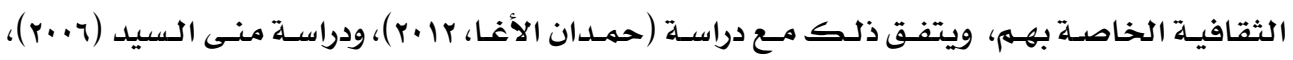

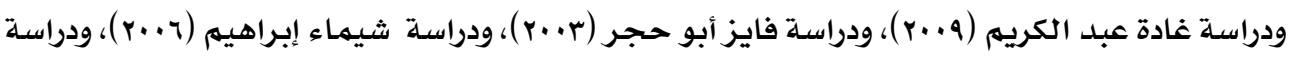

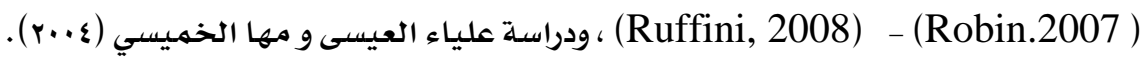

هِّ ضوء النتائج التي توصل إليه البحث الحالي يمكن التوصية بما يلي:

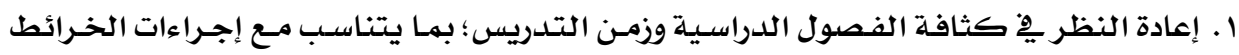

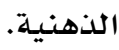

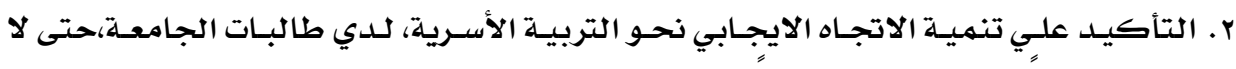
يحدث قصوراً من دراستها مستقبلاً.

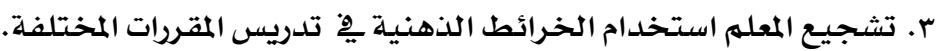

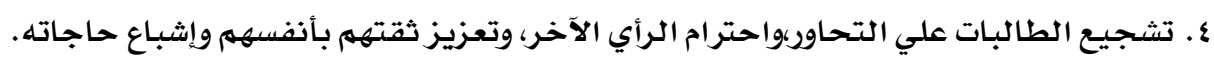

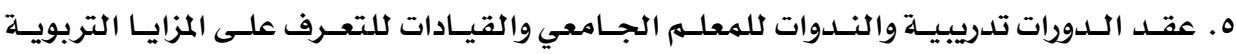

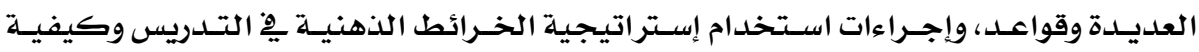

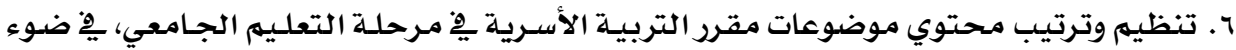

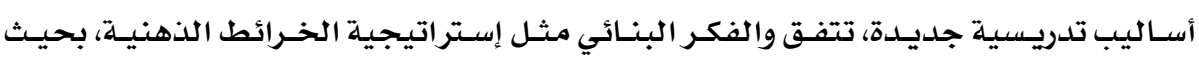

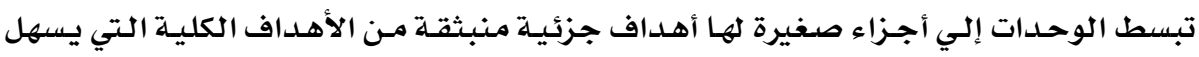

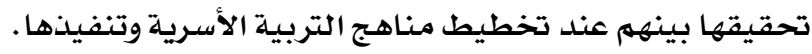

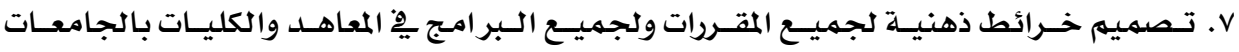
المصرية. 


\section{الدراسات والبحوث المقترحة:}

هٌِ ضوء نتائج البحث الحالي يمكن اقتراح بعض البحوث المستقبلية التالية: ا ـ دراسـة أثر إستراتيجية الخرائط الذهنية علي تعديل التصورات البديلة لدي طالبات الجامعـة.

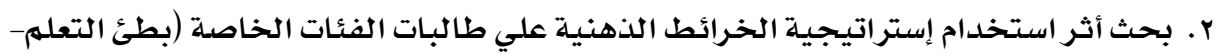

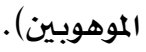

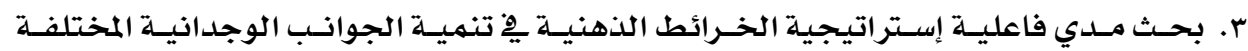

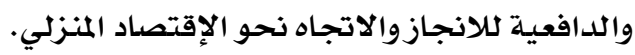

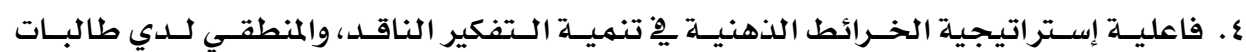
الجامعة.

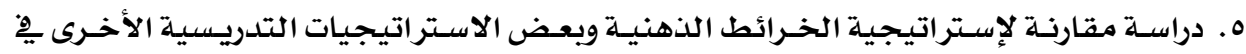

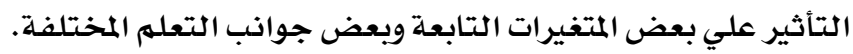

\section{أولاً المراجع العربية: أمراجية}

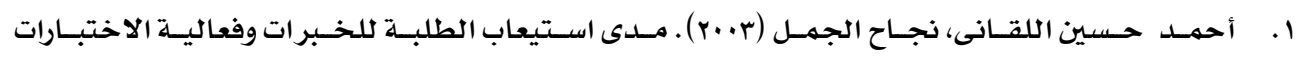

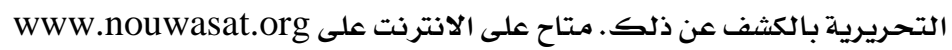

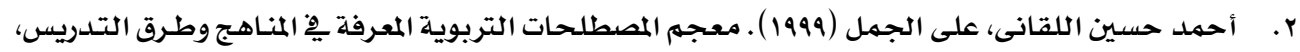
القاهرة: عالم الكتب.

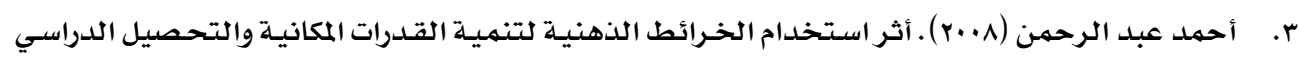

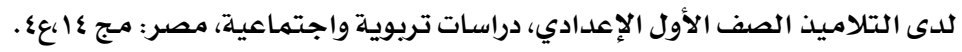

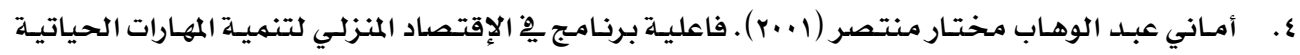

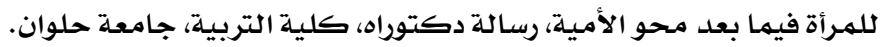

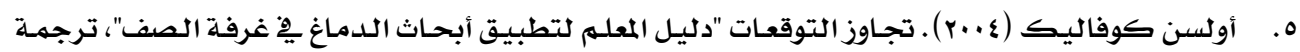

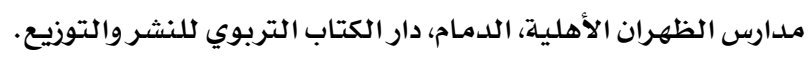

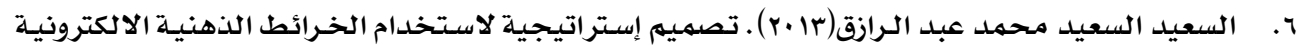

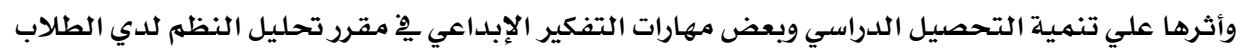

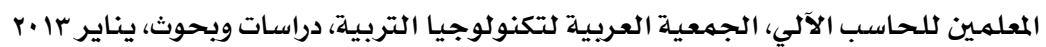

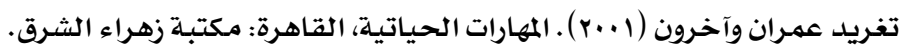

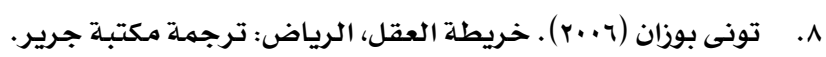

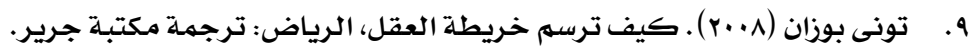

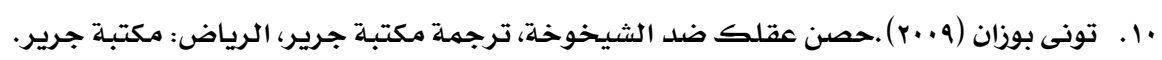

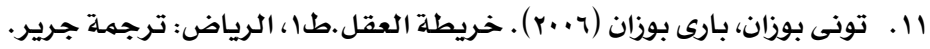

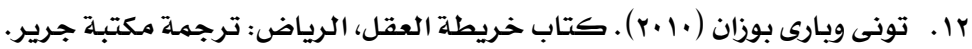


rا. حسن حسين زيتون (1) (1) ). تنمية مهارات التفكير، الرياض، الدار الصولتية.

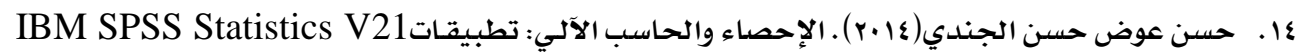
مكتبة الأنجلو المصريـة، القاهرة: الطبعة الأولي.

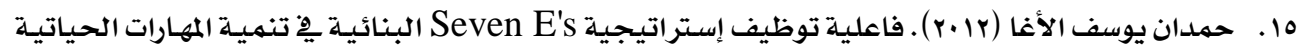

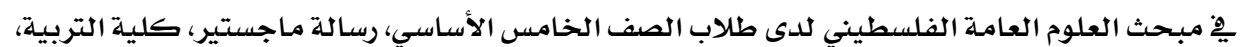

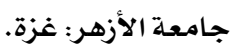

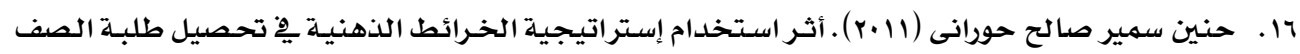

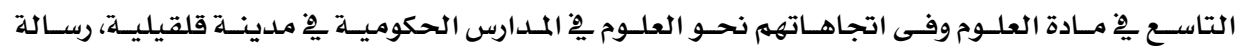

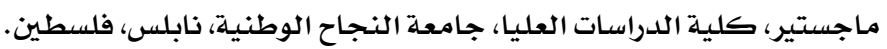

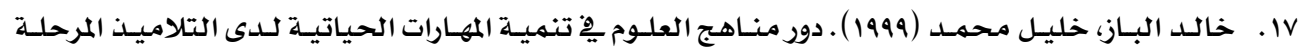

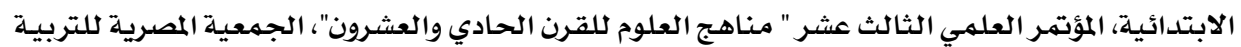

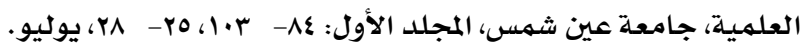

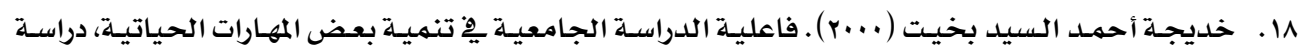
ميدانية على طلاب بعض كليات جامعة حلوان، المؤتمر القومي السابع، كلية التربية الجاتية.

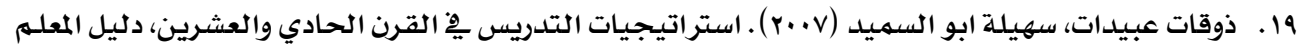

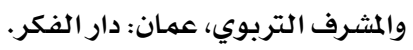

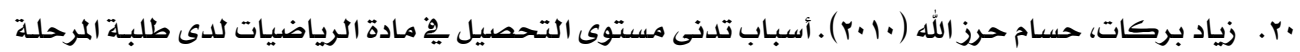

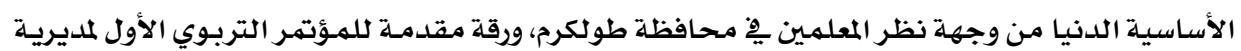

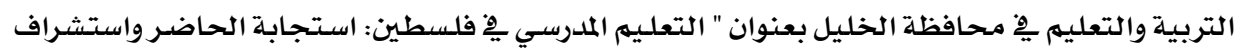
المستقبل ". اY. . سعد مصطفى وتحسن عبد اللطيف (0.r). دليل المعلم إلى تنميـة مهارات التفكير، الرياض: مطبوعات مدارس الملك فيصل.

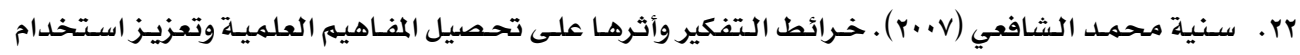

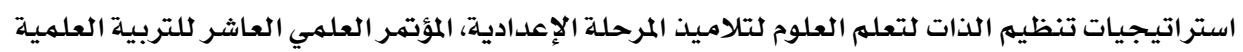

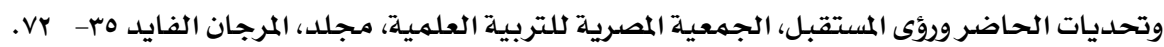

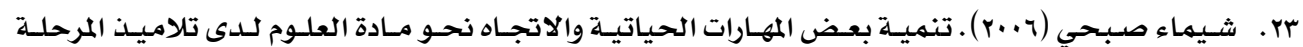

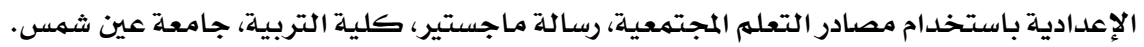

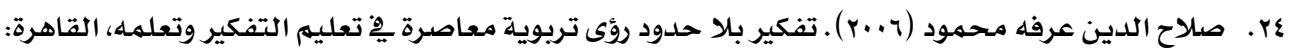

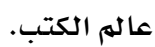

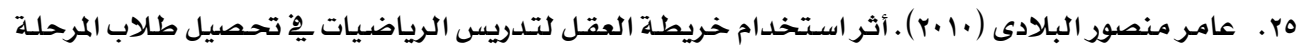

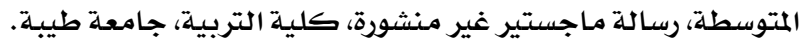

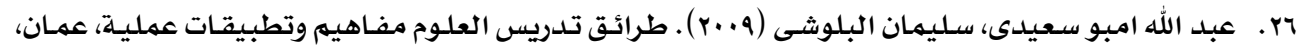
الأردن، دار المسيرة للنشر والتوزيع. 


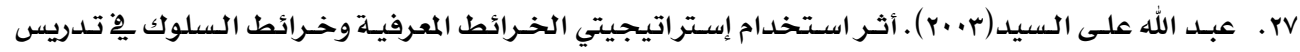

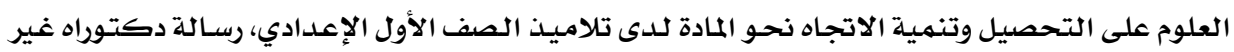
منشورة، كلية التربية، جامعلة عين شمس.

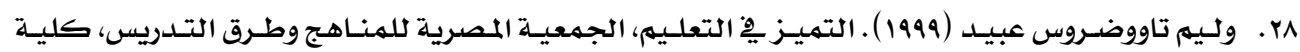

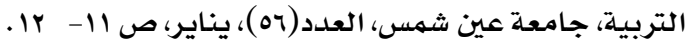

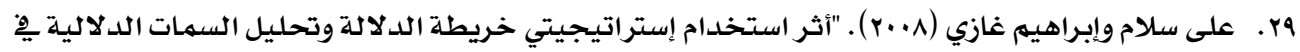

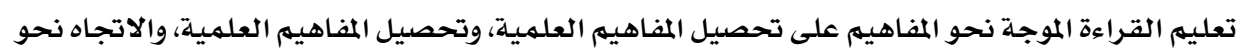

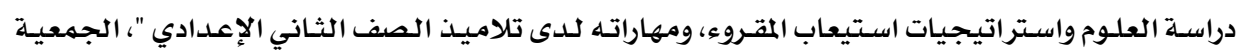

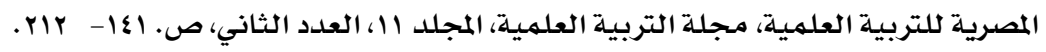

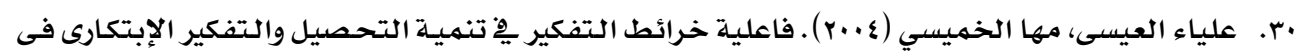

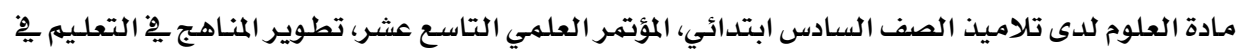

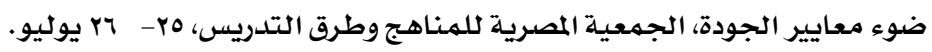

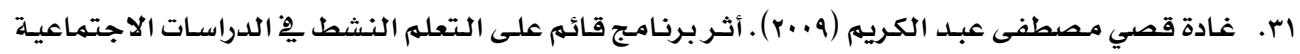

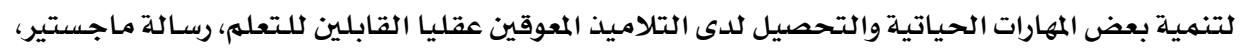

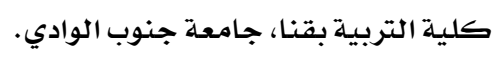

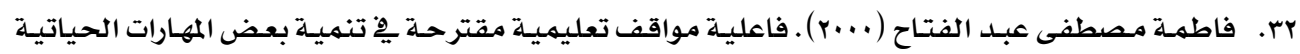

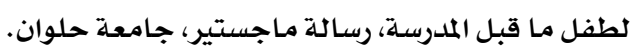

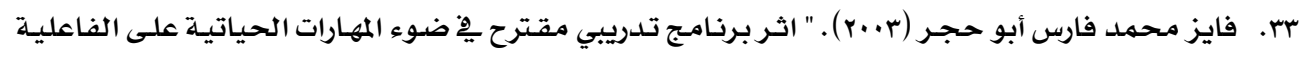

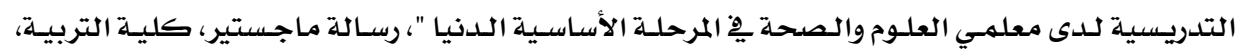
جامعة عين شمس.

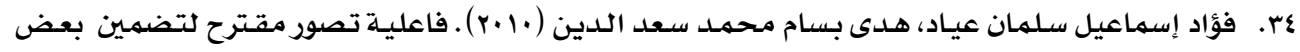

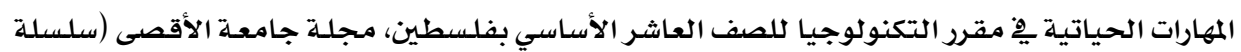

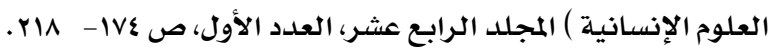

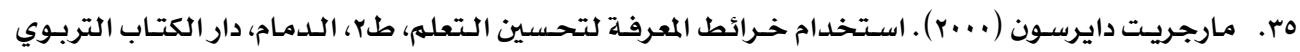

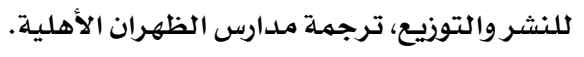

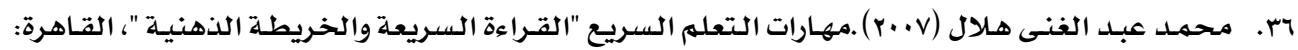
مركز تطوير الأداء والتنمية.

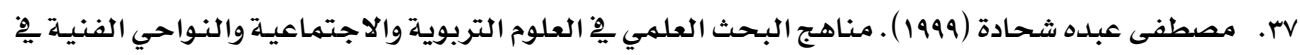

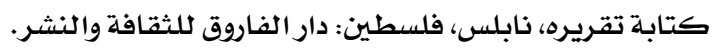

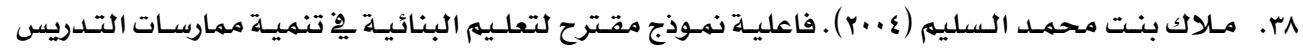

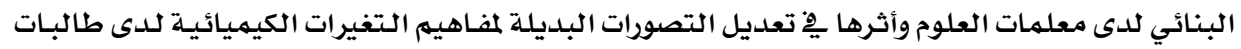

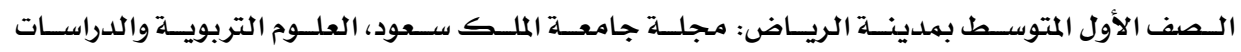

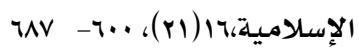




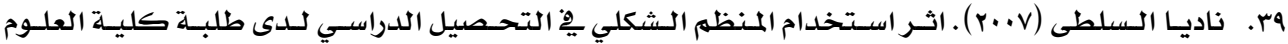

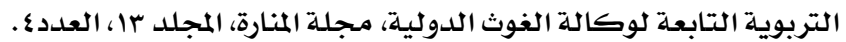

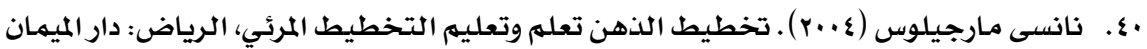

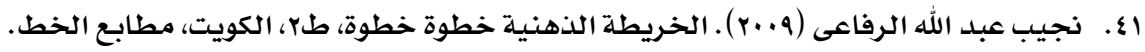

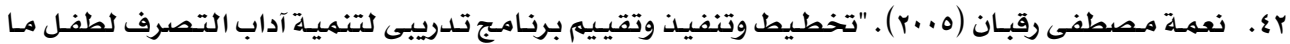

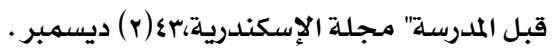

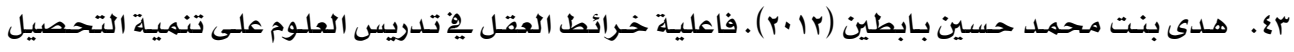

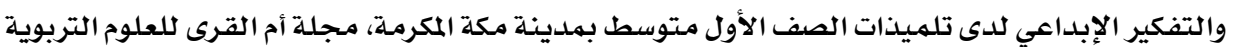

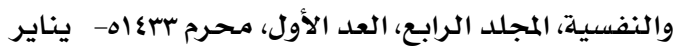

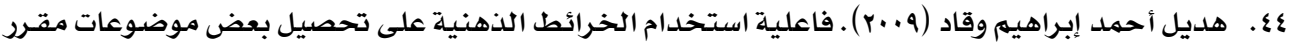

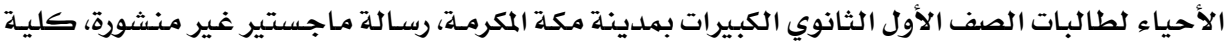
التربية جامعة أم القرى، المملكة العربية السعودية.

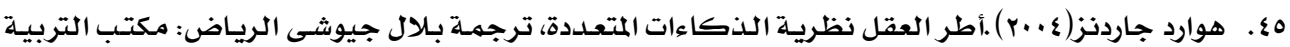
العربي لدول الخليج.

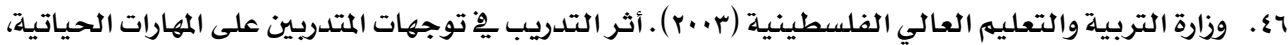
وزارة التربية والتعليم العالي برام الله.

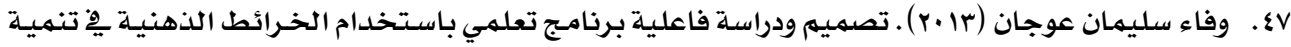

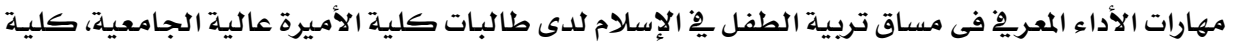

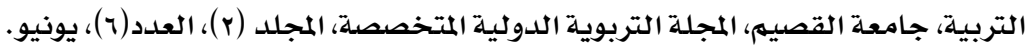

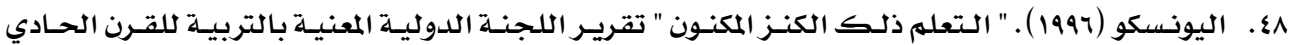

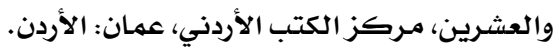

ثانياً: المراجع الأجنبية:

49. Abi-Elmona \& Elkhlick (2008): "The in Flounce Mind Mapping on Eighth Grader' Science Achievement". Journal Articles, School Sciencev and Mathematics, vq08n7 p298-312. Nov.

50. Ausbel, D.P.(1962).Asubsumption theory of meaningful verbal learning and retention.Journal Of General Psychology.66,213-224

51. Ausbel, D.P.(1968).Educational Psychology:Acogitive View.NewYork: Holt, Rinehart And Winston.

52. Buzan, T (2003) How to mind map, London: BBCWorldwide,LLB150BUZ

53. Buzan, T.(2007) The Buzan Study Skills Handbook: The Shortcut to Success in Your Studies with Mind Mapping, Speed Reading and Winning Memory 
Teachniques (Mind Set), BBC Activ,an imprint of Educational Publichers LLP, Harlowm Essex CM20JE,England

54. Buzan, T.(1977): Making the Most of your Mind Pan Books BBC Active, an imprint of Educational Publishers LLP. Harlowm Esse

55. Buzan,T(1993) The Mind Map Book Radiant Thinking London: Butler\& Tanner, BBCActive, an imprint of Educational Publishers LLP, Harlowm Essex CM20JE,England

56. Buzan,Tony.(2006).Mind Mapping Kick Start Your Creativity And Transform Your Life.Spin,Mateu Cromo

57. Cannela,G.:Reiff,J. (1994). Individualconstructivistteacher education teacher's as empowered learners. Journal Of Teacher Education Quarterly,21(31),27-28.

58. Danville Public Scool District (2004): " Thinking Maps,". us/dps/instrucationthinkings maps.html www.web.dps.k12-.va

59. Farrand, P, Hussain, F, Hennessy, E. (2002): The efficacy of the mind map study teachique.Journal Of Medical Educational,36 (5), 426-431.

60. Gamble.Baxter(2006)."teaching life skills for stutent for stutent success,2p, Available at:Eric/ journal articles/

61. Goldberge,c.(2004): " Brain Friendly Techniques:Mind Mapping "ScoolLibraryMediaActivities Monthly,V.21,NO.3.

62. Holiday,L.(2006).:Thinking Maps, holly Tree Elementary Scool" www.nhcs.k12.nc.us/tree curriculum/ thinking maps.html

63. Holzman,S.(2004): "Thinking Maps: Strategy-Based Learning for English Language Learner and Other ",Annual Administrator Conference 13th Closing the Achievrment Gap for Education Learner Student. Sonoma Country Office of Education. California Department of Education.

64. Ingemann, Bruno (2002) Nordisk Museologi/1,SUMMARY pp.31-48

65. Ismail, Mohd Nasir, Ngah, Nor Azilah, Umar, Irfan Naufal (2010): The effects of mind mapping with cooperative learning on programming performance problem solving skill and meta computer science students. Journal of Educational Computing Research, 42 (1), 35-61.

66. Jensen.E.(2000).Learning with brain in mind San Dlieo.CA:The Brain Store. 
67. Lim,S., (2003):Developing Reflective and Thinking Skill Means of Semantic Mapping Strategies in Kindergarten Taecher Education " Early Child Development and Care,173.(1)

68. Margulies,N.\&Valentza,C,(2005):Visual Thinking:Tool ForMapping Your Idea,Grown House Pub.

69. Montgomery, H(2005): Literature Review And First Attempts at the Teaching Mind Mapping In a Grade 3 Class.http//instructional lintelligence.net/downloads/Montgomery\%202005_Literature\%20Review\%,r2 0Mind\%Mapping.pdf.

70. Nong, B. \& Pham,T.\& Tran,T.(2009): Interate the Digital Mind mapping into Teaching and Learning Pschology http://www.unscobkk.org/fileadmin /usr_upload/apeid/Conferece/13th_Conferece/

Papers/4.E.3_Integrate_digital_mindmapping_in_Psychology_VVOB_.pdf

71. Robin, M.(2007) Cooperative Learning and mind map: Keys that teach All students to Think. International Con Terence.thinking Maps.13-14 july In coepoate.

72. Ruffini,M. (2008): Using map to organize and Naviqat online content.EDUA cause CASUSE, Quarterly, v.31 N1.p56-61.

73. Sander,s R and Kajs, L. (2002): Electronic Mapping in Education:The use of Geographic information systems,Journal of Research on Tachnology in Education,34 (2), p.p 121-129.

74. Sylvia, P. (2007): Thinking Maps Through The Eye of Scoole Leader, International Conference, Thinking Maps, 13-14 July, Incorporated.

75. Wikipedia,S. (2007): " Cognitive Maps ". www. Wikipedia.Org

76. Wisconsin deparment of public instruction, Career and teachical education team, (2006).Career \& Technical Education, www.dpi. state.wi Us/ 25-3-2008

77. Wycoff, J(2010) Mindmapping in 8 Easy Steps, CEO, Thinksmart, Inc. and author of Mindmapping: Your Personl Guide to Exploring Creativity and Problem-Solving, available online at 6/may/2010 http://www.thinksmart.com/2/articles/mindmapping.html

78. Yvette,j.(2002): Closing the Gap by connecting cutture language and cognition,Ed.D,National Urban Alliance. 58-59. 


\section{Design Strategy Based on The Mind Mapping And Their Impact on Academic Achievement And The Development Some of Life Skills; for Home Economics Students of Faculties of Specific Education}

Dr /Hassan Awad Hassan *
Dr / Samah Abdel Fattah Abdel ${ }^{* * *}$

\section{Abstract}

The goal of current research is to explore the impact of the use of mind maps strategy in the development of academic achievement, life skills and some of the female students of colleges of education quality issues are included in the decision of family education.

The study sample consisted of 50 students in the second semester 2012/2013 AD, were distributed into two groups, such as ; one experimental group of (25) students and other control group, and strength (25) students have researchers used the research method quasi-experimental based on the experimental design tribal dimensions of a control group, the researchers have been applying the topics scheduled in accordance with the strategy of mental maps ; through the teacher's guide prepared by researchers for it. They also apply the achievement test in the course to measure academic achievement and note card some life skills.

Has reached the search results to: the presence of a statistically significant difference at the level (0.05) between the mean scores of students in the experimental group pre and post the two applications, for the achievement test in the decision of family education, card and note some life skills.

Also found a positive correlation function between the scores of students in the experimental group achievement test and the note card Drjathen life skills

I recommend those who search the processes of teaching and learning strategy, attention mental maps, and workshops for training on their use in teaching.

Key words: "Strategy - Mind Mapping - achievement - life skills family education - students of faculties of specific education

Lecture Of Math And Applied Statistics. Faculty Of Specific Education Tanta University

Lecture of home management and institutions Faculty Of Specific Education Zagazig University 